\title{
THE POLITICS, POETICS, AND PERFORMANCE OF SPACE: THE SACRED SPACE OF COOK ISLANDS CHRISTIAN CHURCHES
}

\author{
BY \\ MARIA KECSKEMETI
}

\begin{abstract}
A thesis
submitted to the Victoria University of Wellington in fulfilment of the requirements for the degree of

Master of Arts in Anthropology
\end{abstract}

Victoria University of Wellington 


\section{Table of contents}
Abstract 3

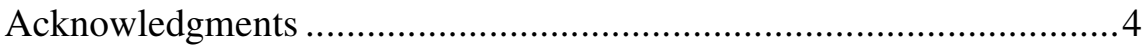

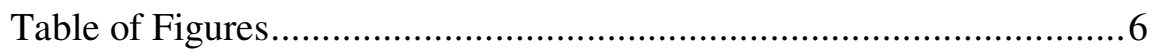

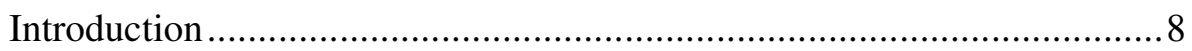
Literature on space and religion ................................................. 9
The Cook Islands and Christianity .................................................. 11
Research methods and methodology ............................................ 17
Theoretical Perspective: A spatial approach .....................................24
The politics of sacred space ..................................................25

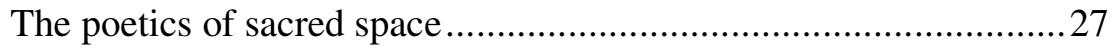
The performance of sacred space ...........................................28

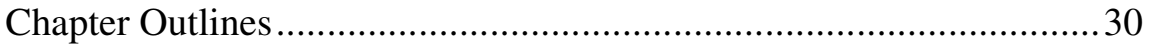

Chapter 1: The Politics of Space: Tradition, Modernity, and the Contest over

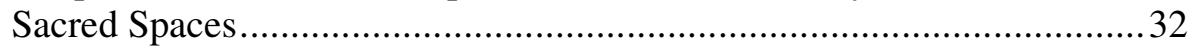

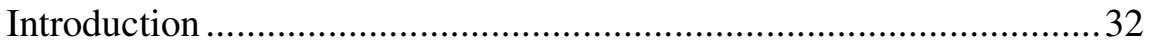

An April fool's day with no laughs: The destruction of the Avarua church

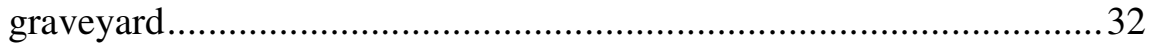

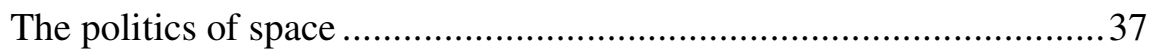

Contesting sacred sites: How should places be used and who controls

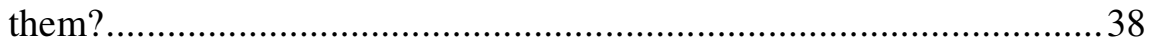

Constructing sacred sites: History and tradition is sacredness..............46

Changing sacred sites: When does beautification become desecration?51

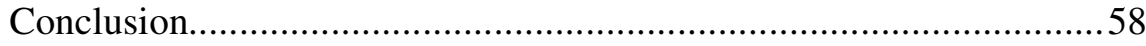

Chapter 2: The Poetics of Space: Social and Architectural Symbols of Sacred

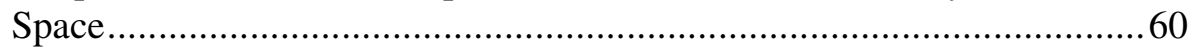

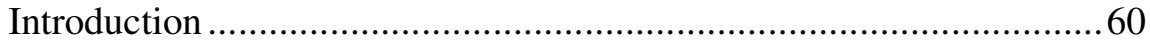

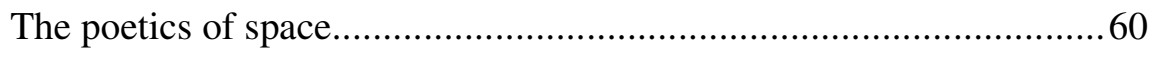

Architectural markers of sacred space: The materialization and ritualization of the sacred..............................................................61 
Social markers of sacred space: The production of sacred spatial orientations

Conclusion.

Chapter 3: The Practice of Space: The Spatiality of Performance and Performing Sacred Space

Introduction . 85

The Performance of Sacred Space ................................................... 86

Sunday worship: A ritual performance …........................................90

The spatiality of ritual performance ............................................. 91

Ritual performance of sacred space ...............................................99

Nuku: A theatrical performance .................................................. 96

The spatiality of theatrical performance ........................................99

Theatrical performance of sacred space ...................................... 100

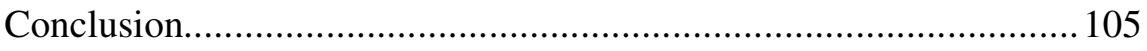

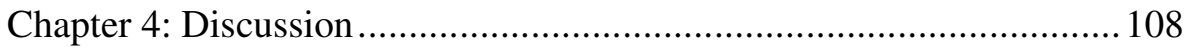

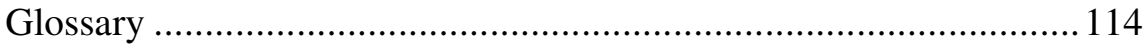

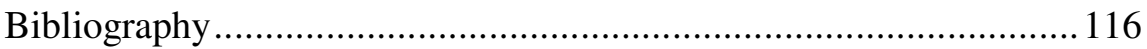




\begin{abstract}
The current literature about sacred space suggests that it is produced through either substantive definitions of space (the poetics of space) or situational definitions of space (the politics of space). I conducted ethnographic research in the Cook Islands to consider how these two constructions of space interact to produce the sacred space of the Cook Islands Christian Church. I have shown that the production of sacred space can be described through three modes of spatial production: the politics of space, the poetics of space and the performance of space. They are enacted through social practices in an inter-related process. Based on these findings I propose a spatial triad model. I suggest that by moving beyond traditional dichotomous constructions of space such a spatial triad model can contribute to new understandings of how sacred and profane space is produced and reproduced.
\end{abstract}




\section{Acknowledgments}

"As we express our gratitude, we must never forget that the highest appreciation is not to utter words, but to live by them." - John F. Kennedy.

In light of that quote, I will not go into long tangents about every person that helped me on this journey for the list would be too long. But there are a few who I would like to acknowledge because I feel I can never show them enough appreciation and thanks:

I am grateful to my supervisor, Jeff Sissons, who encouraged my ideas, who put up with my long-stewing and perfectionist writing process, and who helped with the translations in this thesis.

I am also grateful to the many people at Victoria University of Wellington especially my secondary supervisor, Brigitte Bonisch-Brednich for providing advice about methodology and fieldwork; the School of Social and Cultural Studies including the office ladies Alison, Carol, and Monica (who showed much patience and kindness); the rest of the SACS post-graduate students (many of whom have become good friends and who over the course of this thesis provided valuable advice, both academic and personal); and a special mention to my office-mate Marynia Grafin von Thun und Hohenstein, (who always managed to make the ups and downs of this experience a laugh).

I am very grateful to those who helped me with my research - to the leaders and members of the Cook Islands Christian Church for letting me admire and experience their faith and churches; to those who supported me and pointed me in the right direction while I was doing my field work - director Rod Dixon and the rest of the team at the University of the South Pacific, and Jean and Sally at the Cook Islands Library and Museum who helped me with archived newspapers; and finally to the wonderful people of Rarotonga who welcomed me, accommodated me, and aided me. 
Lastly, I am grateful to my friends and my family who encouraged and supported me throughout my thesis. In particular I wish to mention two people: first, my mother, who provided continuous feedback and who I could always rely on for a fresh perspective when I got bogged down in theory. Second, to my partner, who put up with my elation and frustration over the course of my research.

Just know I could not have done it with out you all.

M. Kecskemeti 


\section{Table of Figures}

Figure 1: The coastal side of the churchyard where the graves were destroyed. The Church is seen on the right. In the foreground, the damage caused by the bulldozer and subsequent repairs are visible on the left side of the wall 34

Figure 2: Clockwise from top left: A broken headstone leans against the left perimeter wall. More than five years later, a group of headstones near the front perimeter wall still lie on their sides. Two fallen headstones (detail). A broken headstone is leaned against two other headstones, one of which is also damaged.

Figure 3: A row of white painted headstones by the rear wall of the Avarua churchyard. There are no clear visible names on them. The front most grave on the left is an example of where the casing has collapsed. Graves with such collapsed casings are what the Avarua ekalesia wanted to remove. 48

Figure 4: The Ngatangiia church exterior (top) compared to the Arorangi church exterior (middle) contrasts the space available due to the lack of graves with the presence of graves in the church yard; Matavera church (bottom) is somewhat of an exception. There are graves on the right hand side but the left is an elevated lawn where the graves were covered with soil.

Figure 5: The two entrances in the boundary wall surrounding Avarua Cook Islands Christian Church. 66

Figure 6: The sign Ziona Tapu above the threshold of the Avarua Cook Islands Christian Church clearly marks the church as a sacred space

Figure 7: (Top) Pulpit at Avarua church in detail; (below) the pulpit at Ngatangiia church. Both are representative of the general configuration of churches on the island with a high pulpit from which the orometua preaches, and a lower pulpit or lectern which lay people (i.e. deacons, women, and youth) may use to read scriptures, lead the ekalesia in prayer, or to make general announcements.

Figure 8: Diagram of Avarua Cook Islands Christian Church floor plan illustrating socio-spatial divisions. On the ground floor, ariki sit near the pulpit on the left side while mataiapo sit on the right. The rest of the space is divided according to sub-districts. The upper floor is where youth and foreigners sit (Field notes, April 2010). 72

Figure 9: A view of Avarua church from the upper level. As this photo shows, the pulpit is clearly visible even from the upper level of the church.75

Figure 10: Diagram of sacred spatial and behavioural orientations. 78

Figure 11: Pictured is the Sinai Hall which is used for youth services and contemporary forms of worship. It is located to the left and outside the boundary wall of the Avarua Cook Islands Christian Church. 78 
Figure 12: Diagram of sacred/profane spatial orientations in the Cook

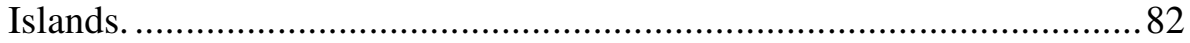

Figure 13: The performers from each CICC ekalesia line up before the ariki and mataiapo before the Nuku pageant begins. 98

Figure 14: One of the props used at the 2010 Gospel Day celebrations. Performers wait as a boat with a "heathen" is pulled along the sports field. The boat shows the journey of Cook Islands missionaries who spread the gospel to the South Seas. 99

Figure 15: Hula dancing is performed in one of the Nuku plays at the 2010 Gospel Day celebrations. The dancing symbolised the journey of a missionary to and from different Pacific islands. 101

Figure 16: Diagram of spatial distinctions at Gospel Day (Nuku pageants). (Field notes, October 2010) 102

Figure 17: Diagram of performances in correlation to spatial and behavioural orientations. 106

Figure 18: Diagram of modes of spatial production 110

Figure 19: Diagram of modes of spatial production in the Cook Islands 111 


\section{Introduction}

The title of Howard Henry's book "Christianity created a Nation" (2003) is a particularly apt summary of the history of the Cook Islands. The Cook Islands are a Polynesian nation located in the Pacific Ocean comprised of fifteen islands which are geographically divided into the northern group of Penrhyn (also known as Tongareva), Manihiki, Pukapuka, Rakahanga, Nassau, and Suwarrow and the larger southern group of Rarotonga, Mangaia, Atiu, Mauke, Mitiaro, Aitutaki, Palmerston, Manuae, and Takutea (Gilson 1980; Sissons 1999). It was to these islands that the London Missionary Society came in 1821 and, within the space of less than two years, converted the inhabitants of most southern islands to Christianity. This rapid social transformation was materialized, embodied, and symbolized through the building of churches; grand structures whose scale and likeness had never been achieved before in the Cook Islands. However, they were more than just magnificent buildings: these "Churches at the centres of Christian settlements were physical spaces in which relations between ariki, priests and people were practised and conceptualized in new ways" (Sissons 2007: 57). But one hundred and ninety years later, what do these churches represent and embody today? How are these physical spaces of the church conceptualized? And in what way are the social relations between traditional leaders, priests and people practised and embodied in these places?

My interest in Rarotonga as a site for research was first piqued by a review of the Cook Islands, which mentioned that in 2003 underlying conflicts had developed between church leaders and landowners. The new pastor of the Avarua Cook Islands Christian Church (CICC) on Rarotonga had followed a policy of knocking down old gravestones with a bulldozer to 'beautify' the church grounds. The landowners and descendants of those buried there expressed anger at the action and even took the pastor and deacons of the church to court (Jonassen 2004). With an established interest in the agency of material culture (Gell 1988; 1998; 1999) this event caused 
me to question the ways in which people interact with their built environment: were the meanings and reactions to this event rooted in social and cultural norms or was there something inherent about the building and space itself which mediated the responses? In other words, the issue this thesis addresses can be stated as follows: 'in what manner do social constructions and subjective constructions of space interact to produce the religious space in the Cook Islands?'

\section{Literature on space and religion}

Religion and space have long been topics of interest for multiple disciplines: from the anthropology of religion first discussed by E.B. Tylor and James Frazer, which blossomed into a vast field focusing on the symbolism and psychological aspects of religion as well as structural, political and comparative aspects (Arweck \& Keenan 2006; Bennett 1996; Cannell 2006; Eller 2007; Lambek 2008); the relatively recent postmodernist anthropology of space which has looked at the relationship between the built environment, cultural processes and human behaviour (Ingold 2009; Kokot 2006; Lawrence \& Low 1990; Low \& Lawrence-Zúñiga 2003; MacDonald 2003); to that of sociology, history, and religious studies (Brown 2004; Davies 2003; Evans 2003; Jones 1993, 2000; Lefebvre 1991), cultural geography (Soja 1980; Warf \& Arias 2009) and in particular the subfield of geography of religion (Brace et al 2006; Corrigan 2009; Henkel 2005; Knott 2005a, 2005b; Kong 1990, 2001, 2010; Yorgason \& della Dora 2009). Understandably then, the attention in the literature to the topic of space and religion has been diverse although somewhat neglected as a specifc topic.

Within Oceania, there has been limited attention to space and religion together (but see, for example, Tomlinson 2002; Toren 1988, 2006). The literature on space in the Cook Islands has focused on the pre-Christian dichotomies of spatial organisation (Campbell 2002a, 2002b), the expression of traditional Rarotongan and Pacific Island cosmologies (Siikala 1991; 
Sissons 1989), and the transformation and materialization of new "social fields" during the conversion to Christianity (Sissons 2007: 49).

Most of the literature that addresses both space and religion follows two divergent approaches (Kong 2001, 2010). On the one hand, the poetics of space views the landscape as something upon which the sacred is expressed or which sets apart the landscape into the sacred and the profane. This is phenomenological in its approach. On the other hand the politics of space views changes to the landscape as the result of particular social structures being imposed upon the landscape. This is social constructionist in its interpretation (Kong 2001, 2004). Chidester and Linenthal (1995) succinctly summarise this distinction as follows:

Familiar substantial definitions - Rudolph Otto's "holy," Gerardus van der Leeuw's "power," or Mircea Eliade's "real" - might be regarded as attempts to replicate an insider's evocation of certain experiential qualities that can be associated with the sacred. From this perspective, the sacred has been identified as an uncanny, awesome, or powerful manifestation of reality, full of ultimate significance. By contrast, however, a situational analysis, which can be traced back to the work of Emile Durkheim, has located the sacred at the nexus of human practices and social projects. ... As a situational term, therefore, the sacred is nothing more nor less than a notional supplement to the ongoing cultural work of sacralising space, time, persons, and social relations. Situational, relational, and frequently, if not inherently, contested, the sacred is a by-product of this work of sacralization." (Chidester \& Linenthal 1995: 5-6) ${ }^{1}$

However, while there is ample literature about the politics and poetics of space, a number of scholars have pointed out that religious spaces should be understood as more than just dichotomies of space vs. place, sacred vs. profane, concrete vs. symbolic, and poetics vs. politics. They call for the development of new understandings of space and place (Brace et al 2006; Holloway \& Valins 2002; Kong 2001). As a result one of the emerging trends that has developed in religion and space is the notion that space is a social product produced through social and religious practice. (Brace et al 2006;

1 For further description of Mircea Eliade and Emile Durkheim's concepts of the 'sacred', see Evans (2003) and Stirrat (1984). 
Holloway 2003; Knott 2005a, 2005b; Kong 2001; MacDonald 2002; Shiner 1972; Wilson 1993). In other words, spaces are a "practiced place" (de Certeau 1984: 117), (re)produced not only through the (built) environment but also through experience, movement, embodied actions, and performance (Holloway \& Valins 2002; Low \& Lawrence-Zúñiga 2003). This discourse about spatial practice and performance is what I shall develop in this thesis.

\section{The Cook Islands and Christianity}

Oral tradition states that the ancestors of Rarotonga came from Tahiti and Samoa in the thirteenth century, although it was already populated by people from the Marquesas (Gilson, 1980). I shall not go into much detail about the legend of Tangiia and Karika as there are varying accounts which have been written about it elsewhere (Maretu \& Crocombe 1983; Rere 1982; Sissons 1989; Williams 1837), but in short Karika, a great warrior chief from Samoa, first discovered Rarotonga in his travels. He later set out to sea where he met Tangiia who was fleeing from his brother, Tutapu the 'relentless pursuer', for a previous transgression in Tahiti. Fighting broke out between the two canoes until a covenant was reached between Karika and Tangiia. From there Tangiia proceeded on to Rarotonga where he first "made a circuit of the island, constructing marae, dedicating them to gods, and appointing guardians" (Sissons 1989: 338) before settling on the eastern side of the island. Karika later returned and settled on the northern side of the island. The political structure of tapere (sub-districts), marae (traditional meeting and sacred places), ariki (paramount chiefs), mataiapo (sub-chiefs), and rangatira (minor-chiefs) continues to follow that laid out by Tangiia (Rere 1982). In addition, the tribal genealogy today is derived from these two original ancestors: the descendants of Karika becoming Ngati Karika (the three modern titles being Makea Nui, Makea Karika and Makea Vakaatini), and the descendant of Tangiia becoming Ngati Tangiia. A third tribe descends from Tinomana Napa who was once the ruler of the Tangiia tribe. He was usurped by two mataiapo and banished from the Takitumu district to the western side of the island. Tinomana therefore became the ariki of the 
western district of Arorangi while the two mataiapo became the ariki of Takitumu (Pa Ariki and Kainuku Ariki) (Campbell 2002a, 2002b; Henry 2003; Rere 1982).

Although Europeans such as Captain Cook and traders had made contact with Cook Islanders, it was not until 1821 that the London Missionary Society missionaries first stepped on to Cook Islands soil. The missionary John Williams, with the two Raiatean teachers Papehia and Vahapata, first arrived at Aitutaki on October $26^{\text {th }} 1821$. The two 'native missionaries' (orometua) were left there and in fifteen months the island had been converted to Christianity. It was also here that Papehia and Vahapata found four Rarotongan women, two of whom, Tepaeru-Ariki and Mata Kavaau, were high ranking women related to ariki. The women had earlier been abducted by the crew of the "Cumberland", a European sandalwood expedition party. Two other Rarotongan men were also on Aitutaki, their canoe having been put off course during a storm (Henry 2003). Unbeknownst to the orometua these people would soon become invaluable to the conversion process on Rarotonga ${ }^{2}$. In 1823 John Williams returned to Aitutaki and learning of Rarotonga he, along with a band of missionaries, set out to find it so that they could preach the Gospel there ${ }^{3}$. When the London Missionary Society eventually landed on Rarotonga the attempt to teach the Gospel was not as favourable as initially thought and John Williams decided to leave and continue elsewhere. However, Papehia offered to stay on in

2 Tepaeru-Ariki was invaluable to the conversion process in Aitutaki, as when she was dropped there, she told the people of the useful possessions and wealth that the Europeans had. Because it was the belief that the traditional gods created and provided everything which existed in the universe "these European God or Gods appeared to be not only more prosperous, but also more powerful given that the ships these gods provided were significantly bigger than those canoes that the traditional gods had given to the people living on the island. As a result of this perception, the "seeds" of Christianity were firmly planted on the island with the view taken that the European God or Gods were so kind to their subjects, that it made the traditional gods of Aitutaki appear rather inferior, less powerful and far less generous." (Henry 2003: 17).

3 It was on this journey that John Williams made both unsuccessful attempts at conversion in Mangaia, as well as successful attempts at Atiu, Mauke and Mitiaro. The conversion of these latter islands was very rapid: the ariki of these three islands, Rongomatane Ariki, listened to the missionaries and then instructed each of his people to burn their marae and idols, to build a house of worship and to take care of the missionaries left behind and to accept what they taught (Rere 1980). So Christianity was accepted without any resistance as the ariki had ordered the conversion process. 
Rarotonga ${ }^{4}$ and he is largely considered responsible for the conversion to Christianity among the chiefs. He was soon joined by another orometua and a few years later the mission passed to the hands of European missionaries, including the influential Reverend Pitman and Reverend Buzacott (Henry 2003; Lange 1997; Garrett 1985; Rere 1980).

These early pastors faced many challenges. As a minority group, the religious converts created a Christian settlement at Avarua, and later Ngatangiia, where they received religious instruction. However, the presence of different tribal groups in one place meant that the pastors had to navigate the separate political factions to ensure that the early church remained strong (Henry 2003; Rere 1980). While the ariki and mataiapo ordered their marae and idols to be burned they initially only made up a small portion of the religious converts. There were mataiapo who did not want to hand over their idols and who actively opposed the orometua and new Christian order, including by destroying property at the new Christian settlements (Henry 2003; Rere 1982; Sissons 2007). Moreover, while the converted ariki and mataiapo supported the early church they still maintained some of their traditional pre-Christian customs enabling them to straddle the line between traditional life and the modernist tides of change. Over the course of a few decades, through the work of the missionaries and the transformation of social norms and structures, the non-converted Rarotongans eventually embraced Christianity.

If we look more closely at this transition to Christianity, it is clear that it occurred through the transformations and materialization of particular social fields (Sissons 2007). Firstly, the missionaries reinforced the acceptance of the new moral order by also changing the social order of control. For instance, 'Mission Laws' were created to regulate the lives of the church's followers in accordance to Christian principles (Gill 1856; Rere 1982). It was even enforceable by a judicial system although this was largely

4 John Williams only agreed to this plan when he had secured the word of the Rarotongans found on Aitutaki that they would look after Papehia. Makea had also agreed to give Papehia protection (Garrett 1985). 
controlled by the pro-Christian ariki who used it to enhance their political position within the community. The ariki were not immune to the 'Mission Laws' however, and so the church was able to exert influence over not only the community but community leaders as well (Henry 2003).

Secondly, the new social fields of Christianity were materialized through the building of churches. Just as marae and idols were a symbol for traditional worship, the early chapels were "a symbol [of] the Gospel and a physical visual presence of Christianity" as well as a new focal point around which the lives and activities of Rarotongans rotated (Henry 2003: 41). The transformation of power to new religious sites is evidenced by the way old 'heathen' idols were built into the architecture of the church. Gill (1856: 32) and Williams (1837: 117) both describe how some of the traditional idols were taken and destroyed right in front of them while others were set aside, stripped of their sacred bark wrappings and used to decorate the rafters of the newly built chapels. While Gill called this an emblem of the idols' degradation and death, I would suggest that it was a transformation where the power associated with the traditional objects was changed and reproduced within the newer structures of the church. By doing so the new spaces were distinguished from the old spaces of the marae, as well as authorized and validated as the new site of rituals, through the presence of these idols, wrappings, and their associated power. Or as Sissons puts it, the wrapping of the church rafters with the sacred bark cloth charged the building with "lifegiving mana" (2007: 54).

The early churches also represented more than just a physical expression of a new religious order. They "were complex material forms that encompassed those of an earlier social order and that embodied an alternative future society" (Sissons 2007: 57). So not only were the churches an expression of the power of ariki, and the ariki's control of the resources necessary to build such large structures never before built in Rarotonga Williams (1837) describes one that was 250 feet long and 40 feet wide - they also embodied social structures through divisions of space which recognised the importance of ariki, mataiapo, and orometua. Such examples include 
special seating and entrances for the Rarotongan elite ${ }^{5}$. The new social order of Christianity advocated unity and peace between the three districts of Rarotonga, which was further embodied in the churches and the road that was built to connect them. The creation of the ara tapu (sacred path) seaward of the old ara metua (ancient path) which linked marae, and the placement of the churches and Christian settlements on this coastal path, gave the missionaries and the new social order an added power by superseding the sacredness of marae within the traditional Rarotongan cosmology (Campbell 2002b; Sissons 2007).

Finally, the transformation of ritual and practice from the marae and ta'unga (traditional priests) ${ }^{6}$ to the church and orometua completed the transition to Christianity. The early orometua were recognised by the London Missionary Society as being instrumental in the conversion process (Griffin 1827; Tyerman \& Bennet 1832) as they were deeply familiar with the social structures of Polynesia and so worked closely with the high chiefs from the outset $^{7}$. Furthermore they were able to better communicate with their Polynesian peers and explain the Gospel in reference to their previous 'traditional' way of life (Garrett 1985; Henry 2003). So while pre-Christian religious concepts and practices associated with ta'unga were already in the Cook Islands the missionaries transformed these by adding "new ingredients to the Polynesian concept of what a religious specialist might be and do" (Lange 1997: 2). They became teachers of religious and secular knowledge, evangelists (pioneer advocates of a new religion), leaders in communal worship, shepherds of a flock, and community leaders.

5 Maretu tells us that in one of the first churches a special 'throne' was built next to the pulpit for Makea Tinirau, a chief of great importance. However, when the missionary $\mathrm{Mr}$ Bourne arrived he ordered for the throne to be removed (Maretu \& Crocombe 1983; Rere 1980). This suggests that despite the importance of certain chiefs within a Rarotongan cosmology, to the European missionaries the notion that everyone was equal under the house of God was more important.

6 The main duty of ta'unga was to call upon the gods to protect the tribe, or whenever there was need for Divine guidance or help. They also attended to the sick and remedied their illnesses (Rere 1982).

7 Some of Papehia and Tiberio's methods included marrying daughters of ariki and using coercion to gain land (Garrett 1985; Henry 2003). The early London Missionary Society missionaries "soon expressed their reservations about the forceful methods Papehia and Tiberio were said to have used." (Lange 1997: 4). 
So, moving the sites at which 'traditional' practices were carried out to the spaces of the church, as well as native agency and integration of orometua into the traditional social organisation and cosmology ensured the successful conversion to Christianity in the Cook Islands:

"[O]bscured by the superstructure of a missionary-dominated church was the reality of an indigenous religious institution in which the local teachers and pastors played a leading role. From the beginning of the mission to the Cook Islands, Polynesian orometua had been integrated into community life. Permitted at the outset by the chiefs to enter and work, and fed and housed by the chiefs and people, the Maohi teachers bequeathed to their local successors a niche in society that was never seriously questioned by the mission authorities. Orometua were sometimes known as the tama'ua of the chiefs: the phrase signified 'adopted sons', literally 'sons of the lap'. It is not difficult to understand why many aspects of the role of the priest in the old religion were eventually assumed by the new religious leaders, the orometua." (Lange 1997: 12).

As Lange (1997) rightly suggests, while the new structures of the London Missionary Society and orometua were more visible, they were in fact an adaptation and continuation of the local Cook Islands culture rather than a completely new structure.

For the $\mathrm{CICC}^{8}$ the unique amalgamation of Christianity into local practices and social structures can still be seen today; for example, in the performance of traditional hymns and religious pageants, as well as by the important role that orometua play in community life. Despite the influence of the CICC waning with the arrival of other denominations of Christianity such as Catholicism and Evangelical Christians, as the first church of the Cook Islands, it still makes up the dominant share of the religious population; 53\% of the population identified themselves as belonging to the CICC in the 2006 census ${ }^{9}$, although this has slowly declined from a 55\% share in 2001 (Cook

8 The London Missionary Society ceased operations and was replaced by the Cook Islands Christian Church (CICC) in 1965 (Henry 2003).

9 The next largest religious group was the Roman Catholic Church with 2,599 members, making up $17 \%$ of all denominations, followed by the Seventh Day Adventist Church (SDA) with 1,154 members or $8 \%$. All other denominations had less than $6 \%$ of the resident population as members and persons with no religion comprised of $4 \%$ of the 
Islands Statistics Office 2006). In addition, the association of the CICC with the traditional leadership structure of the ariki and mataiapo continue to make the church a significant social and political presence ${ }^{10}$.

\section{Research methods and methodology}

My approach to using space as not only an analytical, but also a methodological framework, was informed by Kim Knott who wrote: "If scrutinising spatial practice is a means to uncovering the spatial system it expresses, it follows that a similar examination of habitual practices associated with religion must do likewise" (Knott 2005a: 40). As an abstract concept, sacred space is not something that can be directly observed, however, it can be experienced through place and the ways in which it orders the body (Knott 2005a, 2005b; Yanow 2006). Therefore, it is only by locating space ${ }^{11}$, its production, and reproduction within the material manifestation of places (e.g. in architecture), observing the way sacred space is embedded in social structures to mediate behaviour and practice, and by experiencing and 'being of' those places, that one can begin to understand and explain the abstract constructions of space.

Consequently, my fieldwork was conducted primarily through participant observation. Methodologically, participant observation is often seen as the core of cultural anthropology (Bernard 2006; DeWalt \& DeWalt 2011; Wolcott 2005). It involves long-term observation of subjects in order to get as close as possible to understanding the 'Other': "The hallmark of participant observation is long-term personal involvement with those being studied, including participation in their lives to the extent that the researcher

resident Cook Islands population. This is based on a resident population of 15,324 people, $67 \%$ of who live on Rarotonga (Cook Islands Statistics Office 2006).

10 For example through the Religious Advisory Council (although it is only one of 6 denominations who is a member of the council, giving advice to the government of the Cook Islands), as well as through presence of the church at official State functions where it is often the only denomination represented.

11 Space is often an 'imagined' abstract concept and the "means whereby the position of things becomes possible" (Merleau-Ponty, 1962: 218). Whereas place, as something concrete, is a location or material site which is an expression of space. It is a site that is given meanings and which shapes the way in which people do things (Creswell 2004). 
comes to understand the culture as an insider" (Davies 2008: 81). As my research was focused on an action-orientated and performative approach to how spaces and places are understood and enacted (Conquergood 1989, 1991), my level of involvement and research of church services can be placed mostly into the 'participation' side rather than the 'observation' side of the participant observation taxonomy (DeWalt \& DeWalt 2011).

My fieldwork was carried out in a period of five and a half weeks on the island of Rarotonga during March-April of $2010^{12}$. I also returned for a short one-week visit to see the national Gospel Day celebrations that are held every year on the $26^{\text {th }}$ of October. I limited the bulk of my participant observation to the CICC in the capital city of Avarua. I attended the main church service at 10am every Sunday ${ }^{13}$, although I also attended church services at other times and at other parishes to observe any differences of space and embodied practice.

While the time frame for my fieldwork was relatively short, I was lucky that it fell within a particularly busy period on the CICC calendar allowing me to experience and observe a variety of church services and practices. My first introduction to the CICC service was a solemn affair with the pulpit and congregation all draped in black for Good Friday, a perfect example of Christian Easter rituals and performances. Other notable services included the rest of the Easter services, a public memorial service (Anzac Day), as well as a special women's service that was held in conjunction with a conference for the CICC 'mama orometua' (female leaders). Of course while these special services may not be representative of the ordinary church services carried out during the majority of the year, the underlying organizational structure between the different church services were always

12 Approval for this research was sought and granted from both the Victoria University Human Ethics Committee (Ref. SACS \# 17365: 12/03/2010) as well as from the Cook Islands Foundation for National Research and Religious Advisory Council. Consent was obtained from the participants interviewed and their names changed to protect their confidentiality.

13 Church services are held on three days of the week. Wednesday and Friday consists of a 5am morning service while Sunday has three services held at 5am, 10am (which is the main weekly service) and at $4 \mathrm{pm}$. 
the same. Therefore even if the weekly theme and ritual practices changed, the use and conception of space hardly ever did.

In recording my field data, I utilised a multi-prong approach (Bernard 2006; DeWalt \& DeWalt 2011; LeCompte \& Schensul 1999). Firstly, I had a notebook of jottings within which I wrote down my observations and impressions when I was directly in the field. Secondly, after services, interviews, and events, I would take the first opportunity to elaborate on my field jottings and write a full description of the events. This was also supplemented by a field diary which primarily painted my personal experience and reflections on events and my methodologies. In addition, while visual anthropology is considered a separate subfield of ethnography with its own methodological concerns, I applied it as a fourth mode of field note taking (Collier Jr. \& Collier 1999; Hendrickson 2008; Pink 2007; Prosser 1998). I took a number of photographs recording both the church services as well as the architecture of all the CICC churches located on Rarotonga. These visual field notes were taken with the intention of using them as a research aid to both analyse similarities and distinctions between the material culture and space of the churches, as well as to help myself recall events and experiences during the later stages of research (Collier Jr. \& Collier 1999). Furthermore, because it would be hard to convey the sense of space that one inhabits when inside the church solely through writing, the photographs have an added benefit of being a visual aid to the reader.

Interestingly, I encountered a peculiar personal dilemma in recording data in the field. I felt that taking notes and photos in a 'sacred' space where people worshipped was an intrusive act even if members of the congregation did not notice. I tried to make my jottings as discreetly as possible and I often only felt truly comfortable taking photos of the services from the doors of the church (and consequently outside of the immediate sacred space of the church) or when the church was empty. This feeling of transgression arose mostly because of my own sensibilities to respect elders and the church's 'sacredness' rather than from any direct disapproval from Rarotongan church-goers for this behaviour (after all, other tourists and visitors freely 
took videos of the traditional hymns without being frowned upon). I viewed this impact on my ability to observe my ethnographic and spatial subject as beneficial in the long run. By highlighting the ways in which taboos and nonsocial cues order behaviour, this dilemma provided useful insights and helped me to rethink the ways in which sacred and religious spaces and places are defined and utilised. It revealed the social norms and values associated with sacred and religious space and also how they might regulate behaviour in particular places, which is what I was ultimately trying to discover in the first place.

Whilst my research was focused on the lived space or experience of churches, I could not fully understand this without also talking to Cook Islanders and discovering their own meanings and interpretations of spaces and events. Therefore I conducted a small number of semi-structured informal interviews with people who attended or had at one time attended the CICC (Bernard 2006). In total I conducted five interviews with eight interview subjects, six of whom attended various parishes of the CICC on the island of Rarotonga, while two interview participants did not attend the CICC at all; however they had been members prior to their departure ${ }^{14}$. Aside from these two participants, all of my interview subjects were active members of the CICC and almost all held some sort of leadership position within the church (e.g. reverend, elder, church leaders etc).

The nature of these interviews varied considerably: they lasted from between forty minutes to an hour and a half and were conducted in places that the interviewee nominated. Some interviews were not planned in advance but done on the immediate availability of the participants when I did not have a tape recorder with $\mathrm{me}^{15}$. Therefore, these interviews were recorded in writing, the interviewees often being kind enough to wait for me to finish writing a quote before continuing. Where quotes used were not directly

14 Both no longer attended because of conflicts with the Church leadership.

15 Although, as O'Reilly has noted, the lack of a tape recorder can be beneficial to the interview process in some instances (O'Reilly 2005:150). In addition I still relied on notes for recorded interviews to provide behaviour cues and analysis, and to negate the noise pollution - especially crowing roosters - in the background. 
written down I have endeavoured to corroborate them with the interviewee (O'Reilly 2005). The interviews were rarely conducted one-on-one. Often family members would sit in on the end of interviews and in two instances interviews I was expecting to be with a single person ended up being group interviews; either because the participants had invited other people they thought would be of interest to my research or because they were spontaneous interviews. Overall, I found this to be valuable as it was easier to establish a rapport and participants appeared to be more reflective about their practices and meaning-making in a collective setting. This may be a result of their comfort talking in a group, the input and questions from other participants (Davies 2008), and because the dialogue that was opened up between multiple participants allowed ideas and questions to be phrased in a way that I, as an outsider, could never have expressed as well.

The interviews were supplemented by informal conversations with informants who elaborated on themes that I was unclear about or who explained what the purpose of something was, for example the order of church services and what certain Cook Islands Maori hymns meant. Structurally, I let the interview participants lead the direction of the conversation and talk about their own experiences with the church, with the purpose to map opinions rather than to produce definitions about the structures of the church (Bernard, 2006). Because my time in the field was limited to just under six weeks and I lacked the opportunity for follow up interviews, an underlying structure of key topics such as hymns, behaviours, and rules within the church organised the proceedings. This was especially so in the last stages of fieldwork when the focus of my participant observation and interviews were refined to the key themes and issues that presented themselves early on (Bernard 2006; LeCompte \& Schensul 1999; Wolcott 2005).

As qualitative researchers, we are taught early on about the influence that our own selves and a variety of factors can have on the data gathered in the field. However, reflexivity on the part of the researcher allows the data and its reliability, validity and generalization to be considered in light of 
these factors (Davies 2008; Fowler 1996; Gobo 2008; Pink 2007). In the case of my fieldwork, I feel it pertinent to mention two issues. Firstly, the relationship with my interview subjects was shaped in various ways. Before I could undertake my fieldwork in Rarotonga I was required to get a research visa, the process of which included obtaining approval from the head of the Cook Islands Religious Advisory Council. He very kindly told me that he would be able to "direct me" to people whom I could interview and who would help my research. At the time I felt that I was being directed towards a church-focused and sanctioned description of the CICC. In hindsight my unease probably arose from a semantic misconception of language as only two of my participants were introduced to me through this connection. In any event, my own attempts to 'gain access' to interview participants still led me to people who played leadership roles within or outside the CICC. Prior to my fieldwork I thought it would be hard to approach church leaders due to their age and status but actually I found that I had no problems at all. I believe this was partly because my younger appearance led to people guiding and helping me (many people exclaimed on the fact that I was doing a Masters degree even though to them I still looked like a high school student!). In fact, I found it harder to engage with youths my own age and consequently did not establish any relationships with them. Whether this was because of a lack of opportunity and time to build rapport or because church elders so often play the biggest role in representing and speaking for the church, I am not sure. As a result, the viewpoints expressed in this thesis are limited to a particular subgroup of the CICC (i.e. leadership) although their opinions should be taken as no less valid even though they are not representative of the entire congregation.

Secondly, as I have mentioned above, I take an approach where I give primacy to 'experience' of space:

"Post-modern ethnography ... does not move toward abstraction, away from life, but back to experience. It aims not to foster the growth of knowledge but to restructure experience; not to understand objective reality, for that is already established by common sense, nor to explain how we understand, for that is 
impossible, but to reassimilate, to reintegrate the self in society and to restructure the conduct of everyday life" (Tyler 1986: 212)

This approach to anthropology focuses on the importance of not only observing behaviour but also the necessity for the researcher to experience bodily practice when undertaking spatial studies (Yanow 2006). Therefore, a part of my analytical and research focus lay in the body, emotions, and senses rather than abstract systems of structure for it is only through understanding the sensory world (i.e. perception and experience) that the cognitive world (i.e. meanings and systems) can be understood (Prosser 1998). In this instance it would be hard to understand why something is classed as 'sacred' or 'religious' without first understanding why people experience it as such before they express it through the physical forms of architecture and behaviour. The charge against such an approach is that it is entirely too subjective, each person will experience, interpret and focus on different aspects of the field. However, while a lot of the initial research was directed out of my own experience of space and the way religious spaces controlled my body, the purpose of the subsequent probing and analysis was to overcome and bracket my own biases so that spatial phenomena could be understood in the terms of those who experience it (Bernard \& Ryan 2010). It is only by first situating themselves within the environment that the researcher can embody and share in the spatial experiences of the people that they are working with (Lee \& Ingold 2006). By recognizing the limitations of the subject matter and meanings we produce, one can strike a balance between the subjectivity of experience and the objective generalizability of systems and phenomena.

The interviews (and informal conversations) were transcribed and subsequently coded using a thematic and discourse analysis approach (Braun \& Clarke 2006). Utilising this process, each interview was first coded descriptively using the respondents' terms (Bernard 2006; Bernard \& Ryan 2010; LeCompte \& Schensul 1999). Following grounded theory (Strauss \& Corbin 1998), the descriptive terms were then grouped together into categories before a final process of deconstructing the data into analytical and 
theoretical codes (Bernard \& Ryan 2010; DeWalt \& DeWalt 2011; Gibbs 2007). The data in each category was constantly being analysed, compared and contrasted to assure consistency and accuracy in the application of the codes (DeWalt \& DeWalt 2011; Gibbs 2007). Alongside the coding and analysis of my data, I undertook a tandem process of constant theoretical analysis of space and place and reviewing the experiences of the church (Bernard \& Ryan 2010; Strauss \& Corbin 1998; Gibbs 2007). This approach to analysis follows Eyring who states: "Because experience is complex, the researcher must fluidly shift his or her focus from the experience itself, to the ground shaping the experience, and then back to the experience. As phenomena are viewed from these many different angles, a richer picture is seen" (Eyring 1998: 141). This interface between data and theory then, as well as reflexivity about the research process, helped to achieve the final deeper understandings of religious space and place around the CICC churches.

\section{Theoretical Perspective: A spatial approach}

From the outset of my fieldwork it was evident that the CICC churches located throughout Rarotonga play a prominent and multi-faceted role in Cook Islands society. In this thesis I will analyse the production and use of the CICC church through a spatial analysis approach. But why should the production and reproduction of space matter in the field of cultural anthropology and religion? Kim Knott states: "[Space] is thoroughly enmeshed in embodiment and everyday practice, knowledge and discourse, and in processes of production and reproduction, and consequently it is enmeshed in religion no less than in other areas of social and cultural life" (Knott 2005b: 166). As religion is expressed through sacred space and conversely religion and religious practices play a part in sacralizing space, I propose that a spatial analysis model can be usefully applied to understanding the production and reproduction of the spaces of the CICC. 
As I have mentioned earlier, in spatial studies the production and reproduction of sacred space has primarily been framed within the divergent paradigms of the politics of space (Arweck \& Keenan 2006; Blain \& Wallis 2007; Hauser-Schäublin 2004) and the poetics of space (Chidester \& Linenthal 1995; Kong 2001; 2010; Manning 2008; Mazumdar \& Mazumdar 1993). For the former the sacralization of space is understood in social constructionist terms, while for the latter the sacralization of space is understood through phenomenological and psychological perspectives (Eller 2007; Kong 1991, 2000). In this thesis I will use these two spatial models to explain the production and reproduction of sacred space in the Cook Islands. In addition I propose a third mode of spatial production - the performance of space. Let us now take a more detailed look at these frameworks.

\section{The politics of sacred space}

The first paradigm of understanding the production and reproduction of sacred space is the politics of space. Chidester and Linenthal (1995) describe the politics of space as being situational. Rooted in the work of Durkheim, they propose that the sacred should be understood as situational because it exists in a "nexus of human practices and social projects" (Chidester \& Linenthal 1995: 6). According to the social constructionist perspective, nothing is inherently sacred, rather, the sacred is "tied up with, and draws meaning from, social and political relationships." (Kong 2001: 213). So, the sacred is situated amongst the profane forces of hierarchical power relations that are variously economic, social, and political (Chidester \& Linenthal 1995; Halgren Kilde 2008). If the notion that profane forces create the sacred is accepted, then we must also assess how this cultural construction is created. For Jonathan Z. Smith (2005), the sacred is expressed through the cultural labour of ritual, history, memory, design, construction, and control of place; in other words it is created through a cultural and political process of sacralization. 
But how does this process of sacralization occur? Van der Leeuw, as outlined by Chidester and Linenthal (1995), provided the basic concepts of 'politics of space' through which sacralization can happen. First, there is the politics of position wherein sacred power positions itself in the world by "selection, orientation, limitation, or conquest" (1995: 8). While Van der Leeuw recognized the transcendence of sacred space and mystification of power (which is akin to the poetics of sacred space discussed in the next chapter), Chidester and Linenthal note that he also recognised that the positioning of the sacred is ultimately a political act and every establishment of sacred place is a conquest of space (Chidester \& Linenthal 1995). Second, sacred spaces are powerful through a politics of property because they are owned and possessed and maintained through claims and counter-claims on its ownership (also called a 'strategy of appropriation' by Chidester and Linenthal). Furthermore, this political aspect of space operates in economic contexts that also serve particular social or political interests and, as I shall expand in Chapter One, these contexts and contests are negotiated through culturally appropriated and constructed 'pasts' (Appadurai 1981). The third politics of space to note is a politics of exclusion, through which the sanctity of a sacred place is certified by maintaining and reinforcing boundaries that keep certain people outside that place (also referred as a 'strategy of exclusion'). Finally, sacralization occurs through a politics of exile that is a modern loss, alienation, or nostalgia for the sacred. In this politics of space, the sacred is positioned in relation to people who find themselves to be out of position (Chidester \& Linenthal 1995; Kong 2001; van der Leeuw 1986). ${ }^{16}$ As I will show in Chapter One, each of these 'politics of space' can be utilised to provide a framework of explanation for the arguments and positioning for the conception, production, control, contestation, and use of

16 Chidester \& Linenthal add two further strategies to those developed by Van der Leeuw to explain the production and reproduction of sacred space: a 'strategy of inversion' which inverts the prevailing spatial and social order; and a 'strategy of hybridization' which mixes, fuses, or transgresses conventional spatial relations and are similar to Michel Foucault's "heterotopias" (Chidester \& Linenthal 1995; Foucault 1986: 24). Although equally valuable concepts, I shall not be addressing these politics of sacred space as they are firstly additions to Van der Leeuw's original four concepts, and secondly they are not directly relevant to the ethnographic data presented here. 
the sacred space that arose during the bulldozing of the Avarua CICC graveyard.

\section{The poetics of sacred space}

The second perspective through which space can be comprehended is the poetics of space. The poetics of space suggests that there is some essential character to religious places, namely 'the sacred'. This has drawn heavily upon the work of Mircea Eliade who postulated that the spatial experience of "religious man" is ordered into the domains of the sacred and profane. Sacred spaces manifest in certain places through "heirophany" - a revelation about the manifestation of power or being in the profane world: "When the sacred manifests itself in any hierophany, there is not only a break in the homogeneity of space; there is also revelation of an absolute reality, opposed to the nonreality of the vast surrounding expanse" (Eliade 1987:21).

In Rudolf Otto's words (whom Eliade drew upon), the experience of the "numinous" (i.e. the sacred or holy) creates a sense of awe and power in the person experiencing the space. This "mysterium tremendum" is experienced as "wholly other"; it is completely outside of the normal experience of the profane world and consequently causes the subject of the experience to be entranced (Otto 1923; O'Dea 1966) ${ }^{17}$. In contrasting the experience of the profane or the feeling of unworthiness (Otto 1923; O'Dea 1966) with the experience of the sacred, a cosmological world and spatial orientation is established by "revealing a fixed point, the central axis for all future orientation" (Eliade 1987: 20). This, in essence, is the causation of the sacred/profane dichotomy (Holloway 2003). Furthermore, because the religious and profane cannot coexist in the same space or at the same time, sacredness requires that religious rituals be performed in separate, special locations and at special times (Durkheim 1915). For Eliade, this sacred time is the time of origins, the creation of a particular cosmology. Moreover,

17 This is rooted in the irrational, whereas for Durkheim, arguably the first scholar to write on the sacred-profane dichotomy, what set something apart as sacred was not its connection to the divine but the degree of prohibition placed upon the sacred object/space; it is something added (Derlon \& Mauzé n.d; Durkheim 1912). 
because sacred time is a time that is circular and repetitious, through rites, rituals and actions the sacred is regularly re-established (Shiner 1972) ${ }^{18}$.

So, sacred spaces can be said to choose to appear; they are linked to "consciousness" (i.e. subjectivity) through the numinous; they are maintained through rituals which highlight the sacredness and timelessness of the site; and additionally, they can create spatial orientations which are either local and bound to particular places of encounter, or universal, in that the sacred is recognised as unfixed outside of the social order (Kong 2001; Lane 1988). As I will show in Chapter Two, the 'poetics of space' are expressed in the landscape. Religious meanings about the sacred are expressed through symbols in place, materialized through architecture, and (re)produced through embodied actions.

\section{The performance of sacred space}

While I will look at both the politics and poetics of sacred space in this thesis, I also argue for a third perspective that allows us to understand space - the performance of space. The idea of performance that I develop here is the sacralization of space through practices (de Certeau 1988; Fowler 1996; Lefebvre 1991; MacDonald 2002). While the use of practice as a means of understanding sacred space/place is not new (Brace et al 2006; Jain 2010; Turnbull 2002), I propose that it be seen as an entirely separate mode of sacralization (Holloway 2003).

As others have noted, practice is what gives shape to space and place (de Certeau 1988; Merrifield 1993). The way in which society and individuals generate and perceive space is structured by practices which may be implicit and informal as well as explicit and formal. Spatial practices that are implicit and informal are embedded in the practices of everyday life (Bourdieu 1970, 1989; Eller 2007). Furthermore, they create a continuity and cohesion in the social formation of space. This cohesion "implies a

18 Parallels can be drawn here between Sahlins' 'mytho-praxis' and Eliade's 'sacred time' (Eliade 1987; Sahlins 1985). 
guaranteed level of competence and a specific level of performance." (Lefebvre 1991: 33, original emphasis). Bourdieu linked the articulation of performance to "habitus" which he described as a system of dispositions that shape an individual's perceptions, appreciations, and actions (Bourdieu 1989; Fowler 1996). These acculturated practices of religiosity and sacredness may take the form of prayer, religious dress, and ways of moving in and between spaces (Knott 2005a). However, it should be noted that practices of the everyday, such as gestures or walking, are difficult to discern as being essentially religious because the same action may be denoted as having another non-religious meaning (Knott 2005a).

In contrast the explicit and formal practices which denote sacred space are actions that acquire sacredness by being enacted in a culturally and religiously meaningful space (Knott 2005a). However, performance and practice simultaneously activate sacred space through the meanings which are placed on the landscape. This dialectic between location and meanings I suggest is crucial to understanding the production of space through performance. As I will show in Chapter Three, meanings of sacred space in the CICC are generated through history, tradition, and a collective performance of (national and individual) Christian identity and which are transmitted through the religious performances of $N u k u$ and Sunday worship.

Additionally, I propose that spatial practices, such as rituals and performance, form a link between the poetics of space and the politics of space. On the one hand the poetics of space - how people perceive the inherent qualities of sacredness within a space - is not accessible to society because of its phenomenological, inward nature. On the other hand, the politics of space is rooted in structures and discourses which are equally inaccessible to society because of its invisible nature. However both of these spatial models are enacted by individuals on and in space/place. The impact of the spatial environment on society (poetics) maps the landscape according to meanings and structures which over time may be "concretized" in the built environment and practices (Knott 2005a: 39). These cultural structures equally impact on the spatial environment (politics) by producing social 
constructions of space that are enacted and embodied through social and spatial practices. Therefore practice can be said to be the mode through which the different processes of space-making converge: "[spatial practice] propounds and presupposes [space], in a dialectical interaction; it produces it slowly and surely as it masters and appropriates it." (Lefebvre 1991: 38).

Finally, there is one further element to the three models noted above which is often overlooked when explaining spatial production: "If space is produced, if there is a productive process, then we are dealing with history" (Lefebvre 1991: 46, original emphasis). History as a representation and context for the production and reproduction of spaces is therefore important in determining how the poetics and politics of space inform each other and how they play a part in the social production of space (Brace et al 2006). In the case of a Cook Islands space, the rapid social transformations that occurred as a result of Christianity are not only important for understanding the social structures, politics, and national identity, they are also important for understanding the conceptions and perceptions of the church as a religious and sacred space and the consequent practices which are carried out in that location.

\section{Chapter Outlines}

The three modes of sacralizing space - politics, poetics, and performance - inform the chapter structure of this thesis. Chapter One begins by looking at the production and reproduction of space through the politics of sacred space, analysing how various discourses of power, embodiment and collective representations, tradition, continuity and transformation are used to sacralize space and to control the physical materialization of that sacredness and experience. My focus is one significant event in present CICC history: in 2003 the bulldozing of headstones of historical and important figures to the early church in an attempt to 'beautify' the church grounds. In Chapter Two, I examine the poetics of sacred space, looking at the symbolic meanings within the church that are expressed as both architectural and social markers, 
and which are used to create and distinguish the spaces of the church as sacred in comparison to its surrounding profane spaces. Finally in Chapter Three, I introduce a new framework for understanding the production and reproduction of space - the performance of sacred space. I compare and contrast practices of spatiality by examining the ethnographic examples of Sunday worship and religious pageants to determine how the location and the meanings of theatrical and ritual performances dialectically produce sacred/profane cosmologies of Christian CICC space.

In this thesis then, I have two objectives. Firstly, I wish to expand the limited spatial analysis literature of religion in Oceania (Campbell 2002a, 2002b; Tomlinson 2002; Toren 1988, 2006; Siikala 1991; Sissons 1989, 2007). Secondly, I wish to follow Kong's call (2001, 2010) and expand the disciplinary and analytical approach to religious spaces. I propose to do this by utilising the notion of performance to explain how society produces and reproduces space (Beeman 1993; Knott 2005a, 2005b; MacDonald 2002; Shiner 1972). Ultimately what these chapters show, and what I will expand on in the concluding Discussion chapter, is that space and place cannot be classed and retained within specific categories, something that has been charged against other writers on space (Knott 2005a; Soja 1980). Rather, what I hope to illustrate through the data and analysis is that the meanings and construction of sacred space and place are not bound to categorical limitations; they are a complex matrix of systems which exist and inform each other continually through practice (Lefèbvre 1991). 


\section{Chapter 1: The Politics of Space: Tradition, Modernity, and the Contest over Sacred Spaces}

\section{Introduction}

In 2003 a curious incident occurred at the Avarua Cook Islands Christian Church (CICC). In this incident gravestones in the Avarua churchyard were bulldozed by the CICC and discourses of power, aesthetics, tradition, and modernity, collided head on dividing the congregation and community. I propose that the levelling off of graves at the Avarua CICC, and the subsequent dialogues which occurred between the church and congregation reveals how such discourses can meet, unite, and be transformed. In this chapter I will illustrate how the four different discourses of spatial politics, namely a politics of property, a politics of positioning, a politics of exclusion, and a politics of exile, were utilised by the CICC supporters and opponents to both control the use and production of sacred space and to transform and reproduce sacred space.

\section{An April fool's day with no laughs: The destruction of the Avarua church graveyard}

In mid to late March of 2003, the Avarua CICC ekalesia (parish) embarked on a 'beautification programme' for their church that was discussed in detail by the ekalesia at their first quarter-year meeting. Usually the ekalesia tended the graves in the churchyard and most families had depended on the church working-bees to look after their ancestors and relatives' graves at no cost to themselves. However, some descendants had not maintained the graves for years. The issue of what to do with them had 
been raised in the past, but no action had previously been taken (Cook Islands News 2003, 2 April). The proposed beautification work was to primarily address the issue of these old unmarked and crumbling graves in the church cemetery ${ }^{19}$. At the main Sunday services notice was given to the relatives of those buried at the church to repair and clean the graves otherwise they would be levelled. As a response, a number of individuals began repainting graves inside the churchyard (Cook Islands News Weekend 2003, 28 June).

Soon after, on the $1^{\text {st }}$ of April 2003, contractors and a bulldozer were brought in to the church grounds, and, on the direction of church elders and leaders knocked down the wall surrounding the church yard and then proceeded to bulldoze graves on the sea-facing side of the church (Figure 1). The next day the work progressed to the inland side of the church. It was stopped however when a member of the Makea family ${ }^{20}$, Eruera Nia protested at the bulldozing. Subsequently a serious conflict broke out between him and members of the Avarua church (Cook Islands News 2003, 2 April). Work was stopped and three days later, on the $4^{\text {th }}$ of April, a march past the church was organised by members of Ngati Makea to voice their opposition to the desecration of the graves. The march began at the post office and ended at the Avarua church, where those who participated (a large number being members of the Makea family) walked around surveying the damage. It was reported that there were no shouts, just amazement and shock at the damage (Cook Islands News 2003, 5 April).

19 Although, only the casing of the graves were ever intended be cleared. The headstones, it was reported, would be left intact and placed on the perimeter of the church. In the church's view a single monument to the deceased would suffice because the headstones didn't have to be erected over the grave that they belonged to. (Cook Islands News 2003, 2 April; 2003, 31 May)

20 There was, and continues to be, no ariki in the Makea family as the title is currently in dispute. 


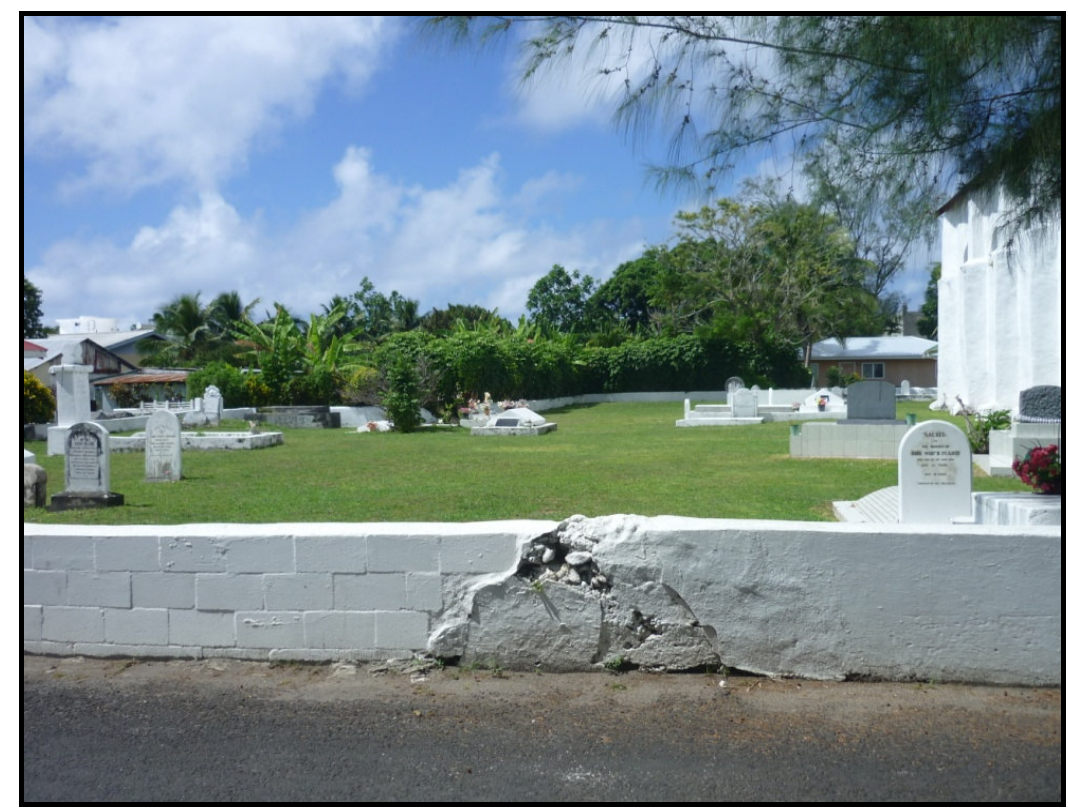

Figure 1: The coastal side of the churchyard where the graves were destroyed. The Church is seen on the right. In the foreground, the damage caused by the bulldozer and subsequent repairs are visible on the left side of the wall.

Throughout the initial period of anger the church continued to attempt to clear graves that had been levelled on the seaward and inland side of the church (although the Reverend promised that no bulldozer would be used after the initial protests; Cook Islands News 2003, 5 April). These attempts continued to be met with protests. The knocked-down headstones were placed at the entrance to the cemetery, flowers were placed in the cleared area where the graves had been disturbed and cardboard was taped to one headstone with a request not to destroy it and to contact the ancestor whose details were written on it (Cook Islands News 2003, 9 April). The area was roped off before further work was attempted again on the $9^{\text {th }}$ of April. This work was again stopped by Eruera Nia and others (Cook Islands News Weekend 2003, 28 June). These first two incidents caused a flurry of opposition to the clearance of graves and there were a number of protests and several letters published in the Cook Islands News newspaper expressing disappointment towards the Avarua CICC. Private charges of wilful damage were even brought against the orometua and tiakono (deacons) of the Avarua church (Cook Islands News 2003, 24 May). 
In the face of the antagonism towards its recent actions, the Avarua CICC decided to delay the work until further discussions between the ekalesia, deacons, and traditional leaders could be had (Cook Islands News 2003b, 7 April; 2003, 9 April). However, these did not progress any further - partly because of the above noted court actions - which also meant that the orometua was not willing to answer the protestors questions (Cook Islands News 2003, 11 April; 2003b, 11 April). Consequently, the church attempted to tidy up the cemetery by finishing the levelling of graves already bulldozed leaving the rest unscathed, although there were attempts to halt this work as well (Cook Islands News Weekend 2003, 28 June). Eventually, the area that had been damaged and cleared was covered with soil and planted with grass and some of the knocked-down headstones were placed against the perimeter wall, while others were left to lie where they fell (Figure 2).
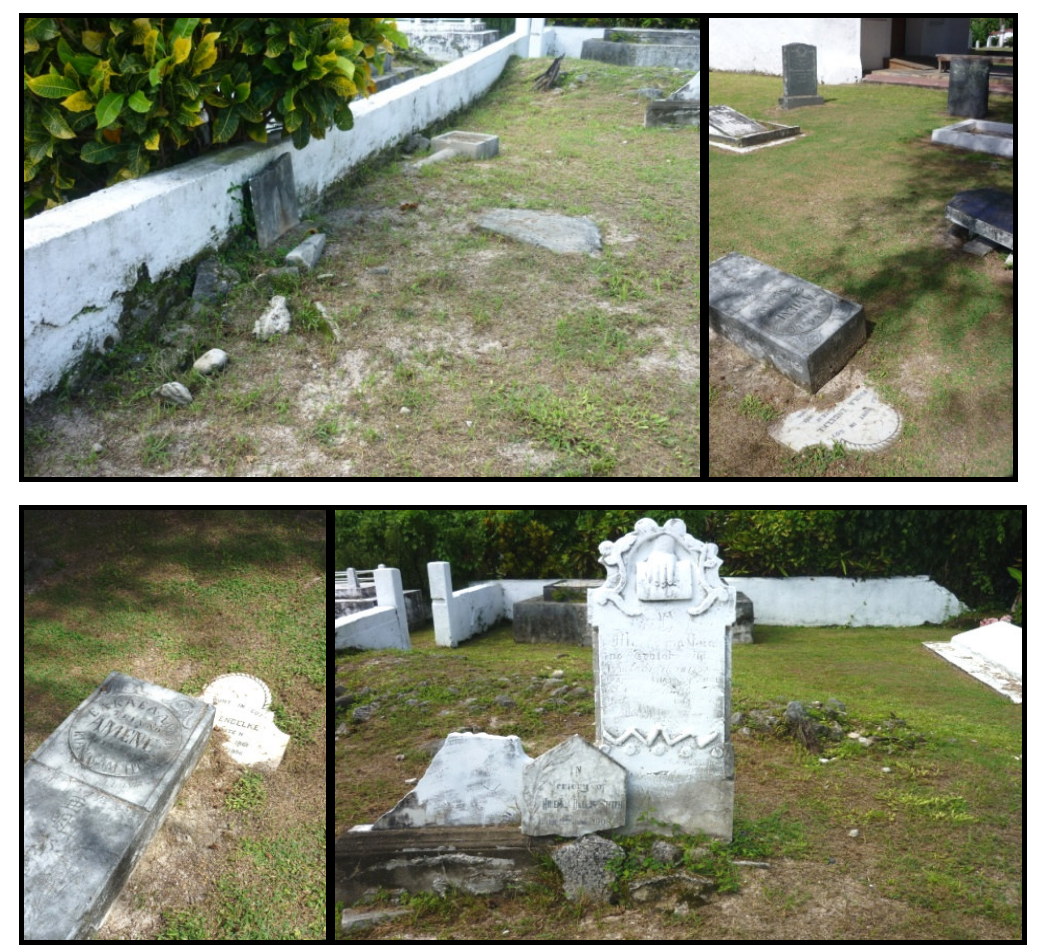

Figure 2: Clockwise from top left: A broken headstone leans against the left perimeter wall. More than five years later, a group of headstones near the front perimeter wall still lie on their sides. Two fallen headstones (detail). A broken headstone is leaned against two other headstones, one of which is also damaged. 
The public response to this incident was enormous. Aside from the heated discussions that occurred in the local newspaper about the role of the church and the importance of the graveyard, the incident sparked a national response as well. On the instigation of a member of the Makea family, the Minister of Cultural Development, Jim Marurai, appointed a new Cultural and Historic Places Board of Trustees who had the power to "identify, investigate and protect any historic place" (Cook Islands News 2003, April 10: 1; 2003, April 19: 1). Even though it was dependent on the church registering the churchyard as a historic site (Cook Islands News 2003, 10 April), such was the public emotion and feeling of importance attached to these events that the Cultural and Historical Places Trust classified the church and cemetery as a historic place under the Cultural and Historic Places Trust Act 1994. Subsequently, the Trust ordered a court injunction to stop any further work being carried out in the cemetery.

Eventually three proceedings took place in court. The first was a criminal action that was issued against the orometua and three senior members of the church claiming that they had wilfully damaged the cemetery (Cook Islands News 2003, 10 April). The second was a claim by Eruera Nia and others to declare the cemetery as an archaeological site (under the Cultural and Historic Places Trust Act 1994). Finally, the third was a counter claim by the Avarua CICC attempting to quash the ruling of the Cultural and Historic Places Trust as illegal (Cook Islands News 2003; 23 June). The Cook Islands High Court dismissed the first two actions and upheld the third action. It also confirmed that the land upon which the Avarua Church and neighbouring Takamoa Theological College stood was gifted to the London Missionary Society by Makea Davida. In addition, the court terminated the interim injunction that forbid any more work on the graveyard, subject to the Avarua ekalesia and the Cultural and Historic Places Trust confirming they would work together towards settlement of the beautification of the cemetery. (Cook Islands News 2003, 20 June; Cook Islands News Weekend 2003, 28 June; Jonassen 2003) 


\section{The politics of space}

So why was this event significant? Why was it so visible and vocal, compared to similar events in the past? For example, Matavera church faced no opposition when they did something similar to the left side of their church grounds. ${ }^{21}$ As I will show in the following sections, the bulldozing of the graves clearly illustrates how cultural constructions of power, embodiment, and discourse were utilised to shape how the location of the church was to be sacralized, controlled, and materialized. These negotiations of space can be better understood by looking at the various texts and enactments of politics of space that I defined in the Introduction.

The main arguments and themes that emerged in this debate were: first, who had the right to the land upon which the church stood? By calling upon a cultural and legal history and 'tradition', each side attempted to validate their arguments and actions for leadership and control of the sacred space. In essence, this was a politics of property and a politics of (social) exclusion. Second, it was argued that the graves were "one of the most sacred and historically important sites" in Rarotonga, because they represented both the church and a Cook Islands national identity (Cook Islands News 2003, 5 April). This can be seen as a politics of exile wherein the sacralization of space produces a collective identity and cultural constructions. The final argument asked what was the nature and 'appropriate' use of that sacred site? This boiled down to how and where people perceived the sacredness of the church to be. Those who opposed the bulldozing claimed the destruction of these particular graves were acts of desecration because the sacred lay in the materiality and continuity with the past. However, the supporters claimed they were merely being good Christians and moving with the times. So for them the sacred lay in practices of Christianity. I propose that this was a deeper argument about

21 Matavera church did not bulldoze the graves instead covering them completely with earth and moving the headstones. This is now a flat lawn which is used by the boys and girls brigades for activities. In the 1970's the Nikao church was moved to its current site and an airport was built over the previous church grounds, surely destroying early graves. As an economically beneficial initiative this might have been more acceptable. 
the use and transformation of sacred space and place and can be conceptualized as a politics of position.

I shall now examine each of these arguments with analysis and reference to the letters sent to the Cook Islands News that capture the heat of the moment reactions to this historic event, as well as the more reflective thoughts that my interviewees raised upon retrospective consideration of the event, to flesh out the analysis in the letters ${ }^{22}$.

\section{Contesting sacred sites: How should places be used and who controls them?}

The most prominent and clear-cut argument that arose out of this incident was framed within a politics of property whereby sacred space and place is powerful because social groups own that place. This ownership is contested and maintained through claims and counter-claims of place (Appadurai 1981; Chidester \& Linenthal 1995; Kong 1993, 2001). By establishing legal ownership over the sacred site of the Avarua CICC church, power and control over the space itself - that is what actions can be carried out within that sacred space and how sacred spaces should be materialized - is also established. The position of the CICC was that the land upon which the church was situated was legally theirs and consequently they could do whatever they wished upon it:

\footnotetext{
"When I mentioned that I am interested in researching the graveyard incident he [a senior Cook Islands Christian Church official] stated that the Makea family wanted to take the land back from the church but when the CICC showed them the deeds, and once they saw that the grounds were given to the church forever, they stopped the action against the church. The Makea's still took the pastor and deacon to court over the destruction of the graves though." (Field notes, 31 March 2010)
}

\footnotetext{
22 Although most of my interviewees were members of the Cook Islands Christian Church, they had cooler reactions to the event as they were not members of the Avarua church parish. However, the two interviewees from the Avarua district exemplified the arguments that each side in the incident had.
} 
Despite the clear legality of property, the bulldozing opponents introduced a cultural element of ownership to the politics of property, namely the 'past' and tradition:

"I simply cannot believe that Makea entrusted the land to the missionaries on the basis of a church only. I'm sure he would have intended for some of this land to be used as a resting place for his people. But if that is the case, who are you to destroy them? On whose divine authority do you claim to be acting? I doubt that our Heavenly Father would have allowed such behaviour.

Just remember, you are "custodians" of the land. It does not belong to you, it was leased to the church and you have no right to touch any of the graves, regardless.

Te Atua te Aroa, Kelly Cook, Rarotonga"

(Cook Islands News 2003, 4 April: 4)

As Appadurai (1981) has noted, the historical pasts of groups play a direct and important role in the expression and resolution of conflicts about the control of resources and structures. He presents an alternate sort of 'past' whose purpose is to debate historical pasts. This 'past' is essentially a process, a "management of meanings", which reformulate, refine, and expand the other pasts of history, ritual, politics, power, and structures (Appadurai 1981: 202). In other words, the claims and counter-claims over place can be defined as a process whereby multiple discourses and narratives are produced and negotiated to establish control of that place and space.

To understand the 'pasts' used to contest the sacred space of the church, it is important to address the relationships surrounding ownership of the Avarua church site. As mentioned in the Introduction, ariki and mataiapo were instrumental in the conversion process to Christianity on Rarotonga and elsewhere by ordering the destruction of marae and idols, and more importantly, embracing missionaries and giving them land upon which the early Christian settlements and eventual churches could be built (Henry 2003). Moreover, the cultural practices and rituals carried out on the sacred site of the marae were transformed, embodied and eventually moved to the new sacred spaces of the church: 
"Interviewee 3: A lot of traditional practices and things done on the marae have now moved to the church ... The structures in the old system have been taken over by the new.

Interviewee 4: ... Which is why I think it was easy to convince the people into Christianity when it was first introduced, because of that shift".

This "shift" is evidenced by the transformation of the role of ta'unga/traditional priest to that of the orometua/pastor (Lange 1997). Significantly, while the investiture of chiefs with traditional titles is still held in the traditional domain of the marae, it now also includes the added sacred element of a church service and the presence of orometua (Sissons 2007). Alongside the emergence of new spiritual and social leadership roles, the traditional leadership roles of ariki and mataiapo were transformed to fit within the new social structure and sacred space of the church. For example, the ariki and mataiapo are always acknowledged by the orometua during church services and pews at the front of the church register their importance spatially $^{23}$. These transformations therefore created not only social and cultural tensions but also a spatial tension in the relationship between traditional leaders and the church. Although Christianity was a democratizing force, the unique position of traditional leadership within the church and the slow spread of Christianity and orometua into daily life created a dual leadership and authority between ariki, mataiapo and orometua who all played a role in the profane spaces of the everyday as well as the sacred space of the church.

These historical, political, and cosmological 'pasts' have manifested themselves in the ariki-church relationship and the way it is described by Cook Islanders today. As one interviewee put it:

\footnotetext{
"Interviewee 4: In the CICC we say that chiefs are our parents, the church is our adopted child. Tamaua means adopted child, so the church is called the tamaua of the chiefs. But the pastor is the one who leads them."
}

23 Except for Titikaveka, the only parish on Rarotonga where the traditional leaders have no separate seats as they consider everyone equal within church. 
I suggest although the legality of ownership was important to the politics of property (indeed this is what the court case addressed), what the cultural politics of property addressed were the underlying socio-spatial tensions that exist in this ariki-church relationship and narrative, both past and present. Naturally, the different leadership in different spaces created tensions about who had power, in what space. Realizing these tensions required the opponents and supporters to re-negotiate how the relationship between the two parties was conceptualized, located, and contrasted against one another in the social structure of the church. Let us now turn to look at the pasts that each side attempted to use in re-negotiating the ariki-church relationship.

Firstly, the bulldozing opponents, in particular the Makea family, attempted to negotiate the politics of property by reasserting a past where the historical importance of the ariki-church relationship was recognized. They argued that the Makea's had provided the land upon which the church stood and that the church was merely a "custodian" of the sacred site (Cook Islands News 2003, 4 April: 4). This suggested that the Makea family should have authority because they were not only cultural owners of the sacred site, but patrons who had allowed the sacred space to be established in the first place. It is for this reason that the lack of "consultation" with the congregation, ariki, and mataiapo (Cook Islands News 2003, 4 April: 4), made opponents upset as their role in the sacred space of the church was no longer valued or respected:

\footnotetext{
"The Rev. Makara says he consulted with the people - what people? Certainly not with the descendants of those people whose graves he demolished.

If he had an ounce of intelligence he would realise some of those people's descendants no longer live here. If he had any respect he would have consulted with the relatives of those people buried there.

.

It appears the Reverend (and I use that term loosely) sought only the okay of his council of deacons. This is another reason for the continued loss of membership of
} 
the CICC church - the lack of respect of the church hierarchy of the feelings of the individuals at the bottom of the rung.

A Reformed CICC"' (Cook Islands News 2003, 5 April: 4)

More accurately, what this lack of consultation highlighted was an inversion of the ariki-church relationship and spatial roles from the norm. The church acted independently and no longer behaved like the obedient child, challenging the nature of the tamaua relationship and also consequently challenging the wider authority of the ariki over the orometua and ekalesia within the sacred space of the church.

Secondly, the past of cultural ownership can also be contextualized within another politics of space, namely a (social) politics of exclusion. The sanctity and sacredness of religious places are maintained and reinforced through physical and immaterial boundaries that keep certain groups removed from the space and in the profane world (Chidester \& Linenthal 1995). By claiming that they had always been traditional owners and as such "hold the right to interfere when conditions are breached" they suggested that the ariki had always had, and would continue to have, control over that sacred space (Cook Islands News 2003, 5 April: 1). Consequently, with the positioning and control over land comes the power to control the use of the land, and more importantly to exclude others if they did not adhere to those uses:

"Interviewee 8: And you know they [the church] are selling the land that we [the Makea's] gave them to get money for themselves. I told them, don't use our land to finance your business, the church is not a business. If they sold the land to help others, like build a school, then I wouldn't complain but I don't like that the church is selling the land to help themselves. And I asked the people at the head office this, is it because you have no feeling for this place? That you are not from this island that you can do this and destroy the graves?

$\ldots$

Interviewer: Do you think that you are passionate about this because you are part of the Makea family, it's your land? 
Interviewee 8: I'm not so sensitive about it because I'm a Makea, or because it's a land issue, but because I was taught to respect the past. All the graves are history, they are people who walked these roads and lived here. But I bet you the people who are in the church, the ekalesia that did it don't even know their own genealogy. But I respect the past because it's what we are today." (Emphasis added).

Although this member of the Makea family claimed they were not upset because it was a land issue, they simultaneously expressed distress at the fact the church was not using the land for its intended purposes to help others. In other words, the church was not fulfilling their perceived role to spread the gospel. Rather the church was viewed as fulfilling their needs and making money off land that was not the church's to sell. Moreover, the exclusion of the ekalesia was illustrated by the opponents' narrative of "respecting" and valuing the past and what the church represents (themes which I shall expand on in the following two sections). Having more understanding and knowledge of the past (i.e. understanding the history and genealogy of the graves) positions the opponents as owners of that knowledge and therefore appropriate gatekeepers of the space of the CICC church and churchyard. This knowledge and respect gives them authority to continue protecting the space.

Within the politics of property framework, the ekalesia similarly introduced the politics of exclusion to assert their claims over the land. While the role of chiefs and the opponents' version of the past was not denied by the supporters, for them this claim had less standing because there is currently no Makea family title and so they had no authority to "dictate" the actions of the congregation (Cook Islands News 2003, 4 April: 4). Additionally, a traditional title did not give immediate authority to ariki and mataiapo to dictate the actions of the ekalesia within the sacred space nor did a title "protect the holder from legitimate criticism", rather they had to "gain respect and trust by demonstrating, by example, a lifestyle above criticism.” (Cook Islands News 2003, 4 April: 4). 
In Rarotonga, over the last few decades, ariki and mataiapo have slowly ceased to actively participate in the CICC:

Interviewee 3: "They [the ariki] are the ones who first accept Christianity and they don't go to church.

Interviewee 5: In one way it's sad. They introduced Christianity and they don't go ... 30 years ago there was always some kind of closer relationship that the ariki would work with the pastors and deacons. Sometimes they even held positions in the church, but not anymore.

Interviewee 4: But we still acknowledge them even if they do not attend church all the time."

Interviewee 2: "Because before, elders in the church are the most influential people in the villages, and they hold power in the village as well. But now that they starting to uh (...) I think it's already gone. There is no more mana, no more power.

Interviewer: And why do you think that is?

Interviewee 2: People are starting to move away from God, from their faith. That's my own belief. Because I can see now, I can experience how that the elders of the church are not as strong as our forefathers. Now they, because of modern time, and changes in time and things changed as well, so their faith in what they used to believe is now (...) they are double minded now. Whether I hold on or open the door for other things to happen, for new things to come."

Of course, traditional leaders who still attend church continue to command great respect, but because to date the Makea title continues to be in dispute, and because many of those opponents to the bulldozing did not attend church or lead by example, it meant that in the eyes of the congregation the credibility of the ariki and mataiapo was diminished in protecting the sacred space of the church. It could be said then, that there was a similar dissolution of the tamaua relationship for the ekalesia, as for the ariki and mataiapo. Rather than being the rebellious child, however, to the ekalesia their actions were justified because the traditional leaders had failed in their role to continue acting as Christian leaders and examples to the community. Therefore the ekalesia had more respect for the CICC leadership, and perceived the authority to change spaces to reside with them rather than with the traditional leaders. 
The ekalesia rationale for exclusion also extended to those that were not traditional leaders. The supporters argued that they had a right to beautify the churchyard because they regularly attended church services:

\footnotetext{
"An emotional Margaret Karika challenged Nia to apologise to Reverend Makara for his actions. "We're the ones who come to church and listened to the Reverend saying to beautify our graves since early March. You never came to church, especially all of you who protested that day."' (Cook Islands News 2003, 11

April: 5. Emphasis added)
}

As a result, because the ekalesia are the ones who utilize the church grounds every week and whose experience of the space is most affected by changing the graveyard, they claimed to have a right to alter the sacred space.

Thus, for the ekalesia, by placing emphasis on their own practice and experience, power over the sacred slowly came to reside with the CICC rather than in any traditional conceptions of ownership and authority. Although not a politics of exclusion where physical boundaries separated the sacred from the profane, this re-conceptualization by ekalesia of sacred space was a politics of exclusion whereby social boundaries between the ekalesia, ariki, and other opponents was created. The supporters' conceptions of Christian practice and use of the church grounds created a sacred space that denied bulldozing opponents any voice and authority within that place. In employing a politics of exclusion to counter the past presented by bulldozing opponents, the ekalesia were removing them from the politics of property process and the ability to renegotiate the past.

In summary, the discourses of politics of property and politics of exclusion were used to renegotiate the relationship between supporters and opponents, past and present. The church used narratives of historical legal evidence and practices grounded in use to show the grounds were theirs while the opponents used their role as traditional custodians of the land and keepers of knowledge to argue for their continued role in the protection of the site. As was eventually proved in court, the land which the church rests upon was given to the London Missionary Society by Makea Davida "to build a 
church and use for whatever means to spread the gospel" which in this instance meant being able to utilize the church grounds for the ekalesia and Christian practices (Cook Islands News 2003, 2 April: 1). In the end, legality prevailed over the cultural politics of space and processes of the 'past' to establish control over the sacred space of the church.

\section{Constructing sacred sites: History and tradition is sacredness}

Although the ownership of space was settled through a politics of property, the crisis that emerged from the bulldozing evoked two further discourses around the social and political production and reproduction of sacred space. In this section I shall address the process of sacralization that made the space of the church and its graveyard sacred for Cook Islanders by highlighting the meanings of sacredness that were associated with both the material and intangible aspects of the graveyard.

Graves (and bodies) are powerful objects in that they not only represent individuals and their memory, but they can also be symbols of "ambiguity, multivocality, or polysemy. ... Their complexity makes it fairly easy to discern different sets of emphasis, extract different stories, and thus rewrite history" (Verdery 2004: 306). But what different meanings were associated with the graves in this occurrence? As Antonius Robben has noted, death and mourning are not limited to individuals but can also be "a general expression of loss for a social collectivity under threat", including the threatened desecration of religious symbols (2004: 8). As I will shortly illustrate, the destruction of the graves can likewise be seen as both a disturbance of the engagement with deceased individuals, as well as a greater disturbance of what those graves represented, namely a collective Christian past and tradition. This sense of importance and looking back at past ancestors can be framed within the politics of exile whereby there is a modern nostalgia for the sacred. This view of the sacred is constructed in relation to people who find themselves to be out of position (Chidester \& Linenthal 1995). 
The first and foremost understanding of graves, and the bodies which lay there, was as embodiments of individuals. Although no longer living, the headstones and graves are material representations of the deceased containing fragments of their personhood. As fragments of personhood, gravestones remain powerful agents as they continue to generate emotional responses and mediate social relationships (Gell 1998, 1999; Hallam \& Hockey 2001) ${ }^{24}$. For example, the living walk through the graveyard each Sunday, they clean and tidy the space of the graves and may partake in rituals which commemorate those individuals that reside in the space (Hallam \& Hockey 2001). Therefore, although deceased, the bodies within the graveyard are not socially dead as there are ongoing interactions between the deceased and the living. This ascription of agency was visible in the language used by opponents:

“... He [Orometua Makara] has disturbed the sacred grounds of our ancestors who embraced Christianity. Have they woken up? Most definitely I think. So what if the graves were unattended. These graves had/have beauty and character. They told many stories. What do the tiakono do? We'd hate to think! ..."

Teariki Apai, Ratio Matariki, Wellington NZ (Cook Islands News 2003, 7 April:

4). (Emphasis added)

So, not only was the destruction of graves a destruction of material symbols, it was also an assault of deceased individuals and all the agency, personality, history, and memory that they contained. Furthermore opponents asked "how will you know who is buried where? What if the families that have been living overseas all these years return home to look for them?" (Cook Islands News 2003, 4 April: 4). Therefore in the opponents' view, to destroy the graves disempowered the living from

24 It is important to note that as "agents", the objects do not have an agency of their own per se; rather, intentional beings (i.e. an individual) give artefacts, including graves, an agency by engaging with or having a causal reaction to the object. Although essentially an attributed agency, objects can over time take on a 'life' of their own and act independently of those persons who gave them agency in the first place (Gell 1998, 1999; Jones 1993). 
interacting with the dead, as the dead were no longer visible agents within the space of the churchyard.

It should be noted that not all agency was to be removed from the graveyard. Those which were maintained and painted after the first call by the orometua to tidy the graves in March remained intact because the ekalesia continued to enact a personal engagement with those bodies, their agency, and their memories (Cook Islands News Weekend 2003, 28 June). It was only those graves that had become unmarked and were often crumbling in on themselves, which the ekalesia proposed to bulldoze. They remain to this day coral limestone cases, shells for people who are no longer remembered by name (Figure 3). For the supporters, it was acceptable that these graves be destroyed because they had no personal engagement with them. These graves were not part of their ideas of what the sacred space was, nor were the graves part of their everyday use and practice within that space.

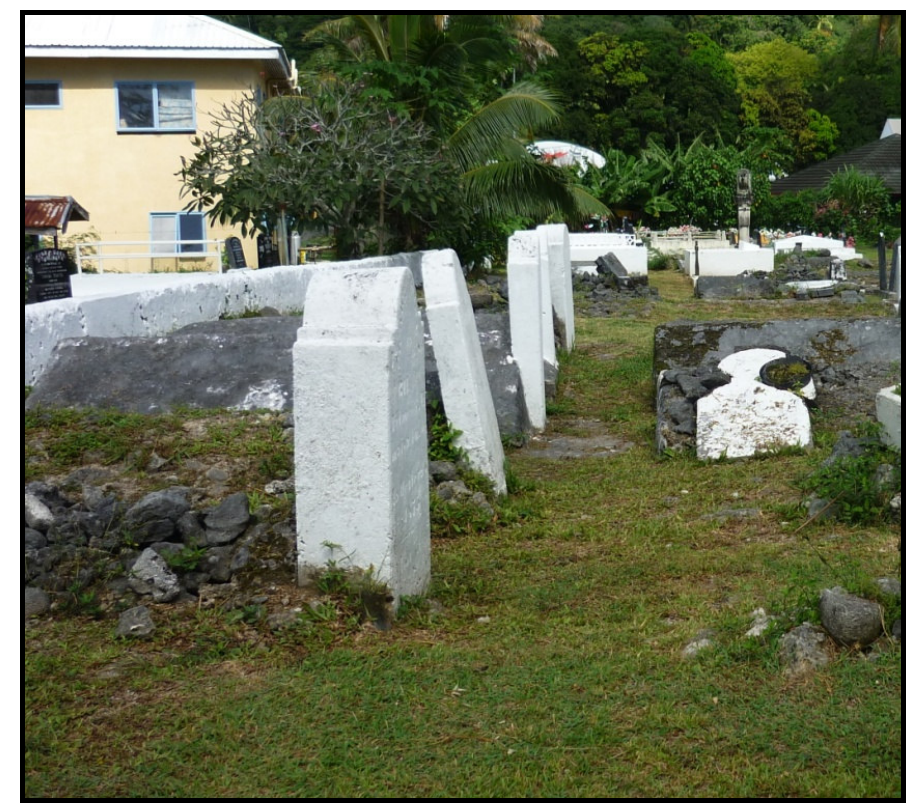

Figure 3: A row of white painted headstones by the rear wall of the Avarua churchyard. There are no clear visible names on them. The front most grave on the left is an example of where the casing has collapsed. Graves with such collapsed casings are what the Avarua ekalesia wanted to remove. 
However, for the opponents, excluded from the everyday use of the graveyard this space of the church instead took on very different meanings of awe and cosmic concerns (Verdery 2004). Sacred space orders the cosmic concerns of the world and dangers associated with the dead (Yeoh 1991). I suggest though, that an important reason the event caused friction was that the living were now the ones harming the dead and all the sacredness and continuity with the past that they represented. By not engaging regularly with the space, the opponents constructed a modern nostalgia and romantic view of that space as embodying the CICC itself, as well as a treasured past and Christian tradition. This is the second form of embodiment that the graves represented ties to the politics of exile. To understand this second form of embodiment, namely the representation of a collective past and organisational identity, it is necessary to understand the meaning of graves in the churchyard in relation to other gravesites.

Land ownership in Rarotonga is based on native and customary title. Because of the lack of public cemeteries, it is therefore a common sight to see graves and burial plots on family land, sometimes even right next to residential houses. The graves in the churchyard are distinct, however, reflecting the devout Christianity and "status within the community" accorded to those who are buried in that space (Cook Islands News 2003, 4 April: 4). Historically, missionaries and their wives and children, orometua, and deacons were the only ones who were buried within the church yard (Cook Islands News 2003, 5 April). This is a practice that continues today:

\footnotetext{
Interviewee 7: "Maybe I think they do it [the graves in the church] as a way of honouring those people for services in church."

Interviewee 6: "If you've been serving in church, it is one way of honouring them, to give them a place to rest."
}

The reason for this distinction in who is buried around the church is twofold: it is a practical solution when the deceased members of the church have come from outside of Rarotonga and consequently have no customary land of their own in which to be buried, and as mentioned in the above 
interview, it is a sign of honour and respect for the service that ekalesia, deacons, and orometua have given to the CICC. It is this latter reason in particular which was appropriated to construct a representation of material objects beyond fragments of individual personhood to collective symbols and identities.

For protesters, even if the name of the deceased is no longer known, the graves in the church yard are all significant to the history of the CICC. The graves took on additional meanings and agency as mediators for a Cook Islands Christian identity and nationhood. Because it is acknowledged that typically only people who are significant to the establishment and maintenance of the CICC have been buried within the church graveyard (such as early missionaries), the graves transcend being just embodiments of the deceased and come to represent the early church as a whole:

Interviewee 2: "There was an incident here when they started to straighten up the graves; I don't know what's behind it. But I was part of it when the thing happened, but we did it as what we were instructed to do. ... But I realised that it was wrong. As part of your heritage why demolish all these [graves]? They say it's only a graveyard, but there is something inside that signifies the church, the history when we look at the church and those graveyards, not all of them, some of them are important people that helped out with the development and growth of the church. So I'm glad that it's still there because if you travel around the islands, most of these big churches have graveyards beside them." (Emphasis added)

\footnotetext{
"The Avarua CICC cemetery is not only significant for the families of the people buried there but it is both culturally and historically significant for all Cook Islanders because it is the nearest thing we have to a monument for our founding fathers. The founding fathers of both Maori and Europeans who made a significant contribution to the formation of our nation - early church people, Maori and European, as well as their wives and children, are all buried there.

... In countries overseas the monuments and graves of their founding fathers are carefully preserved - not here, they are bulldozed to make way for a lawn!"
}

A Reformed CICC (Cook Islands News 2003, 5 April: 4)

The church, and the graves in particular, come to represent a Christian heritage and identity and were akin to national monuments in other 
countries. The power of the graves can be attributed to the historical and cultural meanings and the personal memories that bodies can evoke. They are objects which "have the advantage of concreteness that nonetheless transcends time, making past immediately present." (Verdery 2004: 305).

Once more, excluded from the use of space, the protesters also constructed and sacralized the space of the church according to the materiality of the space. As the above interview points out, the normalcy of graves around most $\mathrm{CICC}$ churches reinforces the perception that this is what the sacred space and site of the church should look like. Therefore, the destruction of these material symbols of the past and history of the church is viewed as a destruction of not only representations of individuals but also a destruction of a wider sacred representation of the church.

To summarise, opponents in this incident claimed that a loss of memory as to who lies in those graves is not enough to enable their desecration. They argued that as resting places of early church members and converts to the CICC the graves should be preserved for their historical importance. In short, for them the graves stood as markers of a united Cook Islands history and in particular represented the close association that many Cook Islanders see between the first church and the creation of an identity of faith and nation. The church and its grounds are an important part of Cook Islands tradition(alism).

\section{Changing sacred sites: When does beautification become desecration?}

The final discourse in the process of control and sacralization of the Avarua graveyard was about the change and transformation of space. On the one hand, the church and ekalesia claimed that by changing the appearance and order of the sacred space of the churchyard they were merely beautifying it. On the other hand, the opponents claimed that to destroy these gravestones was a desecration of history and the sacred space and 
place that was symbolised in the church. On the surface, it is easy to reduce these arguments to aesthetic judgments ${ }^{25}$, but framed within the politics of position they are concerned with the contest and discourses that can arise when sacred spaces are changed. Understanding how space is actively and socially constructed, allows a clearer analysis of the continuity and transformations of sacred space.

The politics of position suggests that despite a phenomenological aspect of the sacred, the establishment of such places is through a selection, orientation, limitation, or conquest of space (Chidester \& Linenthal 1995). In other words, despite whatever divine awe or revelation that may occur at a place, this is not enough to make that place sacred. Rather, sacred spaces are selected and constructed consciously. In the case of the CICC, it is clear that their locations were informed by political, cultural, and cosmological reasons.

Firstly, the church is sited on land that was donated by ariki (Henry 2003; Lange 1997). The active role of ariki in the conversion to Christianity was certainly motivated by political interests and by providing the land for Christian settlements; they not only consolidated their surveillance over the new social structure and power within Cook Islands Christianity, they also validated the church and its activities to the Rarotongan population at the time. This is still evident today as all three ariki residences on Rarotonga are situated adjacent to a CICC church. Secondly, the transformation from the sacred space of the marae to the church was enabled not only by a shift in cultural practices, but also the deliberate placement of churches within Cook Islands cosmology. As I mentioned in my Introduction, the

25 The discourses about aesthetics can also be analyzed from a phenomenological perspective. Indeed, the poetics of space, which I shall address Chapter Two, does play a role in understanding Cook Islanders' reactions to the destruction of the headstones. Aesthetic judgements are often purely subjective; for one interviewee, Nikao church without any graves was considered beautiful whereas another liked looking at the graves at Avarua because they thought they were beautiful in themselves. Certainly, if one looks at the landscape of the different Cook Island Christian Churches on Rarotonga, contrasting those churches which still have gravestones on their grounds (Arorangi, Avarua, Titikaveka) with the 'uncluttered' churches that have no gravestones (Nikao and Ngatangiia), then it is easy to see where the different judgements, aesthetic appeal, and utility of having no gravestones around the church yard come from. 
incorporation of traditional idols into the structures of the church essentially transferred the sacredness from marae to the church (Gill 1856; Henry 2003; Sissons 2007). Finally, the proximity of the church to already established sacred spaces of coastal marae, their location close to the coast and ara tapu (sacred path), situated the church along a cosmological plane which marked them as being highly sacred (tapu) buildings (Campbell 2002b; Sissons 2007). The location of CICC churches therefore can be seen as a deliberate challenge by Christianity to traditional sacred spaces ${ }^{26}$.

The creation of the sacred space of the church then, was a conquest over an already established sacred space. It was not a construction of a blank space that had no meanings associated with it, nor was it entirely replacing one social construction of the sacred with another. Rather as mentioned previously, this was a "shift" in practices and conceptions of Cook Islands cosmology (Lange 1997). They were conscious transformations of sacred space and its associated meanings and practices. In this section I suggest that the bulldozing incident was a similarly nuanced understanding of the politics of position as the definitions and use of sacred space are continuously involved in processes of reproduction and transformation.

So how were the discourses of transformation (and conversely continuity) expressed during this incident? Firstly, as a manifestation of the divine, churches and their surrounding cemeteries have historically constituted the sacred heart of the city (Foucault 1986; Yeoh 1991). The materialization of cosmologies and the sacred in particular places therefore made those places sites that mediated and organised both daily practices and rituals. They were the 'spatial hub' around which Christian time and practice rotated. So too in Rarotonga, the churches are spatial markers of Christianity which order practices and routines. What became the focus of

26 It should be noted that this challenge was not met without resistance. There were ta'unga and mataiapo who had equally resisted the transformation of the marae spaces as opponents opposed the transformation of the graveyard. Rere notes that these historical protesters made attempts to attack the symbols of transformation by burning down churches and missionary settlement houses (Rere, 1980). 
attention here was that the transformation of the established sacred space did not fit the bulldozing opponent's conception of what the development of that spatial hub and spatial practices should be. Opponents resisted transformation, because, as mentioned in the previous section, to alter the church and churchyard was to alter the sacred representations that existed within that space. Simple aesthetic changes like re-painting the church or graves do not cause any conflict because the materiality of the church and its associated sacredness remains the same. However, significant material alterations change the inherent character of the space, forcing people to engage with the place differently. Thus, if material aspects of the church and cemetery no longer exist then it cannot be a place that represents the sacred space of Christianity, nor can it mediate religious practices in the same way.

Socially excluded, the opponents were not engaged with the space of the church, nor did they perform practices there on a regular basis. They were not part of the discourse of continuity that the ekalesia had with the space. Thus the opponent's perception of the space was one of history, the continuity of which was maintained through timelessness and traditionalism of practices:

Interviewee 8: "When you look behind you there's always going to be something behind you, it's not just air. Those people don't understand there is a history there and they wanted to pull down the graves just because they were old and ugly. It's funny, because my father is buried in a yard just up the road, and I always thought that the people in the churchyard are lucky because they are there forever. They're safe in there, it's permanent." (Emphasis added)

As evident from the above statement, the sacredness of the space lay in not only the embodiment of history as previously discussed, but also in the permanence and timelessness which were attributed to the material markers of this history and national identity. It was imperative to opponents that the space remain physically the same because any changes to the space endangered the sacredness that is perceived there as well as the continuity that the space has with the establishment of a Christian nation. It should be 
noted, though, that the continuity of the past and sacredness of this space is a cultural creation as the space of the church and the graveyard did not always exist. The sacralization of the Avarua church was only established after the land had been gifted and Christianity had been established as part of the Cook Islands social and cosmological system. The people outside of the church who criticise the destruction of the graves in fact romanticise the qualities of timelessness and embodiment of history. Therefore to bulldoze and change the inherent sacredness, traditionality, and continuity of the graveyard was to modernise the space.

Lastly, in addition to the material transformation of sacred space, there was also a wider opposition to the process of transformation. As mentioned earlier, there was no proper consultation with opponents about changing the space (Cook Islands News 20034 April; 2003, 5 April). Because traditional leaders have historically led these conscious transformations about the idea and use of space and place, like the shift from marae to church for example, they have had agency in the transformation of sacred space. But due to the politics of property and the politics of exclusion, the opponents were disconnected from their ordinary role as leaders in the tamaua relationship and agents in the transformation of space.

For supporters, it is the people who attend the church and who use the space and place daily, that symbolise what the church is in this moment now. For them the concept of sacred space is not static but one which is utilised for a purpose; the space of the church is in fact for generating practices of Christianity and worship. In one case, the lack of graves around Matavera church means an ability to use the space in order to teach Christianity to individuals through practices and youth group activities (Figure 4). Because such social and spatial practices are located in the present not the past, the supporters saw no wrong in changing the space of the church yard and its associated meanings and usages. Therefore, because the process of sacralization lay in practice and not symbolism, material 
objects, or the past, the ekalesia saw their actions in changing the space as continuous with tradition and history rather than radically transformative $\mathrm{e}^{27}$.

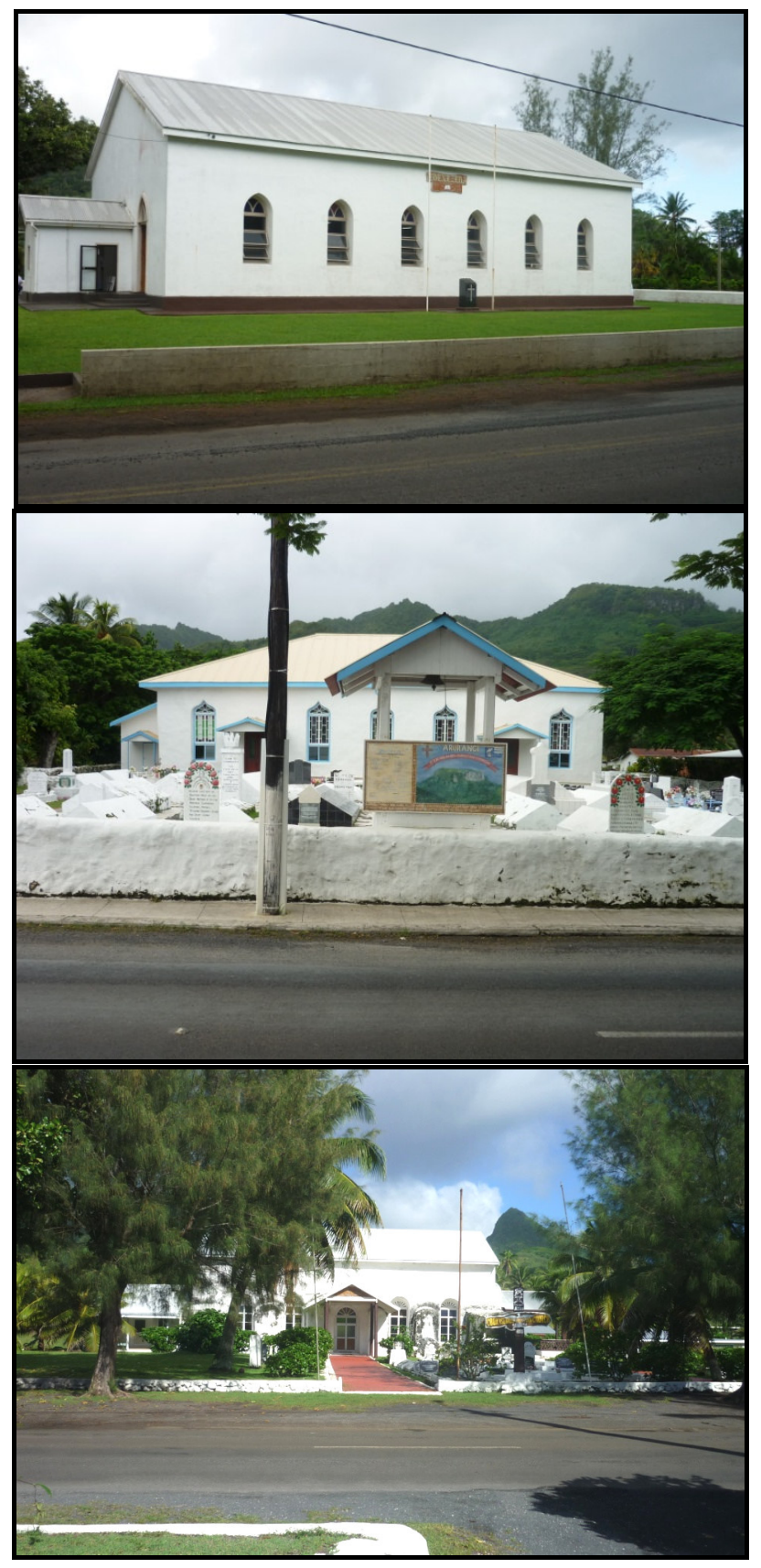

Figure 4: The Ngatangiia church exterior (top) compared to the Arorangi church exterior (middle) contrasts the space available due to the lack of graves with the presence of graves in the church yard; Matavera church (bottom) is somewhat of an exception. There are graves on the right hand side but the left is an elevated lawn where the graves were covered with soil.

27 This is in a sense a counter-argument to the idea that the space should be controlled by the ariki because the church was not utilising the land to spread the gospel. 
Furthermore, for the ekalesia the beautification of the grounds was a means through which the church was "working with the times" (Cook Islands News 2003, 5 April: 4). Although the physical aspects of the space were perceived as new and transformative, the church's role as a mediator of change was also a continuation of the historical role that it had in materializing new social fields. By this I mean that when Christianity was first introduced to Rarotonga, the church was a force for change, altering sacred spaces. The church was a materialization of modernity and the marae was traditional. As other denominations were introduced to Rarotonga, the CICC slowly became the 'mother' church and traditionalized in comparison to 'modern' Pentecostal churches. In actively transforming the space to become modern, the church was reasserting its role in controlling the discourses of tradition and modernity. As mentioned earlier, this process of sacralization and the ability for the church to represent continuity and change to the ekalesia lay in the ability of the graves to represent multiple meanings. Graves are "... metaphors of memory, which connect the intangible with the material, either convey notions of fixity and stability or they highlight process and transformation. At either end of this spectrum, however, metaphors of memory always allude at some level to continuity." (Hallam \& Hockey 2001: 27). The past and the present therefore collapse in one site and object (Hallam \& Hockey 2001; Verdery 2004). So, the graves were part of the dialectic where the traditional became modern and the modern became traditional and thus sacred as well.

To review, this incident was about the continuity and transformation of sacred space. Using the pasts, exile and exclusion, the ideas behind the use of space were positioned as either timeless and continuous or as transformative and changing. The sacralization of space was through not only ideas but through practice as well. For those who opposed the bulldozing, umbrage was taken at the attempt to akamanea (beautify) the churchyard because it challenged their concepts of what the sacred space was. They attempted to reassert traditional models of leadership from the past and viewed the space as being timeless, and thus "traditional". 
Conversely, for the supporters, the space was anything but timeless. For them the sacred was manifested in their own practices and use of space, rather than in anything material. By changing the space and "working with the times", it was simultaneously a symbol of modernity, and a means of addressing the user's needs and sensibilities within the space (Cook Islands News 2003, 5 April: 4).

\section{Conclusion}

While the gravestone incident is not emblematic of Cook Islands society as a whole, it may be taken as an important example of how the politics of space can shape the manner in which places are conceived and constructed. As shown in this chapter, the production and reproduction of the CICC graveyard at Avarua was framed within narratives of power, history, and transformation.

The control of the sacred space and how it is used was achieved through a politics of position. This is a process where past meaning and narratives are actively utilised by groups to consolidate or establish their

power and control over space (Appadurai 1981). In this instance the peculiar cultural history of Rarotonga and the tamaua power relationship was brought to the fore as evidence or counter-evidence during the negotiation for the control of sacred space. Multiple discourses and narratives or "pasts" informed this negotiation. They included the politics of exclusion, whereby each side socially excluded the other from using and controlling the space, and the politics of exile where those who had been excluded from the space constructed a romantic and nostalgic view of that space which was based in agency and embodiment. These politics of space were in a sense used to sacralize the space of the graveyard as part of the final politics of space, the politics of position. I proposed in this chapter that this discourse is about the conscious transformation and use of space. During this event both sides argued that their conception and use of space remained 'traditional' and thus continuous with the narratives of the past 
that sacralized the space of the church. For opponents the sacredness of the space lay in the material expression and experience of that space, therefore they felt the physical site should remain the same. However, for the ekalesia, although the space changes physically, their actions do not. Therefore, for them, the sacralization of space lay in the continuity of practices.

In the end, what is apparent is that the process of sacralization through politics of space involves multiple discourses, politics and power, and social and cultural meaning-making. What is more important to note though is that these discourses were all enacted through performance and practices (i.e. bodies facilitate the understanding of space as agents that can ascribe and negotiate meanings and practices of a space). Furthermore, the re-negotiation of meanings about the Church site was a performance, a "social drama", in itself (Turner 1974). The performative aspect of political space therefore begins to make itself apparent. This shall be expanded on in the following chapters, especially Chapter Three and the Discussion. 


\section{Chapter 2: The Poetics of Space: Social and Architectural Symbols of Sacred Space}

\section{Introduction}

In Chapter One I looked at the production and reproduction of sacred space in the Cook Islands within a politics of space framework. In that chapter I briefly addressed the poetics of space and what some of the subjective characteristics of sacred space are for Cook Islanders through a cultural and political lens; for example, the purpose of negotiating narratives and ownership of space is to control the subjective experiences and practice of the sacred. Additionally, how one experiences and practices the sacred determines the authenticity given to narratives of authority, control, tradition and continuity. In this chapter I wish to expand on the subjective spatial experience by looking at the production and reproduction of sacred space through a personal and cultural lens. I will firstly look at how space can be sacralized though architectural markers. I show that architecture materializes the separation between the sacred and profane and it also helps enhance an individual's experience of religion and sacred. Following on from this I shall look at the way the social experience of the sacred interacts with individual's internal experience of sacred. The internalization of social and personal experiences of the sacred (re)produces spatial and behavioural orientations.

\section{The poetics of space}

To quickly summarise the definition of poetic space described in the Introduction, subjective and internal production of space consists of the following elements. Firstly, the sacred establishes in certain places as revelations (heirophany). Secondly, these revelations are linked to subjectivity in that spaces are only sacred when a person recognizes and 
experiences it as such. This is through an enchantment and awe in those experiencing the space (the numinous). Thirdly, sacred space is maintained through rituals that emphasize the difference of the sacred from ordinary, everyday spaces. Finally, sacred spaces create spatial orientations that are both local and universal (Chin-Hong 2007; Eliade 1987, Kong 2001; Rennie 2006). Together, these aspects can be described as a substantive construction of the sacred that I shall examine in the context of the Cook Islands Christian Church (CICC).

In understanding and analyzing the ethnographic data, it is necessary to note that the poetics of space implies a subjective appreciation of sacred space $^{28}$. While I incorporate my own sensibilities of space into the analysis of the ethnographic data and space I have also included within this analysis the manner in which personal understandings of space are expressed and practiced within the cultural system of the Cook Islands. In this instance, how have the qualities and perceptions of sacred space been expressed verbally, socially, and physically by Cook Islanders?

\section{Architectural markers of sacred space: The materialization and ritualization of the sacred}

The poetics of space first establishes sacredness through heirophany. These are subjectively experienced as powerful and enchanting (numinous) making a person aware of the distinction between sacred and profane space (Eliade 1987). Before proceeding with how these two aspects of poetic space are expressed in the CICC church, it is necessary to address a fundamental tension in Eliade's understanding of sacred space. A narrow reading of hierophany implies that when a person experiences awe and enchantment in a place, they are reacting to a direct manifestation of the sacred/divine within that place (Brown 2004). In other words, individuals perceive that there is an actual fragment, or index, of the divine within the landscape or building

28 Evans (2003), makes a useful distinction between individual subjective experience of the supernatural called the "spiritual sacred" in contrast to "religious sacred" which is created by a group. 
which has its own agency and power to mediate social relationships (Gell 1988, 1998, 1999; Jones 1993, 2000; Sack 1980) ${ }^{29}$.

Yet, the space of the church cannot be understood as a personification of God as a pure poetics of space would have it. In fact, the concepts of sacred space must be understood in the context of the historical roots of the CICC. The missionaries who introduced Christianity to the Cook Islands had a Protestant theology; thus missionary-built churches were constructed with Protestant perceptions of space (Brown 2004; Halgen Kilde 2008). For Protestants:

"'Sacred' means set apart for a purpose. The sanctuary is set apart for the purpose of housing collective worship. This purpose requires certain physical conditions, which the architectural design provides, but its sacred nature is additionally made known through its symbolic form, clearly distinguishing it from the non-sacred. Churches are sacred not because the sites themselves are imbued with power, but because they are set aside for One who has power. ... They are not magical but they turn our mind toward things we otherwise tend to forget (even God Himself). They stand as a symbol of the holy, pointing their occupants to consider God." (Kramer 2005: 14-15)

Protestant spaces cannot be said to have been chosen because of heirophany, rather the space is chosen and set aside for heirophany. Therefore, the purpose of the architecture of the church is to mediate experiences of revelation and religious practices. However, because the mediation of such revelations occurs through material objects, then a broader interpretation of poetic space is required to understand the subjective process of sacralization of space.

In this chapter then, I expand the poetics of space to include personal as well as cultural meaning-making (Mazumdar \& Mazumdar 1993). In this way meaning making comprises not only the 'pure' subjective experience,

29 While Gell noted that though objects can be ascribed (divine) agency, it is not real agency in the sense of the word. Instead objects have a secondary agency in that the power they have to mediate social relationships lies in the meanings that they are given by their makers and users (Gell 1998; 1999). 
but also the cultural aesthetics and symbols which are involved in any materialization of the divine, as well as the meanings that are ascribed to place by individuals who are enculturated with particular cultural understandings of sacred space. Consequently, both historical and cultural symbols as well as the personal interpretation of such symbols produce poetic space (Brown 2004). So what historical and cultural symbols exist in the CICC church architecture to set them apart as sacred? And how do these symbols manifest in architecture of the church to mediate the experience of sacred space?

The production and reproduction of the CICC churches as a sacred space is informed by a traditional Rarotongan cosmology. As I explained in the Introduction and Chapter One, the locations of CICC churches were chosen according to cultural and political adaptations of pre-Christian spatial orientations by oromeuta, ariki, and mataiapo ${ }^{30}$. So while it cannot be said that a hierophany of a Christian sacred occurred in Rarotonga, it can be said that churches were deliberately constructed according to a pre-Christian heirophany (i.e. traditional Rarotongan concepts of sacred space). This is evident in the symbols of the church which retain some of the pre-Christian cosmology. For example, the seating of traditional leaders in the church corresponds to the dichotomies of the island and former marae (i.e. mountains vs. sea) and the location of the church on the ara tapu (sacred path) is in contrast to the marae on the lesser ara metua (ancient path) (Campbell 2002b; Siikala 1991; Sissons 2007).

Following on from the importance of the location, CICC churches are also separated from other spaces on Rarotonga. First and foremost, when one circles Rarotonga, it is easy to immediately spot the CICC churches which dot the island. In contrast to most other buildings on the island whose architecture is non-permanent - their roofs tethered down during cyclone season and the structures often decaying within the space of a few decades the coral limestone structures of the CICC churches stand out not only for

30 See the Introduction and Chapter One for more detail on the manner in which churches were situated within Rarotongan cosmology. 
their vast size but also for their solidity and durability; they are still standing over one hundred and seventy years later. The permanence of the building makes it exist within a sacred time; it connects the building with the past. The permanence of the building also makes it a timeless representation of Christianity $^{31}$. Thus, the materialization of the church makes it noticeably different from other places because it is constructed in such a way as to draw attention to and clearly set aside this space from the everyday, profane world.

Besides the physical presence of the church building compared to others on the island, CICC churches are also distinguished from secular buildings through their white washed walls ${ }^{32}$ :

Interviewee 5: "The church buildings represent the stability of the CICC. They represent that we believe in God, we have a home to worship him in and anyone who believes in him is welcome here. The white paint is a representation, a sign for anyone who loves God that it is a place for anyone who loves to worship God to come in."

This white paint has two purposes: it visually separates the church from other profane buildings while at the same time the white walls draw people in to entering the sacred space. It is a beacon for worshippers of the CICC as well as being a symbol for the congregation's adherence to the principles of Christianity.

Third, the space and place of the church is physically demarcated from the secular by coral limestone walls. These walls have only two to three gates that lead into the church, the most prominent being a path that leads straight into the church (Figure 5). By limiting the access to the building, the walls then act as a boundary that controls the entry into the sacred space of

31 The notion that the church is an embodiment of Christian history and a symbol of Christian cosmology is similar to the idea I raised in the politics of exile that the church is a representation of the collective Christian history of Rarotonga. See Chapter One for more detail.

32 The exception to this on Rarotonga is Titikaveka church, where the masonry has not been covered with white paint and the coral limestone technique because the ekalesia "wanted to remember the sacrifices of their forefathers who built it", including the vast manpower and many deaths involved in building the church (Field notes, 24 October 2010). 
the church, and consequently the assumption of a religious identity and personal engagement with the sacred space. The bell of the church plays a similar function to the church wall in controlling sacred boundaries by calling people into this sacred space for worship at the appropriate times:

Interviewee 7: The bell is important, especially to our people because they are church goers. It signals to them to go to church.

Interviewee 6: The bell rings three times. There is the $1^{\text {st }}$ bell, then $[15$ minutes later] the second bell, which is when you are supposed to go in to the church. It's a warning bell, and then there is the $3^{\text {rd }}$ bell when the minister and deacons go in the church.

Interviewee 7: But today everyone else is ministers too, they take their time to go in now. [Smiles]

Interviewee 6: It doesn't matter to me though. But on Penrhyn and the outer islands it's different, more traditional. On the $3^{\text {rd }}$ bell the doors are shut and you have to be inside before then. But here we level ourselves with the members of our church, which I believe in that way you can work together with them and be a good leader.

While the placement of the bell is not always within the clear physical boundary of the $\operatorname{church}^{33}$, its purpose is to regulate entry into that sacred boundary. By signalling the times for worship, it also signals to the community when religious practices and engagement with, or contemplation of, the sacred should take place. To be on the wrong side of the sacred/profane threshold (that is, in the profane) during this time is to be unChristian because the congregation and community view individuals as not involved in the communal rituals and practices of engagement with $\operatorname{God}^{34}$.

33 For example at Matavera and Titikaveka the bell was situated opposite the church, the road dividing them; this is in contrast to other churches like Nikao, Ngatangiia and Arorangi where the bell is within the wall boundaries and Avarua where the bell is within the church tower itself

34 In the outer islands, only the sick and elderly are excused from going to Church on Sundays. 


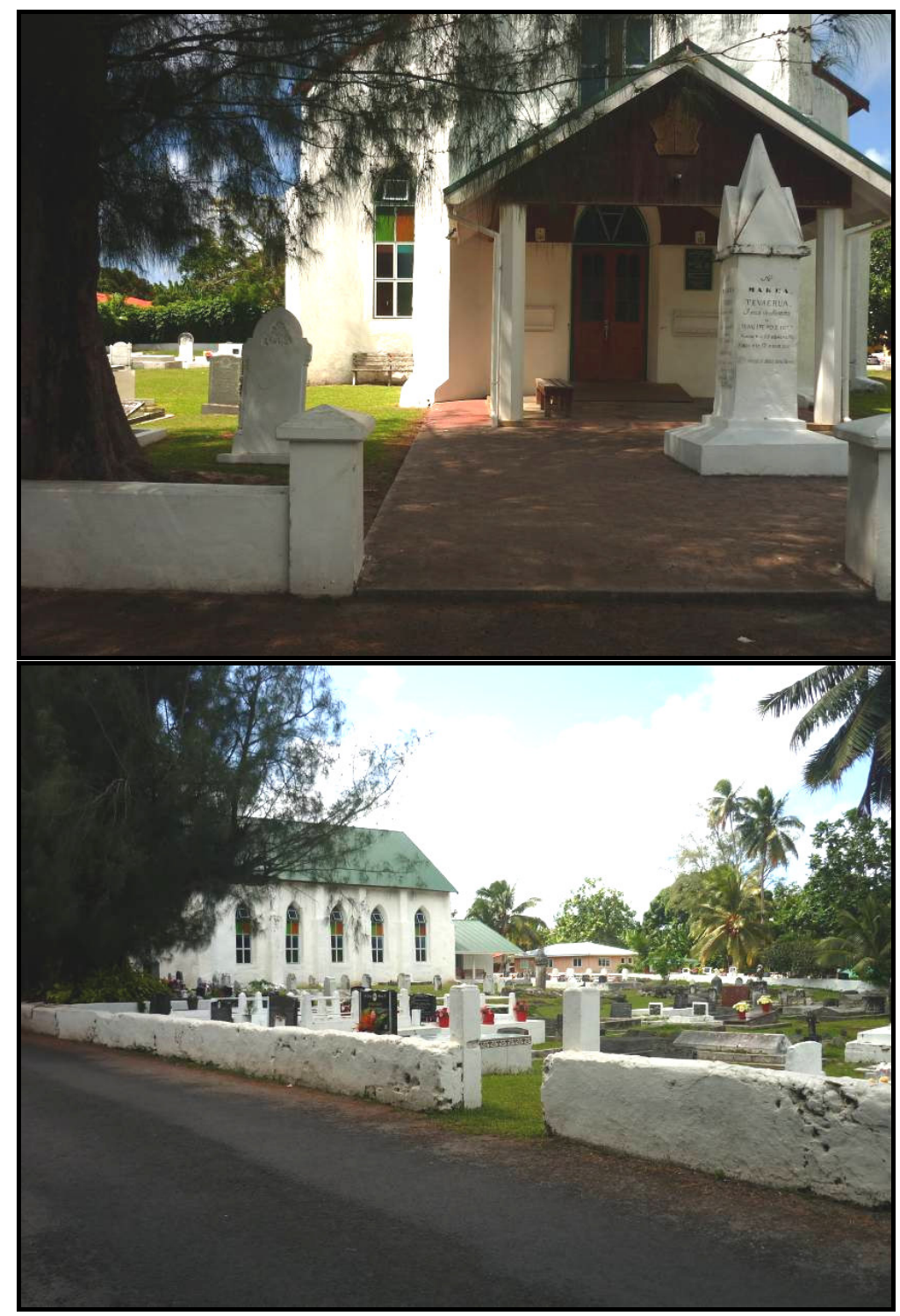

Figure 5: The two entrances in the boundary wall surrounding Avarua Cook Islands Christian Church.

Finally as one enters the church, the separation between the sacred and secular is marked through the signs on the front façade of the church building (Figure 6). At Avarua church, this is a sign above the threshold that reads "Ziona Tapu", differentiating the space that one is about to enter as sacred (tapu) from the space that has just been left. So the CICC churches are recognized as sacred and separate from the profane by individuals through their physical location, and through architectural symbols that represent a 
sacred time, a collective Christian identity, and which control religious rituals and practices.

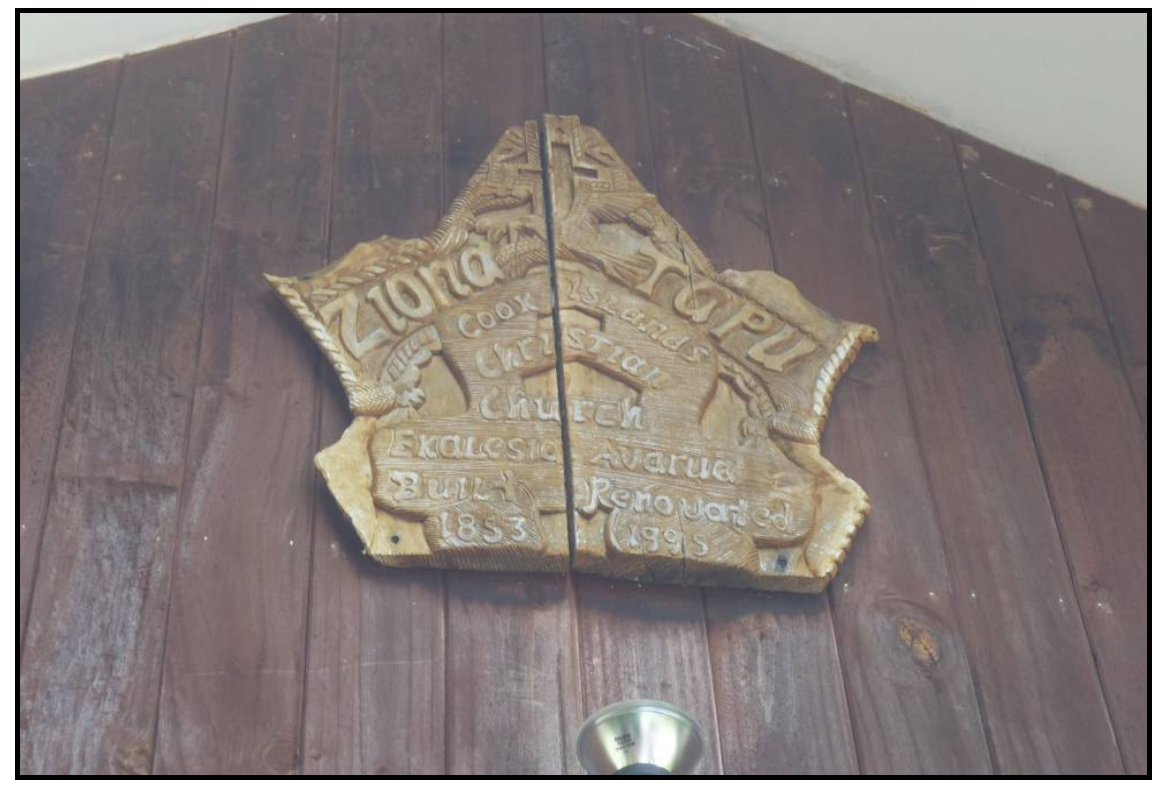

Figure 6: The sign Ziona Tapu above the threshold of the Avarua Cook Islands Christian Church clearly marks the church as a sacred space.

Externally the architectural features of the church distinguish it from the profane world in order to draw the congregation in to a space where they can contemplate the sacred. However internally, the purpose of the church architecture reflects the third aspect of poetic space. The interior of the church enhances those religious experience and rituals ${ }^{35}$ that maintain the sacredness of the space. Religious experience in the CICC is focused on aural senses; indeed during one of my interviews I was told that the outside of the church is considered interesting as it possesses more history and meaning than the inside, "because the inside is just to be comfortable to listen and worship" (Interviewee 3). Therefore, the interior architecture of the church is sparse compared to the heavy iconography of Catholic churches for example (Bowen 1998; Brown 2004). Nonetheless, the minimal internal architecture is designed in a manner that the high ceilings and structure of the church amplify the sounds of singing and traditional hymns (imene tuki), as well as

35 In Chapter Three I examine in more detail how performances enhance the experience of the sacred and how they produce sacred space. 
the orometua's sermons. The voices of ritual practitioners and the collective performance of singing resound around the chamber of the church making the wood vibrate and imbuing the space with an almost other-worldly power (Hale 2007). Therefore performance also enhances personal experience of the sacred.

Beyond the sensory features of the church architecture, there is one other interior feature of the church that is important to sacralization. This is the pulpit itself:

\footnotetext{
"Interviewee 7: The districts of the church each take turns cleaning and putting flowers out for the services, that kind of thing. The cleaning members don't go on the pulpit though. Only the elders or the reverend's wife goes onto the pulpit. Interviewer: Why is that?

Interviewee 7: Because it is holy. They think it is holy so they don't go up there."
}

The pulpit and the rooms behind the pulpit (the sacristy) where the Holy Communion is prepared are the epitome of the sacred within the CICC church because it is the physical place which mediates interaction with the sacred and where the sacred becomes real to the congregation through the word of the orometua (Figure 7). It is through the word of the orometua that individuals begin to contemplate God and it is the orometua that directs the service and when religious rituals such as prayer and singing will be enacted by the congregation, thus sacralizing the space of the church. Thus, experiences are filtered and controlled through architectural features that enhance the consideration of the sacred and in turn sacralize that space by concretizing religious rituals and personal experiences. 

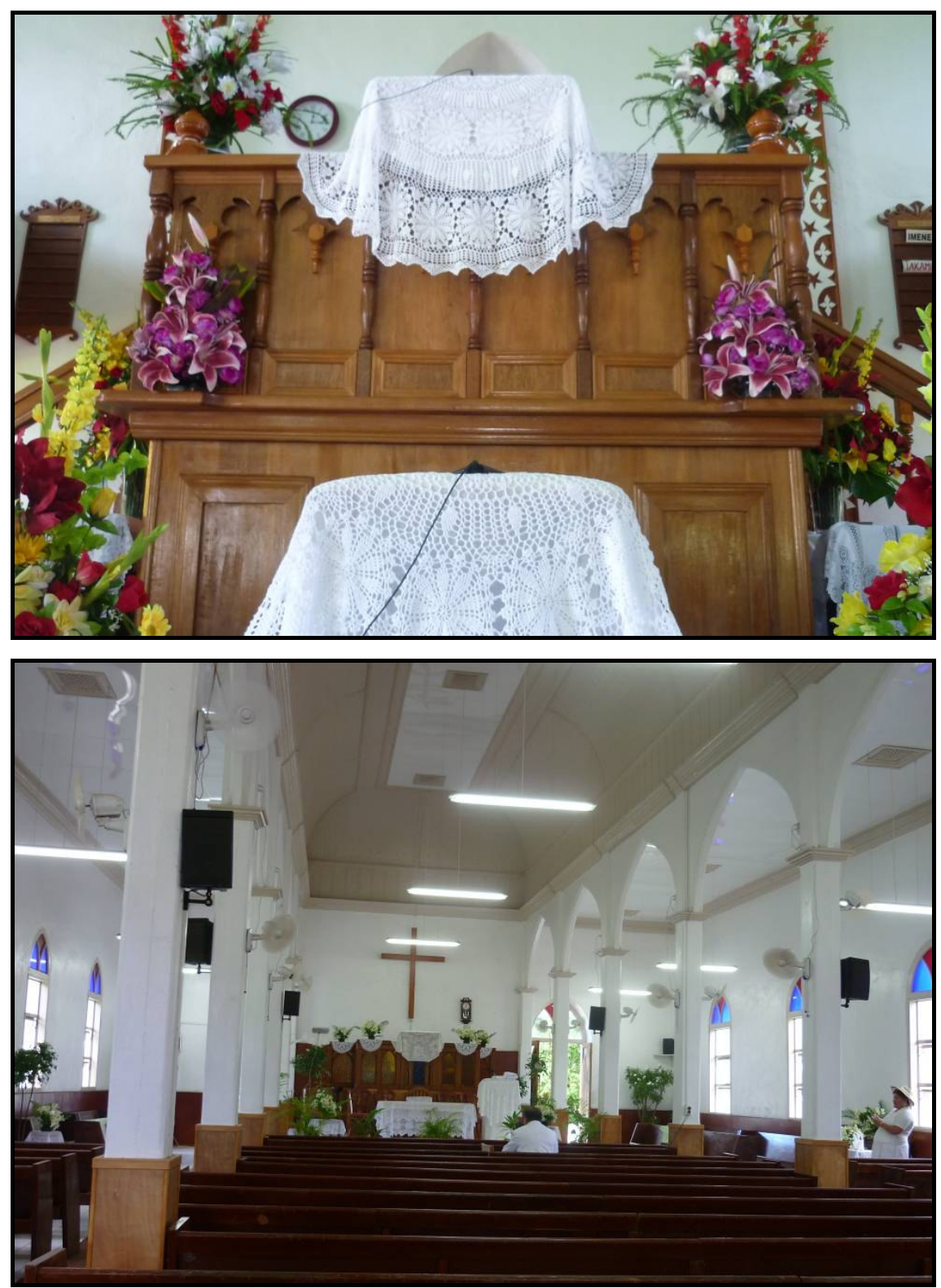

Figure 7: (Top) Pulpit at Avarua church in detail; (below) the pulpit at Ngatangiia church. Both are representative of the general configuration of churches on the island with a high pulpit from which the orometua preaches, and a lower pulpit or lectern which lay people (i.e. deacons, women, and youth) may use to read scriptures, lead the ekalesia in prayer, or to make general announcements.

In summary, the architectural features that I have described are more than just material things; they are also markers of the sacred, imbued with different meanings. Therefore, while there may be architectural variances between the CICC churches on Rarotonga, "What is important is that it [the church] is a symbol of the temple" (Interviewee 6, emphasis added). The 
architecture of CICC churches contain representations of God, faith, and the sacred as well as symbols that call worshippers into that sacred space. All of these architectural markers make the person aware as they near the church and eventually enter within its plane of sacredness, that they are entering a space which is different from the secular. In a sense, it is these architectural markers which make the building have its sacred power and with which a person interacts to give meanings of awe and sacredness to the building (Gell, 1998). Therefore, as long as the essential representations and symbols exist in the church, then nouminal experiences and sacralization of the space can continue to be made by individuals within Cook Islands Christian Church ekalesia. $^{36}$

\section{Social markers of sacred space: The production of sacred spatial orientations}

The previous section addressed the first three aspects of poetic space in which the space of the church is sacralized through the materialization of architectural markers (i.e. symbols) that differentiate the sacred from the profane. In this section I shall look at the final aspect of poetic space - the creation of spatial orientations based around those heirophanies. While the materialization of the sacred sets it apart from, and makes individuals acutely aware of the profane (Eliade 1987; Evans 2003), I would also suggest that spatial orientations cannot be distinguished as purely profane and sacred. This is a criticism that has been levelled against Eliade that classifying the profane as 'everyday' devalues it as a mundane space and takes the sacred/profane dichotomy too far (Holloway 2003). Consequently, "in the depiction of the profane as 'formless', 'nonreal', and 'homogeneous', the

36 For example Titikaveka church originally had a triple gabled roof which represented the holy trinity of God, Jesus, and the Holy Spirit. Because of maintenance, the roof was eventually turned into a single gable roof. However this was not contested by the congregation because the ekalesia "all have one God anyway" (Field notes, 24 October 2010). A parallel can be drawn with Chapter One here. Although the destruction of the graves was a clear change of the engagement with the sacred space, the change to the Titikaveka roof was not challenged because the essential meanings of sacredness and symbolism of God within the building remained, unlike the graves which removed the presence of symbols and meanings entirely. 
everyday becomes an inert force that has little impact upon sacred space other than through its denial" (Holloway 2003: 1962).

Yet there is an inter-relation between the sacred and profane. As Chapter One showed, religious spaces do not exist in a cocoon; they are in fact informed by social structures, practices, and knowledge/ideas that are constantly being produced, expressed, and transformed within this space (Chidester \& Linenthal 1995; Kong 2001; Knott 2005b). As I will show, the spatial orientation of the sacred is not purely dichotomous; rather the sacred and profane is a nuanced spatial matrix that feeds into one another through social norms and structures. In the following section I discuss two sorts of socio-spatial orientations of the sacred. The first orientation looks at the dialectic of how social organisation is imposed upon the architecture of the church and how social organisation within the church is sacralized to produce local socio-spatial orientations. The second orientation more broadly addresses how people locate religious places, and consequently their own social and religious practices, along a spatially sacred plane. Both of these spatial orientations could be called the social poetics of space as they look at the way in which individuals practice and construct their cosmologies and experience of sacred (and profane) spaces.

In the first spatial orientation, the social hierarchy of the profane world is expressed in the CICC through architectural symbols and religious practices. The social structures of the Cook Islands are expressed and directly replicated in the architecture of the church as a smaller representation of the social structure (Figure 8). ${ }^{37}$ For example at Avarua the front of the church is divided for the chiefs and sub-chiefs. The reason for this is:

Interviewee 5: "It's a system of honour because they gave the land for the church.... The missionaries were clever because they targeted the chiefs with their message and they tell the people what to do and they all followed"

37 Religious places have been noted as being a miniature representation of the wider cosmos (Bourdieu 1970). The structural representation of society within sacred spaces can be seen as a mirror to this approach of analysing sacred space. 
As mentioned in the Introduction and Chapter One when I described the historical ariki-church relationship, the seating of traditional leaders at the front of the church reinforces the tamaua relationship between traditional leaders and the church. It recognises that they played a pivotal role in the establishment of Christianity in the Cook Islands by providing land and supporting the conversion. Furthermore, although there was a transformation of traditional Cook Islands cosmology to Christianity, the pre-Christian spatial structures are still evident in the seating arrangements of traditional leaders - the hierarchically more powerful ariki sit on the seaside of the church (and consequently a more sacred position in the cosmology) while mataiapo sit on the mountain side (Campbell 2002b; Siikala 1991).

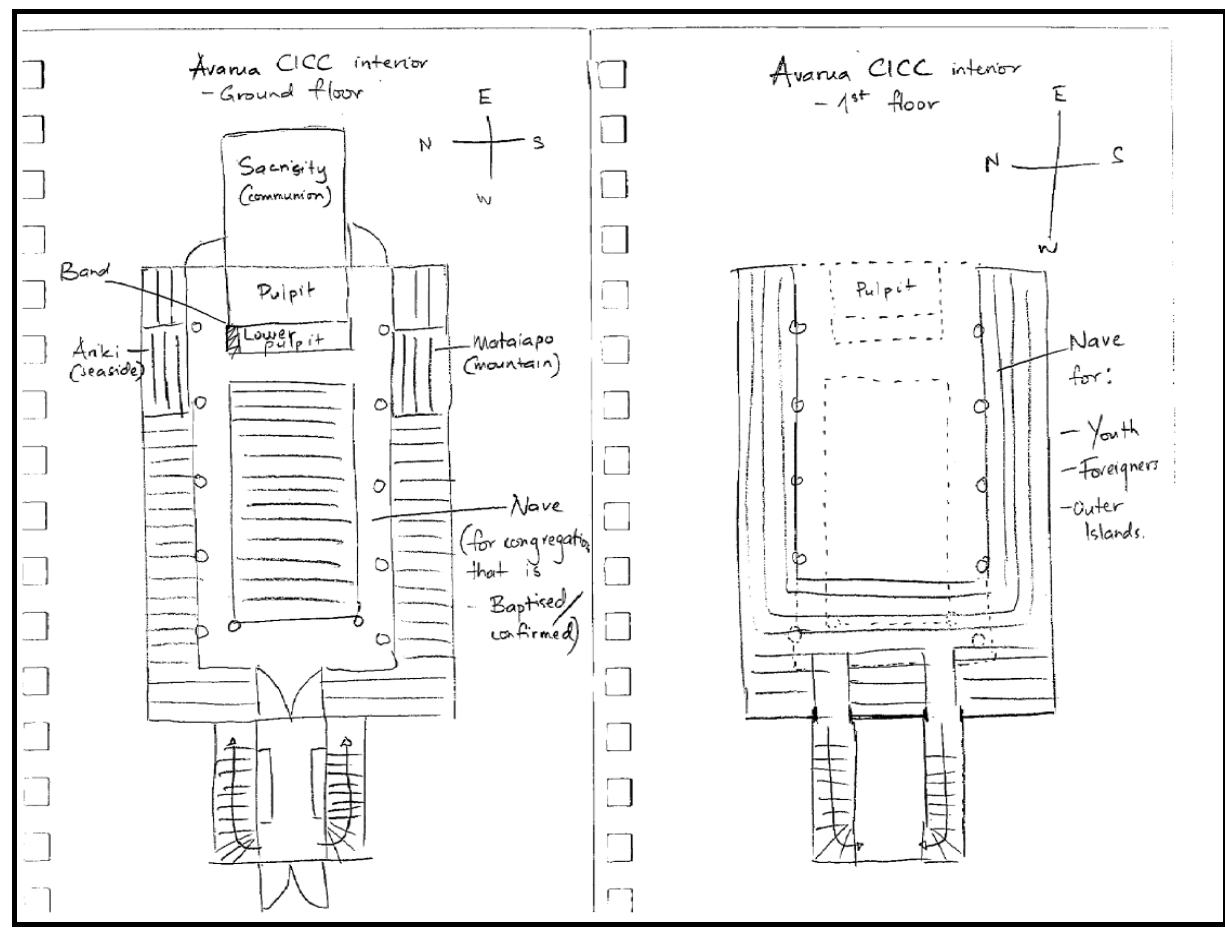

Figure 8: Diagram of Avarua Cook Islands Christian Church floor plan illustrating socio-spatial divisions. On the ground floor, ariki sit near the pulpit on the left side while mataiapo sit on the right. The rest of the space is divided according to subdistricts. The upper floor is where youth and foreigners sit (Field notes, April 2010).

The exceptions to this are Nikao church and at Titikaveka church; neither have a separate space for ariki because they do not have ariki in their districts. In addition, Titikaveka is unique structurally as only the choir has a 
separate space and the pulpit faces landwards, an embodiment of the history of development for this church, namely that the mataiapo gave up their rights within this space as it was recognized the church was an equalizing force. Despite this rhetoric of equality it was noted:

"Interviewee 5: Even though there is no representation for the ariki at Titikaveka, if they come to church and someone is sitting in their pew they get mad."

"[The speaker at the Titikaveka Sunday after-service] says that all sides of the church are equal because the entire congregation is equal. Yet he still acknowledges that there's a hierarchy because the front rows ( 3 rows in the middle), are set aside for the ariki and dignitaries when they come to the church." (Field notes, 24 October 2010).

Therefore the tamaua relationship, even if they are not explicitly acknowledged in places like Nikao and Titikaveka, are still recognised. In practice, the chiefs are also still recognised during the opening speeches at Sunday service (and in most formal non-church functions as well), as a sign of respect and deference to them as the "parent" of the church in the tamaua relationship (Lange 1997).

The architecture of the church also reflects the religious structure of the CICC. For example, the pillars within the CICC church often symbolize people who are important to the leadership of the ekalesia: at Ngatangiia church the twelve pillars represent the twelve deacons (Interviewee 4), whereas at the Titikaveka church, the eight posts represent the "eight mataiapo who renounced their heathen ways to become Christian" (Field notes, 19 October 2010). The space of the church also orientates the ekalesia according to social divisions that highlight the location, age, and gender of worshippers. The pews in the church are allocated to each of the sub-districts (Tupapa, Maraerenga, Takuvaine, Tutakimoa, Ruatonga, and Avatiu), their responsibilities for leading the hymns as well as cleaning and decorating the church divided and rotated between them ${ }^{38}$.

38 The famous "divided church" on Mauke is a very distinct example of how the CICC church can represent social organisation. The church is notable for the fact that when it 
The gender division within the church is emphasized by the roles that women and men play within religious rituals. For example, only orometua (who is always male) is allowed to preach from the pulpit:

"Interviewee 7: The lower pulpit is where deacons make their sermons from. And if women preach then we preach from the lower pulpit too."

Furthermore, in some instances the youth ${ }^{39}$, or more specifically those that have not had confirmation, are distinguished spatially from the rest of the church. At Avarua church the youth, along with people who do not belong to a village within the parish (such as people from the outer islands and tourists), all sit on the upper level of the church. Wherever any one sits though, the pulpit is placed in a way that the orometua (and thus God's) gaze is able to see all, exerting social control so that everyone behaves within the sacred space as one should and that everyone ritually engages with the sacred when they have to (Figure 9).

In ordering the seating of the church around social structures (which also exist outside of the sacred sphere in the profane world), the experience of the church is not only orientated around the sacred centre of the church (the pulpit), but also around the body. By this I mean that the social structures within the church control and order and individual's experience of the sacred space according to whatever gender or age group they belong to. For example, as a child moves from the upper floor to the lower floor of the church when they grow and receive confirmation within the CICC church, their experience of the space will also change and be reproduced according to the new roles and religious practices that they undertake. Consequently, the architecture of the CICC church materializes traditions and social

was being built, the two villages within the parish each nominated a designer for the church. However, when they could not decide between them who would build and decorate it, they each erected one half of the church instead. Each side of the church is decorated on the interior and exterior in their own way and to this day the villages still enter and sit in their own half of the church (Syme-Buchanan n.d.; Siikaala 1991).

39 I refer to youth here as children and teenagers. In the Cook Island Christian Church, the term 'youth' is used as a specific classification for those in the age group of 15-45 (Interviewee 2). 
relationships. The materialization of cultural traditions and social relationships within the space of the CICC church also sacralizes them through the ordering of religious rituals according to traditional social structures. This is evident in the roles that youth, women and traditional leaders play in religious practices.

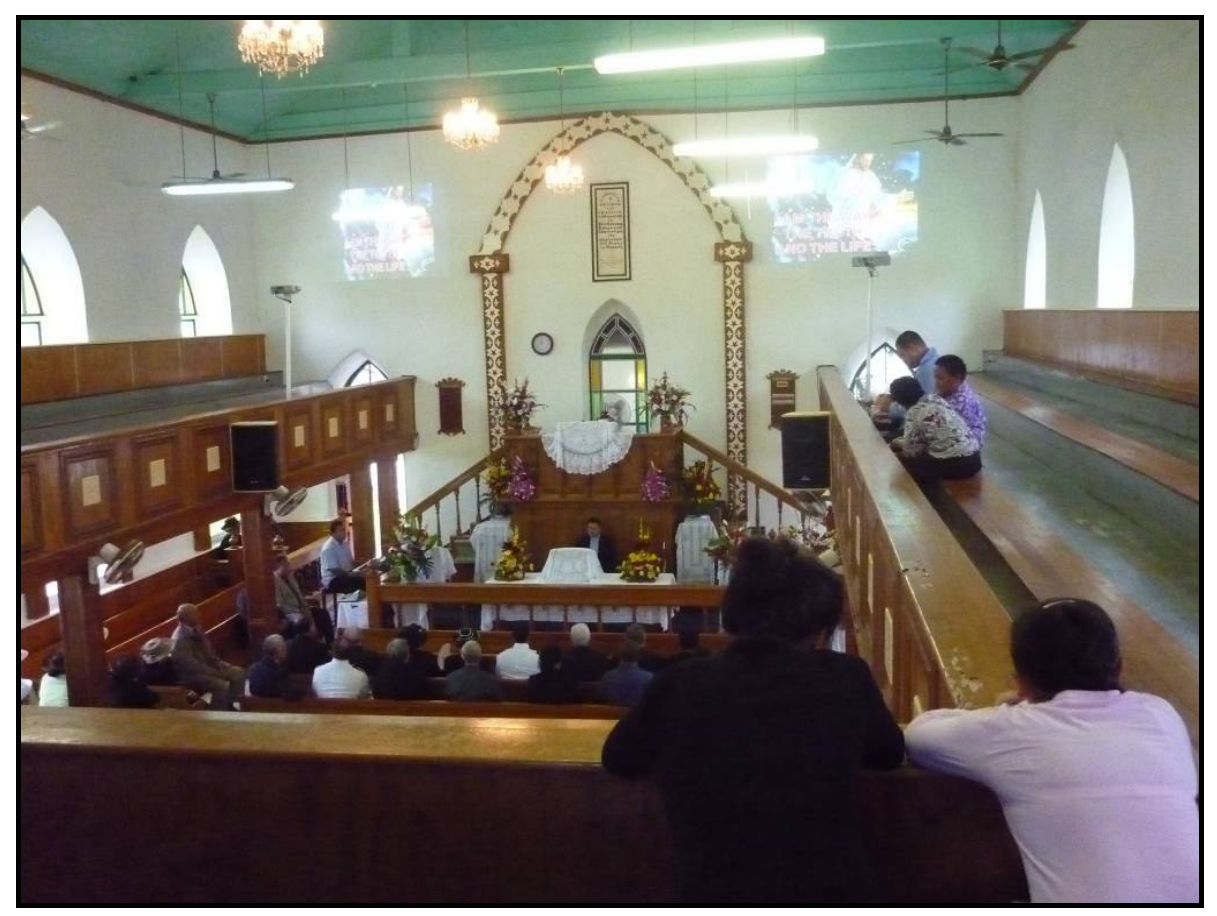

Figure 9: A view of Avarua church from the upper level. As this photo shows, the pulpit is clearly visible even from the upper level of the church.

As Eliade noted, the experience of the sacred establishes spatial orientation by "revealing a fixed point, the central axis for all future orientation" (Eliade 1987: 20; Altizer 1975). This is the second form of spatial orientation that I wish to address. The CICC is perceived as the sacred centre of space because it is the place that brings about the experience of the divine, and thus the understanding of the rest of the world. The sacred centre also orders everyday practices around it. I propose that this sacredness radiates out into the immediate space around it, diluting the further from this centre as it encounters profane spaces; every direction and place with its own level of accent or tonality of the sacred (Sack 1980). Therefore, the distinction between the sacred and profane becomes less apparent the further 
away one is from the sacred centre that is the church. Ritual actions and practices consequently are located on a cosmos of the sacred and secular, behaviour being differentiated according to the distance and location from the sacred centre (Shiner 1972).

In my interviews and fieldwork this view of the sacred and profane was constantly expressed by locating social practice along a "traditional" and "modern" spectrum. This was not only a behavioural dichotomy but also a spatial one. Firstly, there is a distinction between the places where practices of the church are carried out. The following exchange about traditional and contemporary worship highlights the spatial orientations within the CICC:

Interviewee 2: Each [youth] group have their own meeting houses because each village has their own meeting houses. That's where they normally have their own church services, and that meeting house is mainly currently used by the village when there is a political meeting, a community meeting, a family meeting. Are you from New Zealand? Interviewer: Yes, I am.

Interviewee 2: OK it's a bit similar to the marae, how the marae operates. Interviewer: It's kind of like a family meeting place?

Interviewee 2: Yeah. So that's where they, the youth in the villages, meet. But when it comes for everybody to come together we meet here at the Sinai hall which is just next to the church. That's our main meeting place for everybody to come and have our own activities.

Interviewer: The meeting house buildings themselves, what do they look like? Is there the same sort of importance attached to them as the church?

Interviewee 2: Yes. In the past the villages used to be controlled by the elders of the church, which was a huge influence from the elders of the church. So they built those meeting houses. Apart from that, instead of catering to the needs of the church, it also caters to the need of the village as well.

Interviewer: So it's kind of like the community and the church combined in one place?

Interviewee 2: Combined, yeah.

Interviewer: The Sunday service, the four o' clock one is that for youth?

Interviewee 2: Yes, the four o'clock is a contemporary worship. We decided we need to accommodate the needs of the young people. But it's sad; the church is 
holding on. It's supposed to be for young people, whatever they want but the church

is still holding on, in control.

Interviewer: What do you mean by that, control?

Interviewee 2: It's like they want a little bit of the old tradition, the way of worshipping.

Interviewer: Can you give me an example of traditional worship and contemporary?

Interviewee 2: It's like singing without the music; singing like the old traditional tune and having programs. Because in terms of contemporary worship it's up to you how you worship, whether you stand up and clap your hands. You notice in the church you hardly see people standing up and clapping their hands. We class this our traditional way of worshipping, which is good.

Interviewer: And where do you worship for the four o'clock service? Interviewee 2: In the Sinai hall. That's when we play the keyboard; we play the guitar, and have the young people singing, singing English choruses.

Interviewer: So why is it in the Sinai hall?

Interviewee 2: Because you are not allowed to play the thing (makes hand motions of playing a guitar) in the church, plus in the church over there, there are certain rules you have to abide by. That's why I said the old tradition. Sometimes tradition is good, but there is a line where you can draw.

This exchange illustrates the spatial order of the CICC church. The church itself is where the most "traditional" behaviour and rituals of worship and sacralization are carried out. This traditionalism is read within the boundary of a sacred time as well (i.e. timelessness); the behaviour is something that must be abided by because that is the way it has always been and it is the way the elders worship. The 'traditional' is contrasted with the Sinai Hall where 'contemporary' forms of worship are performed (Figure 11). This is distinguishable from the 'traditional' by the types of worship ${ }^{40}$ and the people who utilise the space for worship. For example, as mentioned in the above interview, the youth services held in the Sinai hall often use modern music like guitars, drums, and clapping and dancing to worship whereas such behaviour is forbidden within the space of the church itself because it is not perceived as traditional worship. This is further contrasted with the meeting halls that are used for the needs of the village as well as for church activities. The ordering then can be seen as a move from practices and

40 I expand on the performance and experience of space in Chapter Three where I will compare and contrast different types of religious practice to reveal these spatial orientations. 
spaces of the sacred (i.e. traditional) to practices and spaces of the secular (i.e. modern):

\begin{tabular}{|c|ccccc|}
\hline Location & Church & $\leftarrow \rightarrow$ & Church Halls & $\leftarrow \rightarrow$ & $\begin{array}{c}\text { Meeting } \\
\text { Houses }\end{array}$ \\
\hline $\begin{array}{c}\text { Perception } \\
\text { of space }\end{array}$ & Sacred space & $\leftarrow \rightarrow$ & Sacred / profane space & $\leftarrow \rightarrow$ & Profane space \\
\hline Practice & $\begin{array}{c}\text { Traditional } \\
\text { worship }\end{array}$ & $\leftarrow \rightarrow$ & $\begin{array}{c}\text { Contemporary/modern } \\
\text { worship }\end{array}$ & $\leftarrow \rightarrow$ & $\begin{array}{c}\text { community } \\
\text { practice }\end{array}$ \\
\hline
\end{tabular}

Figure 10: Diagram of sacred spatial and behavioural orientations.

The closer that the place is to the sacred centre of the church, the more that the practices follow an ordered pattern which is immutable, continuous with the past, and mediates experiences of a collective Christian identity. Thus, these spaces are considered wholly sacred whereas the further away these practices occur, the more the secular and profane crosses into the production of that space.

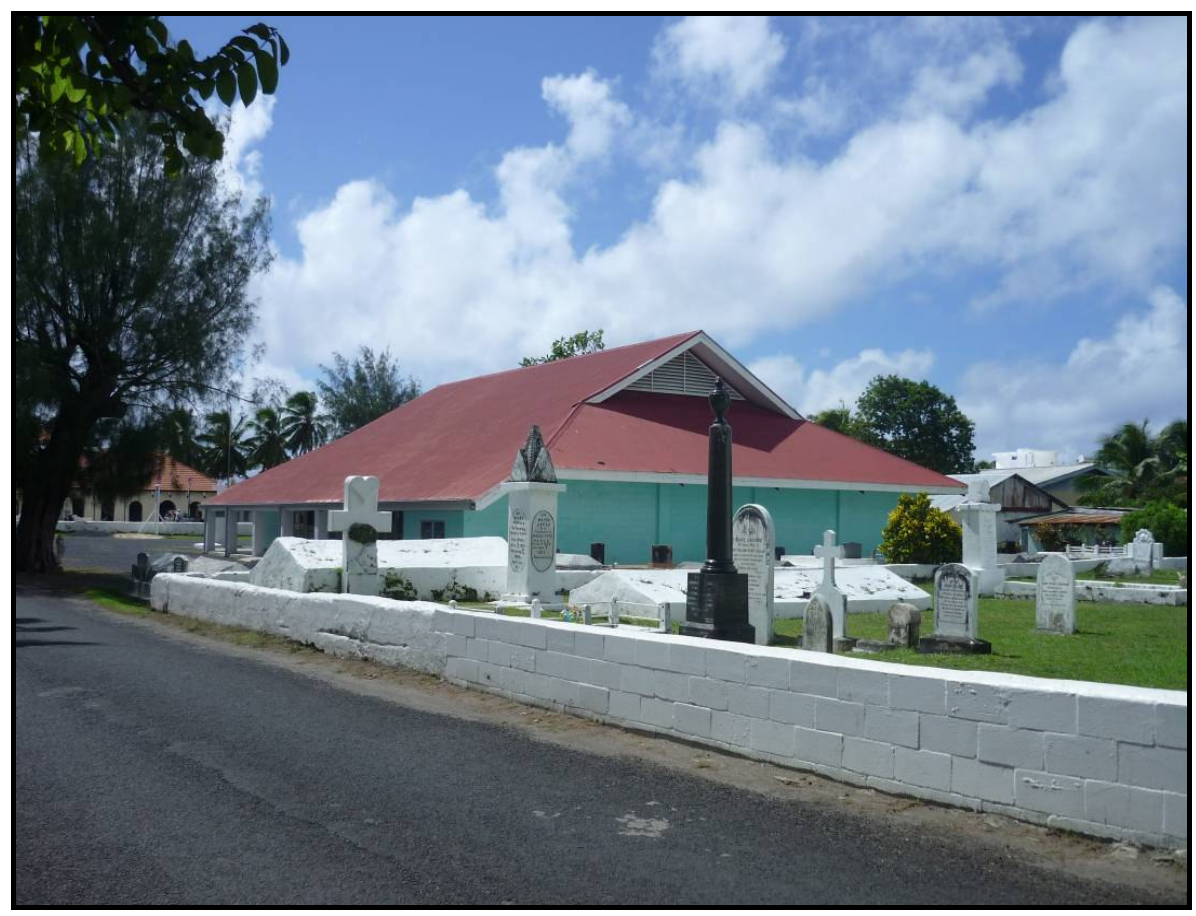

Figure 11: Pictured is the Sinai Hall which is used for youth services and contemporary forms of worship. It is located to the left and outside the boundary wall of the Avarua Cook Islands Christian Church. 
Secondly, the movement from the sacred to the profane is located along a larger symbolic spatial platform. The 'traditionality' of behaviour in the outer islands was constantly contrasted to the secularity of Rarotonga:

Interviewee 3: "The idea that tradition still governs very much what you do is true, especially in the Northern groups. In the Northern groups you have to be there before the pastor arrives, if you aren't there then you can't enter once the service starts and the doors are shut. The church is also very disciplining, and you can see it in the way that the kids are disciplined to sit still and to behave. ... You can see the traditional ways of worshipping influence aspects of the community. In Rarotonga you can see the difference between the lack of discipline from the church, compared to the Northern groups. In the Northern groups there is a 'strictness'. They are very set in their ways and beliefs, no matter what the pastor says to them they hold on to them, they are very stubborn."

Interviewee 5: "They say 'this is what our forefathers believed!' (shouts). They find it hard to let that go."

During this exchange the interviewees also had this to add:

Interviewee 3: "The church is an important organising structure in the outer islands, it is disciplining. When [people from the outer islands] move here they can hide away from the disciplines of home, and of course, everyone else isn't going on Sundays either. But a lot of them are immersed in the church at a young age so they have that continuity throughout their lives growing up, whereas here in Rarotonga you have difficulty in even finding people to continue singing the traditional hymns. There they are very good speakers and singers, and you can see in the kids here they aren't as confident in speaking.

Interviewee 4: There people live as a community therefore you can't do anything wrong".

The closer one is to the sacred space of the church, the more of an influence it exerts over behaviour because there is an awareness of the gaze of the church which is reinforced by the community. The "traditionality" or lesser influence of "modernity" and the outside also have an influence on how spaces are enacted: 
"I spoke to [one of the hostel caretakers] at dinner about how there weren't that many people at the Ngatangiia church service today. He replied that "there is a lack of people going to church". He believes that it's to do with parents because they don't take their children to church with them every Sunday. Some leave them [their children] at home and they go to church but "if you not take your kids to church they don't go when they are older because they don't know they have to go, that they have this thing of going every Sunday". So he said when they grow up they don't go; they only go on special occasions or once a year. He contrasted this to Penrhyn where they did not used to have entertainment so they went to church every morning. "Our parents would come and say 'wake up, you've got to go to church' and you do go to every service there. We went to 2 mornings and 3 every Sunday. But here I'm a bit too lazy to go to the morning ones". When I asked him why it was, he said 'It's in the mind. There [Penrhyn] it's in your mind to go to every church service". But here in Rarotonga, people have other things on their mind so they don't go to church. "It's all in the mind."” (Field notes, 02 May 2010)

So the larger the population and the space in which the church is located, the less it can exert its field of sacredness because the presence of the CICC is far less visible to Cook Islanders. This is evident as even though Rarotonga was seen as becoming more modern and less Christian, it was still seen as more Christian (and thus sacred) than overseas:

Interviewee 6: In New Zealand it was hard [to do missionary work] because we found it hard to support our family.

Interviewee 5: Here we all have the church, the missionary house, but there you have to find a place to stay, (...) and the members of the church are suffering with their own families too.

Interviewee 6: In New Zealand less people go to church because they have too many commitments to support their families, they have to work. But Sunday in the Cook Islands though is a church going day. It is a holy day for the family.

As this quote illustrates, the mobile population of the Cook Islands (i.e. that there is movement between the islands and overseas) means that the church no longer exerts as much influence on the daily lives of people. Therefore, it cannot teach the values of community and social practice as the church does in Rarotonga due to the competing values of Western and secular society. 
In addition to the movement of Rarotongan's outwards to the secular, there is also a movement of the secular towards Rarotonga. This dilution of sacredness through space was perceived as a result of the profane slowly impinging upon the behaviour, and thus space, of the sacred:

Interviewee 3: "I think those people want to maintain the idea of a Christian country because there are more immigrants coming into the country so we tell them this is God's, Basileia!"

Interviewee 5: "We believe in one way or another that we are a Christian nation, at least in word..."

Interviewee 4: "But we don't practice it"

Interviewee 5: "If people practice, then maybe it would be effective to say that we are a Christian nation, and we have that mana ... Tourism is good, but it also brought activity that affected the Sunday services and made it lose its tapu. Thirty years ago, the CICC was the only church with two services on a Sunday, but most churches now only have one service as an accommodation to tourism. In Sydney, Brian Houston [an Australian Pentecostal church pastor] has seven (holds up fingers) services a Sunday. Why can't we have that? But we don't have that; the rest of Sunday is a picnic day, a beach day. There are more families at the beach than in church; the concept of going to church is not in their hearts."

Interviewee 4: "You see more people going to a funeral than a service!"

The above interview highlights how Cook Islanders view the secular encroaching on the sacred space and practices of the CICC. In particular, tourism has become the livelihood for many people on Rarotonga, however, many people become influenced by outsiders who bring all the practices of a less sacred, modern world to Rarotonga. This shows that the dialogue and reproduction of the spatially sacred plane is two-way. In other words, because people work on Sundays to accommodate tourists they are losing their Christian values and engage less with sacred space. At the same time, the church becomes more tolerant to this behaviour and the lack of presence in the church by its parishioners on Sunday. Additionally, it was perceived that the lack of transformation and continued practices associated with the past (i.e. tradition) is also what is sadly causing CICC attendance numbers to drop. The youth are perceived as leaving the church because the CICC are not addressing the contemporary needs of the worshippers. 
Yet, ultimately the profane is expressed within the sacred too. For example, the maintenance of the traditional and sacred is something that is only achieved through the exertion of social control by elders and church leaders whose authority often extends outside of the church sphere as part of a non-sacred social structure. In turn, as mentioned in the discussion about the previous spatial orientation, these profane social structures are expressed in the CICC church through architecture and religious practices. In addition, by locating oneself on this spatial plane of sacredness, people are also identifying their own level of sacrality and sacred behaviour. How present and visible the church is in a community, the more sacred and Christian their practices of behaviour are perceived to be. So to be from the Northern group is to be more traditional and thus more sacred than those on Rarotonga and so forth. Furthermore, like the spatial orientation of behaviour and social structure, space is ordered according to a wider dialogue of modernity and traditionalism. This spatially sacred plane can be described as follows:

\begin{tabular}{|c|ccccc|}
\hline Location & $\begin{array}{c}\text { Northern/ } \\
\text { outer islands }\end{array}$ & $\begin{array}{c}\text { Southern/ central } \\
\text { islands }\end{array}$ & $\leftarrow \rightarrow$ & $\begin{array}{c}\text { Western } \\
\text { countries }\end{array}$ \\
\hline $\begin{array}{c}\text { Perception } \\
\text { of space }\end{array}$ & Sacred & $\leftarrow \rightarrow$ & Profane/ Sacred & $\leftarrow \rightarrow$ & Profane \\
\hline Practice & Traditional & $\leftarrow \rightarrow$ & Traditional/Modern & $\leftarrow \rightarrow$ & Modern \\
\hline
\end{tabular}

Figure 12: Diagram of sacred/profane spatial orientations in the Cook Islands.

This spatial orientation I have described is reinforced by the notion that the Cook Islands are perceived as "basileia" (kingdom of God). Rarotonga is the site of the oldest theological college in the Pacific and is responsible for training the many Cook Islander orometua who went out into the Pacific to spread the Gospel, particularly to Samoa and Papua New Guinea ${ }^{41}$. As a

41 The influence of the Cook Islands expanding their practices of Christianity throughout the Pacific is particularly evident in Papua New Guinea where the Cook Islands traditional hymns (imene tuki) have been exported and adopted by the locals (Stillman 1993). 
result, the Cook Islands can also be seen as the sacred-most centre of a Christian Pacific which slowly radiates out and interacts with profane space.

To summarize, because the 'everyday' and social is carried out in the profane it means that when the social moves into sacred space through architecture and practices, it brings profane practices and conceptions of space with it too. Therefore, the spatial orientations produced by the CICC church is dependent on the extent to which religion sacralizes a society's traditions through ritual and architecture, and the extent to which the profane is materialized within a space through practice and cultural symbols. Finally, the CICC church is an important structure to Cook Islanders as it is both a spatial and behavioural reference point. The church's role in the order of spatial orientations allows people to anchor their differentiations of behaviour and practices according to the sacredness of space that they perceive they are in.

\section{Conclusion}

In conclusion, by looking at the poetics of space as a personal and social construction, revelations are based on the power of not only experience but also cultural symbols and ritual practises. In this chapter, I illustrated how the Cook Islands Christian Church has architectural markers which differentiate it from secular space and which enhance the characteristics and symbols of the sacred. However, because the architectural must be rooted in the social - through both the meanings attributed to it as well as being a space in which practices (itself a social thing) of the sacred are carried out there are also social markers of sacred space. Therefore, spatial orientations and spatial practices do not exist along a pure sacred and profane dichotomy. In fact the lines between the two are often intermingled and one reaches into the other. While there are clear physical markers of sacred space and practice, there are also symbolic markers that require a deeper knowledge of the meanings behind Christianity and require an interpretation of the church architecture. The church not only mediates social interactions and orders 
practices of worship through architecture that elicits a response; it is also culturally constructed through traditions and knowledge. Therefore the production and reproduction of sacred space is dialectic in that religion is both represented within the symbols of the church, which in turn are embodied and internalized through practices.

An additional point that was raised, and which I shall expand upon in Chapter Three, was the role of practice. It was shown that practice, like architectural symbols, materializes the subjective experience of sacred space. Practices show how and where behaviour is enacted in relation to sacred and profane constructions of space. Furthermore, the politics of space introduced in Chapter One continued to play a role in the poetic production of space. The historical narratives and social relationships (e.g. the tamaua relationship) found physical and symbolic expression within the CICC church also ordering how individuals experience space. 


\section{Chapter 3: The Practice of Space: The Spatiality of Performance and Performing Sacred Space}

\section{Introduction}

The previous two chapters focused on the sacralization of space through the established lens of political and poetic production of space. In Chapter One, I showed that the politics of space sacralizes a place by consciously constructing what the sacred means and where that sacred should be established. Additionally, the discourses used to construct the sacred are controlled and negotiated by various social groups. In Chapter Two, I showed that the poetics of space sacralizes space by embodying revelations of the sacred/divine and feelings of awe. Although this is a subjective sacralization, once the sacred is materialized, the architecture of the church creates a sacred spatial and behavioural reference point that mediates how and when a subjective experience of the sacred is enacted and internalised.

Although practice is implied in the modes of spatial production mentioned in the previous two chapters, in this chapter I wish to look more closely at practice and performance as a mode of sacralizing space in its own right. Performances produce space by being a receptacle of cultural discourses (i.e. the politics of space) and materializing experiences of the sacred (i.e. the poetics of space). However, I suggest that performances also produce sacred space by helping individuals to embody sacred spatial distinctions and cultural meanings of sacred space. In this chapter then, I firstly lay out a spatial performance framework. Secondly I shall illustrate how this framework can be used to analyse spatial production by focusing on two of the more obvious forms of religious performance in the Cook Islands Christian Church - Sunday worship and religious pageants - to highlight the 
manner in which sacred space is produced, enacted, maintained, and understood through practice and performance.

\section{The Performance of Sacred Space}

As I mentioned in the literature review in the Introduction, there is very little scholarship about how practice and performance directly affect spatial production (Brace et al 2006; Jones 1993; Knott 2005a; Lefebvre 1993; Lawrence \& Low 1990; MacDonald 2002; Shiner 1972). However, it is undeniable that performance is part of the sacralization process. In this chapter I want to emphasize that performances are "ritual-architectural events" whereby physical place and performance interact with one another to produce sacred space (Jones 1993).

The interaction between performance and space is two-fold. Performances are the means by which the discourses and knowledge associated with the sacred are given form and invested upon a place and its architecture. (Chidester \& Linenthal 1995; Eller 2007; Lawrence \& Low 1990). As Kim Knott stated "Sacred space is not the stimulus for ritual; ritual, as sacred-making behavior, brings about 'sacred' space. Ritual takes place, and makes place in this sense." (Knott 2005a: 43, original emphasis)". Additionally, performances reinforce the experience of a place as sacred (Eliade 1987). Because performances naturally have to be enacted within a physical location, that place acquires meanings and symbols about the sacred (Lawrence \& Low, 1990). This is because over time, places and architecture come to concretize the sacred meanings, relationships, social dramas (Turner, 1974), and symbols enacted during a performance. Or to put it another way, performances produce sacred space by inserting structures and discourses (politics of space) into a place. Performances also produce sacred space by reflecting the existing meanings and symbols of a place (i.e. poetics of place). So how can the relationship between space and performance be further understand? Let us now turn closer attention to the process of performance and space. 
Firstly, I propose that the sacralization of space can be brought about by those implicit and informal practices which are embedded in everyday life and which give individuals a continuity, cohesion, and competence in the space of the Cook Islands Christian Church (Knott 2005a). For example, in the CICC, informal practices include gestures (e.g. knowing where to sit within the space of the church) or restrictions on dress and behaviour (e.g. women must wear skirts and baptised women must cover their hair with a hat) within the space of the church. In other words, performances are expressions of Bourdieu's “habitus” (Bourdieu 1989; Fowler 1996; Lawrence and Low 1990) ${ }^{42}$ - they constitute a form of embodied knowledge, a practiced knowledge (dispositions) so that individuals can perform the necessary actions for worship within the sacred space of the CICC.

Secondly, sacralization of space can be brought about by more explicit and formal practices. Explicit practices are more akin to what Milton Singer called 'cultural performances' which for the purpose of this thesis I shall call 'religious performances' ${ }^{43}$ (Singer 1972, Beeman 1993). Cultural performances tend to be the most prominent performance contexts within a community and can be defined as consisting of the following elements: 1) they are scheduled; 2) they are temporally bounded; 3) they are spatially bounded; 4) they follow a programme; 5) they are viewed by an audience or have collective participation; and 6) they communicate cultural themes and values, processes of social and cultural change, and they are not only reflections of a culture but also "agencies of change" (Beeman 1993; Turner 1988: 24).

42 Habitus is "a generative and structuring principle of both collective strategies and social practices" (Lawrence and Low 1990: 469). Habitus reproduces existing structures and in turn the dispositions and social practice is informed by organizing structures. Therefore habitus, like the dialectic of space that I discuss in this thesis, is both a product and producer of structures.

43 I use the term religious performance instead of cultural performance because it causes less confusion about the purpose of these performances (i.e. to sacralize space and reinforce religious values). This term does not change the underlying element of performance as cultural performances are simply spatial practices transformed by religious meanings and contexts (Knott 2005a) This is true of the ethnographic examples that I present in that both are ordered by the Cook Islands Christian Church, and additionally, the spatial production that arises as a result of these performances is inherently centered on the Christian sacred. 
The examples of cultural performance I provide in this chapter can be grouped into two further "genres": ritual performance and theatrical performance (Beeman 1993; Eller 2007; Turner 1988). Sunday worship in the CICC is an example of a ritual performance: "In ritual, the chosen practices are repeatedly performed, often memorized to near perfection. In some ritual traditions, mastery and exactitude are essential for the ritual to be efficacious, and their achievement creates 'expert' practitioners". (Knott, 2005a: 43$)^{44}$. The religious pageant of $N u k u$ is an example of performances of theatre and spectacle. The criteria of theatrical performances are that the purpose of the plays is for entertainment, the role of the audience is that of an observer and evaluator, and the performers are representing a symbolic reality (Beeman, 1993; Turner 1988).

Using the above definition of "cultural performance" as a starting point for a spatial-performance framework, there are two aspects of spatial production that I shall focus on in this chapter. Firstly, there is the spatial boundary of performance (the third aspect in the cultural performance definition). By this I mean that the genre of performance naturally limits it to being performed in particular places. I term this spatial boundary the spatiality of performance; it relates to the purely physical location of performance and the reasons a genre of religious performance is enacted in that exact locality. I will show that the two most prominent religious performances within the CICC - Nuku and Sunday worship - are spatially bounded by different places because of the structure and purpose of the

44 As Slough (1996) has shown, adding Ronald L Grimes' classifications of a ritual considerably expands the activities and experiences that can be classed as rituals. For example, hymns do not reenact a story or rite as classical definitions of ritual would have it, yet they still possess many of the other qualities of rituals, such as structure and repetition. Likewise, as a religious performance hymns are an extremely important mode of sacralizing and producing sacred space even though they are not as overt as other rituals in Sunday worship such as sermons. Therefore following Grimes' definition, ritual may include some or all of the following characteristics: 1. Performed, embodied, enacted, gestural; 2. Formalized, elevated, stylized, differentiated; 3. Repetitive, redundant, rhythmic; 4. Collective, institutionalized, consensual; 5. Traditional, archaic, primordial; 6. Valued highly or ultimately, deeply felt, sentiment-laden, meaningful, serious; 7. Condensed, multilayered; 8. Symbolic, referential; 9. Dramatic, ludic (playlike); 10. Mystical, transcendent, religious, cosmic; 11. Adaptive, functional; 12. Conscious, deliberate. (Aune 1996; Slough, 1996) 
religious performances that are carried out, and because of the perceived sacredness which has already been established around the church through time. Therefore, the places where particular genres of performance are enacted begin to reinforce the construction of sacred space.

Secondly, religious performance sacralizes space through the religious and cultural meanings of sacredness that are transmitted through performance $^{45}$. I shall show how religious performance produces and reproduces sacred space by sensitizing the audience to the difference between sacred and profane place. I call this communication of spatial values performing sacred space. The communication of spatial values occurs through the symbols and cultural meanings that are enacted in performances and through the reinforcement of spatial values by the collective experience of religious performances. Furthermore, by re-enacting religious performances on a regular basis, and in particular locations, the meanings associated with performance and spatial distinctions are embedded over time. In other words, religious performances are equally sacralized because of the religiously meaningful locations in which they come to be enacted.

Consequently, as the spatial-performance framework will show, the process of sacralizing space occurs through a dialectic of performance. Religious performances sacralize space through the cultural meanings that are communicated through performance. In turn the religious performance becomes sacralized through the religiously meaningful places in which the performance is bounded and enacted (Knott 2005a). In other words there is a clear reciprocal relationship between performance and space which produces sacred space. It is this relationship and interaction between location and meaning in religious performances, and their simultaneous production of one another, which I suggest is the third mode of sacralizing space.

45 In this spatial-performative framework, the other aspects of Beeman's (1993) definition of cultural performances, temporality, programmed nature, and audience participation (aspects one, two, four and five) are, I propose, a means to culturally transmit and receive the values of sacred space. 
Using the spatial-performance framework I have laid out above, I will now compare and contrast the two different genres of performance and practice in the CICC in order to analyse how sacred space is produced through performance in the Cook Islands.

\section{Sunday worship: A ritual performance}

The Sunday service for worship is the main ritual performed in the CICC. It is programmed and structured - worship is performed at set times during the week. There are two morning services on Wednesday and Friday at $5 \mathrm{am}$ and Sunday has three services at 5am, 10am, and 4pm. There is a monthly order to every Sunday service as well with a different social group (e.g. youth, 'Evangelists') within the CICC leading each service (Interviewee 2). There is also a set order to each service. For example, the Avarua Church Sunday service followed this basic structure each week:

- $\quad$ Introit

- Notices

- Collection

- Dedication of offerings

- $\quad$ First hymn (imene apii sabati)

- Prayer of confession

- Lord's prayer

- $\quad$ Bible reading

- $\quad$ Imene Tuki

- $\quad$ Prayer of thanksgiving

- $\quad$ Imene Tuki

- Hymn by individual singers

- Sermon

- Vesper/final hymn

(Field notes, April 2010)

Moreover, each member of the congregation is expected to take part in the collective ritual performances of Sunday services. For example, as I observed, the Sunday scripture at Avarua Church was always read aloud by the congregation in unison with the orometua, the Lord's Prayer was always sung together as a congregation, and hymns especially were a prominent 
element of worship within the CICC service with particular hymns (e.g the Introit) performed in every Sunday service. Hymns can be distinguished between those that follow the Western European structure and tunes such as the imene apii sabati, compared to the so-called 'traditional' hymns, imene tuki. These latter hymns are most notable for their lack of musical accompaniment and their four part harmonies, which are unique for the deep grunts of the men and the high notes (pere pere) of the women (Niles, 2000; Stillman 1993). Although both forms of singing are acceptable within the space of the CICC, the imene tuki is more so because it is the "way that our ancestors used to sing" prior to the Missionaries; the traditional tunes and patterns having been adapted to a Christian setting (Field notes, 25 April 2010).

Finally, the orometua, as the ritual practitioner, is the centre of the service. He preaches the sermons and the word of God each week from the most sacred spot within the church - the pulpit ${ }^{46}-$ thus concretizing his special status within the ritual of Sunday worship. Together, these performative elements comprise a uniquely Cook Islands mode of Christian rituals of worship and performance of the Gospel.

\section{The spatiality of ritual performance}

The "traditional" rituals of Sunday service are enacted within the physical space of CICC churches. But why is this? As I mentioned in Chapter Two when I discussed the poetics of space framework, the purpose of Sunday worship in the CICC is to bring one closer to God (Kramer 2005). Therefore, it is no surprise that rituals of worship are performed in those spaces that are set aside and demarcated as the most sacred. As I illustrated in that chapter, the architecture of CICC churches help to demarcate the sacred from the profane, this spatial separation also regulating the entrance into sacred spaces and regulating the commencement of ritual performances. For that reason the material structure of the church not only binds ritual performances to a

46 As mentioned in Chapter Two, I located the pulpit as the central architectural marker of the sacred within the church. 
particular location, the spatial boundaries of that location also help to reinforce the structure of ritual performances by ensuring that the performances remain highly timed and organized. Furthermore the walls of the church ensure that ritual performance is enacted - the solidity of the walls closes all members of the congregation within the space, ensuring that they partake in collective rituals of worship and spatial meaning-making. This is stark contrast to rituals on marae, or even the Nuku I mention below, where individuals are not bound to stay within a particular location during the performance.

Aside from the physical structure within which ritual performances are enacted, spatial orientations are equally important to the spatiality of performance. As shown in the previous two chapters, the location of churches, and thus location of ritual performances, developed according to particular historical cultural norms and which have over time become cemented as a sacred space used exclusively for ritual performances. For example, as I mentioned in Chapter One, traditional leaders gifted land for the establishment of CICC churches. In doing so they approved the new Christian structures and rituals while maintaining authority over how those practices were enacted (Lange 1997). In fact this tamaua relationship between church-traditional leaders continues to be recognised spatially by distinguishing where traditional leaders sit from the rest of the congregation.

The location of churches was also consciously selected according to the established cosmology of sacred space in Rarotonga (Campbell 2002b; Sissons 2007). Churches are located within the most sacred section of preChristian constructions of space: they are more often than not situated near the coast and lie outward of marae on the more sacred path of ara tapu (Campbell 2002b; Sissons 2007). As shown in Chapter Two the experiences and cultural orientations created around the church developed into new 
spatial planes of sacredness where CICC churches are the sacred centre of space; the power of the sacred diluting the further away one moves ${ }^{47}$.

Aside from the physical structure within which ritual performances are enacted, the aforementioned spatial orientations are equally important to the spatiality of performance. This is because once the space of the church is perceived and constructed as the most sacred within a CICC spatial cosmology only certain genres of performance can be enacted within that space. In the space of the CICC only those ritual performances and implicit behaviours classed as "traditional" can be enacted:

"Interviewee 2: ... plus in the church over there, there are certain rules you have to abide by. That's why I said the old tradition. Sometimes tradition is good, but there is a line where you can draw.

Interviewer: Can you tell me what some of the rules are? Interviewee 2: Over here you have the attire wear. So you see the ladies with the hats. Once you become a member you must wear a hat. Once you become a deacon, you must wear a suit and a tie. And women are not allowed to wear shorts or long trousers; they must wear skirts or a dress. And when you come in, you are not supposed to walk into the church when the service has started. If you are late then you can't enter the church except during the singing. That is the tradition of the church and the service."

Performative and behavioural dispositions thus strengthen the location of religious performances and reflect embodied habitus.

Ritual performances then are highly organised performances that require a space that is likewise structured, controlling where and how the body moves in that location. Consequently the space of the church becomes a place for ritual performances because it is a place that can contain such practices. Additionally, the location of ritual performances is selected not only because the genre of performance requires a structured space, but also because the genre of performance precludes it being enacted in any other spaces. In fact, as I will also show in the next section, the performance makes

${ }^{47}$ See Figure 10 (p79) and Figure 12 (p83) to see contrast between locations and perceptions of sacred space. 
a sacred space for ritual performances through the cultural meanings that produce sacred space.

\section{Ritual performance of sacred space}

If the location of ritual performances in the CICC is chosen according to culturally constructed orientations of space, how are those locations and meanings of sacred space transmitted through ritual performance? Ritual performances create sacred space by distinguishing the location of Sunday worship from all other profane spaces. For example, hymns 'consciously establish' sacred space (Chidester \& Linenthal 1995) and set aside a space as sacred for the duration of ritual performances by the meanings communicated through songs. Every Sunday service, the first hymn sung is always the "Introit":

“313 Tune: CP 223, S.22

P cr I. Tapu, tapu, tapu to Iehova, Kua ki te ao nei i toou na kaka;

Tapu, tapu, tapu, te Atua ora, Tei Iakoe te mana e te au.
Translation of Introit

"Sacred, Sacred, Sacred Jehovah,

The adoring words of this world rise to your glory; Sacred, Sacred, Sacred, God of life You embody the mana and the rule." ${ }^{48}$

- H. Bond James" (Cook Islands Christian Church 1968)

As one informant told me "People understood what "tapu" meant because they already had a word for it" so they knew that they were singing about a place with mana (Field notes, 25 April 2010). The words of the hymn then, are an overt recognition that the space into which the ekalesia has entered is sacred. The space is not only set aside as tapu through performance, this performance also re-establishes and reinforces the sacredness of the space on a weekly basis. By calling attention to the sacredness of space at the start of each session for worship, all further behaviour and performance in that location is regulated within the period of the ritual. Therefore the Introit serves a dual purpose: it reminds ekalesia that they are in a sacred, ritual space and it marks the commencement of the ritual performance.

48 Translated with the help of Associate Professor Jeff Sissons, Victoria University of Wellington. 
Additionally, ritual performance in the CICC places an emphasis on the spoken word. The oral nature of performance can be just as powerful as images because spoken words evoke images and things in the world. The manner in which something is said or performed can also create associations in the minds of the hearer (Bowen 1998). Therefore singing as a congregation, singing the Lord's Prayer, and reciting Bible verses in unison these practices poetically produce sacred space by uniting individuals in a collective performance of ritual with others in the congregation. The performance also makes one aware that the sacred has been materialised in the architecture of the church. In particular, collectively singing as a congregation creates and amplifies the perception that a space is sacred because the aural power and sound of traditional hymns are impossible to replicate by one singer and they cannot be replicated in other places that do not have the same acoustics as churches do (Hale 2007). The ritual performance of Sunday worship then, is most powerful and sacred in limited spaces that can contain the collective performance of hymns.

However, non-traditional actions and behaviours can become part of ritual performance simply because the location in which they are performed sacralizes that action. Ordinarily in the sacred spaces of the church only the 'traditional' hymns, imene tuki, may be sung with no musical accompaniment, whereas in the semi-profane spaces outside of the church such as church halls, it is acceptable to sing 'modern' hymns for worship (including modern instruments like guitars and drums and dancing). One interviewee noted however that:

Interviewee 3: "The churches only allow a keyboard inside, not guitars. I don't mind if they say that though because on the keyboard you have everything on it so you can program it to include guitar too" (laughs)

Interviewee 2: "I don't think they know that." (more laughter)

Although in this instance the accompaniment with imene tuki and Sunday youth services are both a keyboard and "modern" musical instrument, what 
distinguishes one performance as sacred and "traditional" (i.e. imene tuki) compared to another (i.e. Sunday youth services), is the fact that the performance is enacted within a space that is already perceived as sacred. In this sense the sacred authorises particular practices because of location.

In conclusion, the concept of spatiality of performance helped to explain the process through which the location of Sunday worship is chosen for the historical and poetic reasons mentioned in Chapters One and Two. The notion of ritual performance of sacred space helped to reveal how the meanings transmitted through the performance also reinforce those poetic distinctions of space mentioned in Chapter Two. However, it is the momentum that the spatiality of performance and the performance of sacred space create through their relationship with one another that is also significant. Through the enactment and restriction of particular actions and behaviours and through reinforcing the sacredness of meanings performed in the location of the church they put into motion a process of continuity and constancy: an ongoing production and reproduction of sacred space through ritual performance.

\section{Nuku: A theatrical performance}

Not much literature has been written about Nuku. However, Nuku pageants are an extremely important part of the Cook Islands calendar ${ }^{49}$. Their purpose is to commemorate the arrival of the Gospel and the 'pioneering history of Christianity' in the Cook Islands. It is a day of remembrance for the faithful and an affirmation of how Christianity has shaped nationhood and the identity of the Cook Islands. The national Gospel Day is on the $26^{\text {th }}$ of October, the day that the London Missionary Society first set foot in the nation in 1821. In addition, each island has a separate Gospel Day celebration indicating when missionaries first arrived and

49Following Graag (2010), I make a distinction here between the $N u k u$ as a pageant that is held annually to celebrate Gospel Day and Nuku as a play based on a Biblical story that is performed in the Nuku pageant. 
preached at each island - Rarotonga's Gospel Day is the $25^{\text {th }}$ of July when Papehia first arrived in 1823.

The Nuku pageant gathers the community together through collective participation in theatrical performance ${ }^{50}$. It is hosted by each ekalesia "once every six years in Rarotonga in an anti-clockwise rotation around the island. In both the Northern and Southern Cook islands, villages host the Nuku in a similar rotation." (Graag, 2010: 11). The most immediate and visible spatial distinction is the way that the ekalesia and performers are seated according to which church parish they belong to. Each parish is distinguishable by its marquee with a flag displaying the church's name as well as by the distinct costumes worn by each church during their performance (Figure 13). The six churches line two opposing sides of the field while the ariki and mataiapo,, church leaders, and government officials make up the third side of the stage in the middle. The Nuku pageant starts with speeches by both traditional leaders and by senior members of the CICC. There are prayers and the importance of the CICC in converting an island to Christianity as well as the importance of the church in today's society is mentioned.

50 Originally, participation in Nuku pageants was not limited to just the Cook Islands Christian Church. In the past other denominations have participated and there are often calls for other Christian churches to take part for it is about the celebration of Christianity in the Cook Islands, not the denominations itself that is deemed important (Cook Islands News, 2000, 25 July; 2000, 27 October; 2007, 7 December). 


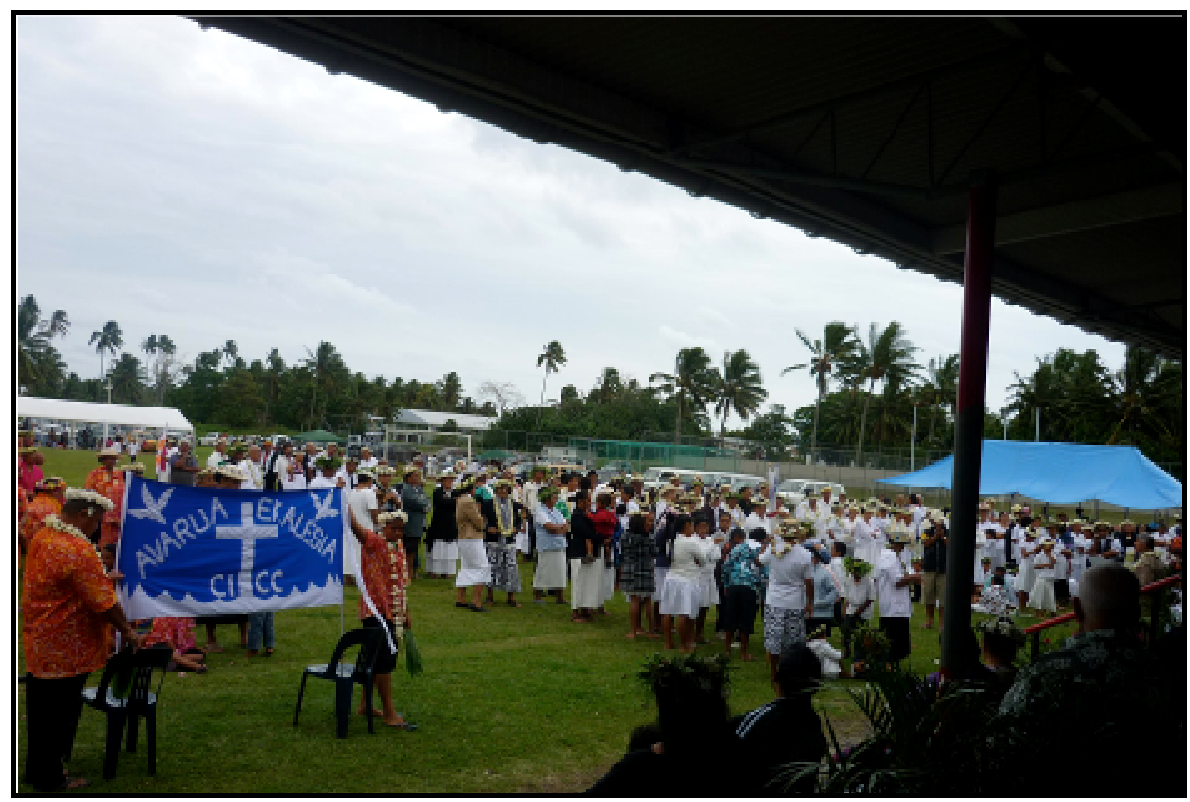

Figure 13: The performers from each CICC ekalesia line up before the ariki and mataiapo before the $\mathrm{Nuku}$ pageant begins.

The Nuku plays themselves are a spectacle of singing and dancing. The plays are earnest stories punctuated by bursts of laughter and physical displays of comedy that are often accentuated by props. For example boats are pulled around the field to show long voyages (Figure 14), fake limbs when cannibalism and deaths are involved, "Rambo looking warriors as soldiers" riding motorbikes, and even a replication of New York's burning twin towers have been used in the past - to the horror of many tourists (Cook Island News 2001, 24 July; 2003, 28 October; 2006, 27 October). Popular themes include adapting Biblical stories to address the issues facing the world and the Cook Islands today, commemorating the arrival of the Gospel in Rarotonga, as well as commemorating the countless 'South Seas pastors' who have taken the Gospel across Oceania ${ }^{51}$. Nuku pageants are theatrical performances that have truly been adapted to a local Cook Islands setting.

\footnotetext{
${ }^{51}$ Takamoa Theological College, situated next to the Avarua Cook Islands Christian Church, was in fact the first Theological College to be established in the Pacific (in 1839). Consequently there is a rich history of Cook Island missionaries, many of whom helped to spread the Gospel to other Pacific nations and who are rightly celebrated during Nuku (Cook Islands Christian Church n.d.).
} 


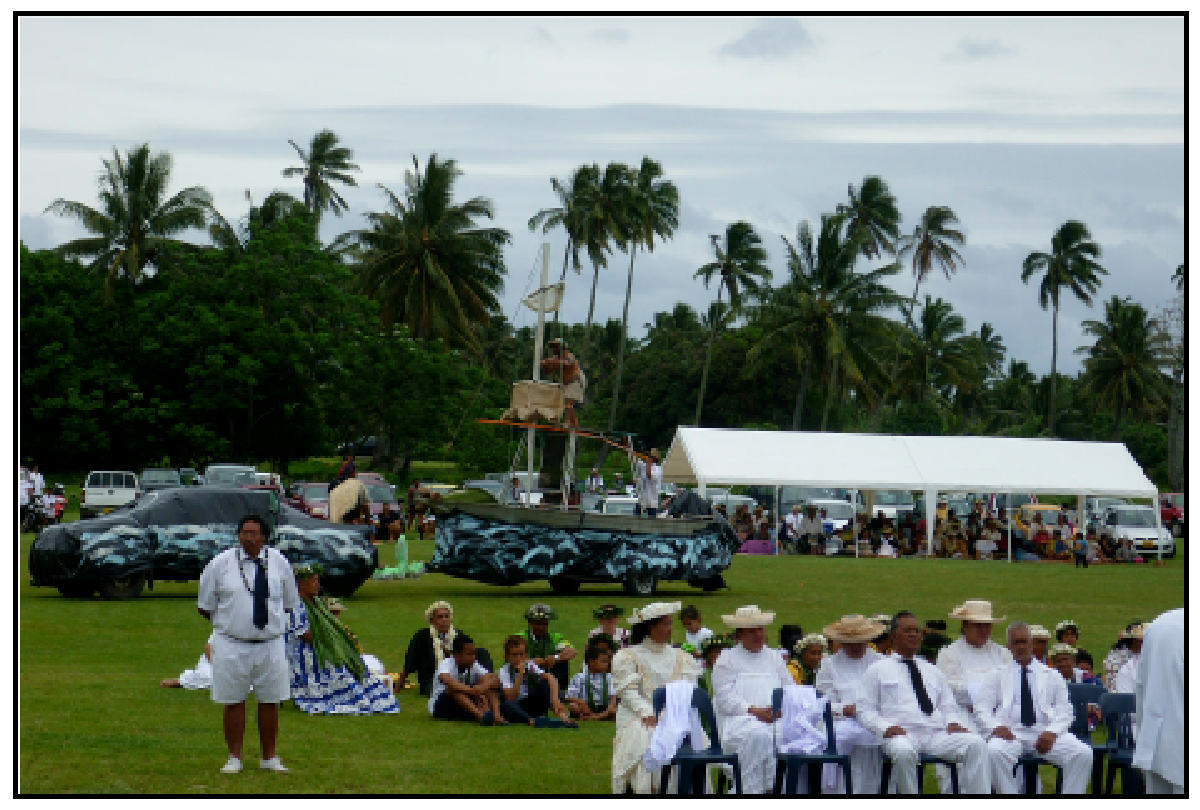

Figure 14: One of the props used at the 2010 Gospel Day celebrations. Performers wait as a boat with a "heathen" is pulled along the sports field. The boat shows the journey of Cook Islands missionaries who spread the gospel to the South Seas.

\section{The spatiality of theatrical performance}

In contrast to Sunday worship, the $N u k u$ pageants are normally held in a space near the church but not within it. But why does this genre of performance require a place set aside that is profane, rather than sacred? Of course due to the scale and theatrics of these religious performances it is necessary that they are enacted in an open, profane place. More importantly, the purpose of theatrical performance is often cyclical, they re-perform cultural events (in the case of $N u k u$, the arrival of the Gospel in the Cook Islands), and the performances allow for a break from cultural norms while ultimately reinforcing them ${ }^{52}$.

It is significant that $N u k u$ pageants are performed in places that are used for other purposes and functions than as exclusively a place for worship (E.g. a sports field). This both allows and accentuates the profane location and the inversion of sacred meanings in theatrical performances. For example, hula dancing and 'modern' musical instruments such as guitars

\footnotetext{
52 The meanings and cyclical characteristics of Nuku performances are very similar to what Marshall Sahlins termed "mythopraxis" (1985)
} 
become an accepted part of Nuku plays, along with ordinarily traditional elements of ritual performance such as singing hymns. Additionally, the expression of humour within ordinarily solemn religious stories is accepted I was told by one informant of a Nuku play where Moses' parting of the "red sea" became a humorous event because the water pressure on the hose was not correct. The dramatic parting of the red sea became a dribble (Field notes 30 April 2010, Graag 2010).

So, the locations of theatrical performances are large and open; they have no fixed boundaries allowing actions within that space to be fluid, nonpermanent, and non-traditional. Indeed, much like the liminal phases of rites and theatrical performances, the location itself is non-permanent, profane and "in-between" (Turner 1986). Therefore, the purpose and content of $N u k u$ performances require a profane location for them to be enacted in order for values of sacredness and spatial orientations to be played with, inverted, and communicated to the congregation. However, I will show in the next section that although the location of theatrical performances may be profane, the meanings transmitted through $N u k u$ pageants are not. Rather, Nuku continue to reinforce spatial and cultural values of the sacred by teaching Christian doctrines and behaviour as well as highlighting spatial orientations of the sacred and profane.

\section{Theatrical performance of sacred space}

Although theatrical performances are a different genre to ritual performances, both sacralize space by drawing attention to spatial orientations of the sacred/profane. In the case of Nuku pageants, awareness of the sacred/profane comes about through the behaviours enacted within performances, the location of performers and the audience, as well as through the meanings communicated in Nuku plays.

Firstly, the genre of theatrical performance allows behaviours ordinarily prohibited within sacred space to be enacted with traditional, ritual 
behaviour. For example, as mentioned earlier in relation to the spatiality of theatrical performances, $N u k u$ plays often include ritual practices such as hymn singing that are performed alongside non-Christian behaviour such as hula dancing (Figure 15).

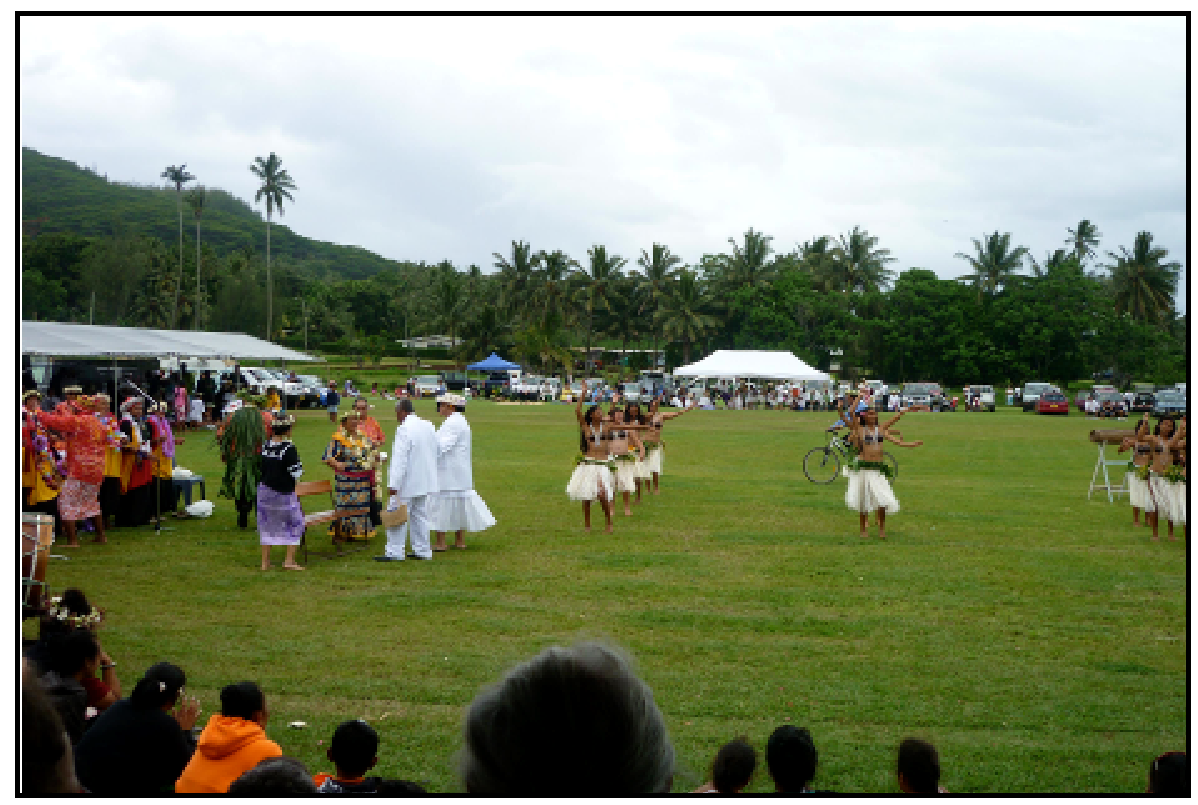

Figure 15: Hula dancing is performed in one of the Nuku plays at the 2010 Gospel Day celebrations. The dancing symbolised the journey of a missionary to and from different Pacific islands.

Secondly, the theatrical performances communicate the spatial orientations and cultural constructions of space mentioned in the Introduction and Chapter One through the location of the actors and audience. The social structures that I mentioned in the previous chapters - the tamaua relationship between orometua and traditional leaders, between the CICC congregation and orometua, between the CICC congregation and traditional leaders, as well as the social structures of the congregation - all find expression in how and where theatrical performances are enacted. 


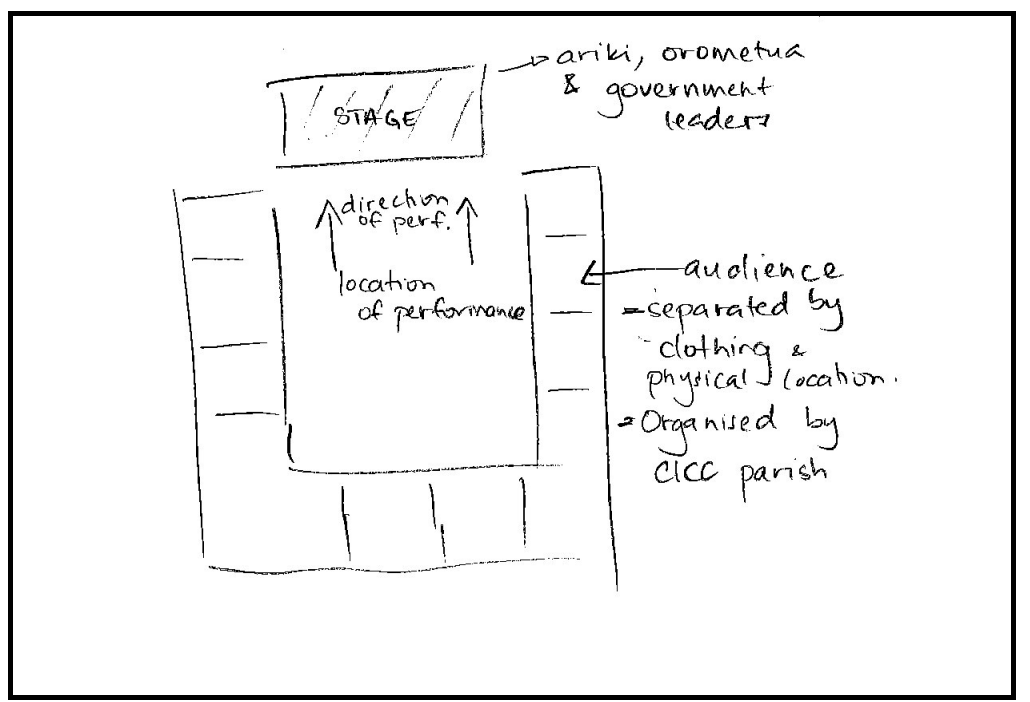

Figure 16: Diagram of spatial distinctions at Gospel Day (Nuku pageants). (Field notes, October 2010)

As the above diagram shows (figure 16), the social and spatial organisation present in every $\operatorname{church}^{53}$, such as the spatial separation between each village within a CICC parish and the distinguished location of traditional leaders from the rest of the ekalesia, is re-performed on a larger national scale. Likewise the spatial distinction of traditional leaders in the CICC church is replicated in the profane space of theatrical performances. While everyone can see and hear Nuku plays and engage with the performance through their reactions and responses, the actors themselves direct the $N u k u$ plays towards the main stage where titled and church leaders sit. Because ariki and mataiapo were instrumental in ushering in the conversion to Christianity, the religious performance recalls the conscious construction and control of sacred spaces by performing specifically to them ${ }^{54}$.

Furthermore, although the congregation takes over the role of performer and leader during Nuku plays, the orometua continue to reinforce their role as expert ritual practitioners within profane space. For example, before each $N u k u$ pageant begins the orometua lead an opening prayer and service, bible reading, sermon and hymn relocating elements of the sacred,

\footnotetext{
${ }^{53}$ See Figure 8 for the social-spatial organization of CICC churches (pg 72).

${ }^{54}$ See Chapters One and Two for a description of the tamaua relationship and how it is physically manifested in the architecture of the CICC church.
} 
ritual performance into the profane. Only once these ritual performances, led by the ritual practitioner, have been completed can the performance of a liminal, theatrical play begin. Therefore, despite the location of theatrical performances in a profane place, the powerful gaze of the church and traditional hierarchy continues outside of the church space ensuring that sacred spatial and behavioural values are recalled in theatrical performances.

Thirdly, Nuku pageants are a "public display of a society's central meaningful elements" (Beeman 1993: 380, emphasis added). So while the narrative of $N u k u$ plays can be historical or Christian moral dramas, what makes them meaningful for Cook Islanders is the fact that they have become localized Christian Cook Islands dramas. By localizing the performance to a Cook Islands context, the cultural values and meanings communicated through $N u k u$ plays reflect the spatial orientations and behavioural orientations of Cook Islands sacred space that I discussed in Chapter Two ${ }^{55}$.

On the one hand the Nuku plays often reference the Cook Islands as a spatial hub outside of which all behaviours are profane and 'modern'. The plays show how these modern behaviours are negatively influencing the Christian space and morals of the Cook Islands. For example the Arorangi ekalesia in 2003, to illustrate the theme of "Good against Evil", used current events in the world to demonstrate parallels with behaviour in the Cook Islands. The performance included songs about diseases such as AIDS, SARS and diseases specific to the Cook Islands - diabetes, heart disease and hypertension; displaying the Israeli-Palestine conflict over land claims; and to the disbelief of many tourists in the audience a portrayal of $9 / 11$ with cardboard twin towers and people jumping from windows onto mattresses below (Graag, 2010; Cook Islands News 28 October 2003).

Graag (2010) also gives another example of a Christian drama adapted to a Cook Islands context. She describes a Nuku by the Nikao ekalesia in which they used the story of Adam and Eve with the temptation

\footnotetext{
${ }^{55}$ See Figure 10 (pg 78) and Figure 12 (pg 82) for a description of the spatial and behavioural orientations in the Cook Islands Christian Church.
} 
of alcohol instead of an apple to demonstrate the decline of Christian and social values even in a place like the Cook Islands which has been described as a kingdom of heaven on earth (basiliea). By drawing parallels between a Biblical story and the lives of Cook Islanders, the audience recognises the transgression of Christian morals, and "the familiarity of a condition that everyone suffers from at some point, and the recognition that it is happening in such a perfect place" (Graag, 2010: 14).

On the other hand, the meanings communicated through $N u k u$ draw attention to a sacred spatial and behavioural orientation that radiates out from the Cook Islands. This is shown through the stories of the many missionaries in Cook Islands history - from those who brought the Gospel to the Cook Islands to those orometua who spread the Gospel in the Pacific. Regardless, of the profane location and narratives of performance, both themes of $\mathrm{Nuku}$ plays position the sacred spatial and behavioural reference point of the CICC church as triumphant over profane and un-Christian behaviour. Missionaries always succeed in converting heathens and there is an acceptance of Christian doctrines and behaviour.

The sacred spatial and behavioural reference point of the CICC church is also sacralized through a broader cultural performance. The Nuku is hosted each year on Rarotonga by one of the six Ekalesia in an anticlockwise rotation (Graag 2010). I suggest that this circulation around the island is a deeper cultural performance in which a national identity and Christian identity is unified through collective performance and participation. Although each CICC parish is demarcated symbolically by sitting in their own area and through dress, they are also part of a greater spatial orientation. Through visiting each other, being present in the same space, and the friendly competition of celebrating and performing the same event, a Rarotongan as well as Christian connection is established. The Nuku then creates a sense of spatial totality for both the island and Cook Islanders, as well as presenting a totality of a Christian nation. In addition I would argue that the Nuku is a cultural re-performance. The rotation between the churches on Rarotonga enacts the much earlier spatial performance of Tangiia's trek around 
Rarotonga when he established the traditional marae on the island. In a sense the $N u k u$, symbolises and re-performs not only the creation of a nation at the contact of Christianity, it also re-performs the spatial parallels with the preChristian marae, reconstituting a new spatial history.

In summary, the location of theatrical performances are chosen because the purpose, content, and liminal nature of $N u k u$ pageants likewise require an in-between, profane space. Because $N u k u$ pageants are typically performed in a profane space, inversions of sacred ritual behaviour as well as inversions between the roles of ritual practitioner, social leaders, and the audience are deemed acceptable. Although the location and roles of theatrical performances are different to ritual performances, the Nuku plays often reinforce the same socio-spatial organisation as well as sacred spatial and behavioural orientations that are produced through ritual performance. In fact, giving a regular outlet for traditional and cultural norms to be played with in a controlled setting renews social cohesion and social control. Moreover religious performances extend the meanings of sacred space beyond the immediate location of CICC churches to everyday, profane ones because the performances "reflect back to color the individual's conception of the established world of bare fact" (Geertz 1993: 119).

\section{Conclusion}

As I have shown in this chapter, a performance framework illustrates the spatial framework at work in the context of Cook Islands Christianity. The theatrical performances $(\mathrm{Nuku})$ and ritual performances (Sunday worship) while both expressing ideas of the Gospel, are embodied and transformed in a very different manner due to the different spaces in which they are performed (see Figure 17): 


\begin{tabular}{|c|ccc|}
\hline Location & Church & $\leftarrow \rightarrow$ & $\begin{array}{c}\text { Non-church space (e.g. sport } \\
\text { field) }\end{array}$ \\
\hline $\begin{array}{c}\text { Perception of } \\
\text { space }\end{array}$ & Sacred space & $\leftarrow \rightarrow$ & Sacred/Profane space \\
\hline Practice & $\begin{array}{c}\text { Traditional } \\
\text { practices/meanings } \\
\text { transmitted through } \\
\text { ritual performance }\end{array}$ & $\leftarrow \rightarrow$ & $\begin{array}{c}\text { Traditional practices/meanings } \\
\text { transmitted through theatrical } \\
\text { performance }\end{array}$ \\
\hline
\end{tabular}

Figure 17: Diagram of performances in correlation to spatial and behavioural orientations

However, although the practices within the CICC can be implicit or explicit, ritual or theatrical, what emerged in this chapter is that religious performances are united in that they all require and produce sacred space (Chidester \& Linenthal 1995; Holloway 2003; Knott 2005a). As seen in the spatiality of performance, religious performances require spaces specifically set aside for them according to the manner in which the performance is enacted. This spatial distinction of religious performance is necessary in order to give those performances meaning for the ekalesia and community. Secondly, as shown in performing sacred space, religious performances concurrently produce sacred space through the cultural themes and values about sacred space that are communicated via performances. What was also clear is that the spatiality of performance and the performance of sacred space exist in a reciprocal relationship with one another. Religious performances create sacred space through meanings, but these locations and buildings also take on autonomy of their own (Jones 1993). The sacredness of the location determines the genre of religious performance that is carried out within it and thus the meanings that are communicated about that place. This then, is the dialectic of performance.

One other theme which emerged is that the performance of sacred space draws upon the previous dialectics of spatial production. First, religious performances enact a poetic production of sacred space. As Eliade recognized, rituals and performance produce and reinforce the subjective experience and spatial distinctions of the sacred/profane (Eliade 1987). This 
is because just as architecture materializes the sacred, so too does performance reinforce those spatial orientations discussed in Chapter Two. Performances involve spatialization of the body and embodiment of the awareness of the sacred by "manipulat[ing] basic spatial distinctions between up and down, right and left, inside and outside, and so on, that necessarily revolve around the axis of the living body." (Chidester \& Linenthal, 1995: 10). It is these practices that bring about religious revelation and awareness of spatial orientations and distinctions (Bowen 1998). This can be said to be the performance of poetic space.

Second, religious performances enact a political production of sacred space. This is because religious performances are part of the fabric of that conscious spatial construction that I mentioned in Chapter One (Chidester \& Linenthal 1995). Therefore, religious performances make visible the invisible structures and processes of poetic space and political space. Additionally, although physical action is central to ritual, such performances are ordered by the overlying structures that are placed on those performances. For example, rituals are built up to become increasingly invariable and complex over time and so the "generational' or historical influence upon the correct rules for embodied action leaves little room for embodied generation and potentialities of practice. In many ways we are left in a situation where the body performs a 'repetition of regulatory norms' ... slighting the performativity of embodiment to 'make a difference' or differentiate”. (Holloway 2003:19631964). In other words, the body is ordered by inscribing discourses of religion and power on practices and place. As a result, how individuals experience, practice, and reproduce the sacred is culturally ordered - this is the performance of political space.

I shall now turn to examining how the performance of political space and the performance of poetic space produce a framework for understanding sacred space in the Cook Islands. 


\section{Chapter 4: Discussion}

The three main chapters of this thesis, the politics of space, the poetics of space, and the performance of space may seem like disparate modes of spatial production. However in light of my original research question 'in what manner do social constructions and subjective constructions of space interact to produce sacred space in the Cook Islands?' it was necessary to analyse the same topic (i.e. sacred space), from different perspectives in order to bring to light how space is produced.

The first two chapters in this thesis analysed sacred space from established theoretical perspectives. Chapter One applied the various paradigms of politics of space - the politics of property, the politics of (social) exclusion, the politics of exile and the politics of position - to the historical event where graves in the Avarua Cook Islands Christian Church were destroyed. I showed that the control and construction of space by certain social groups was negotiated and transformed through narratives of power, history, tradition, authenticity of authority, and social structures.

Chapter Two, likewise, applied the existing model of poetics of space - revelation (heirophany), feelings of awe (numinous), and establishment of spatial and behavioural orientations around the sacred - to the CICC churches. I illustrated that although the poetic production of space is highly subjective, the poetic comes to manifest itself in the world through symbols and material structures. In turn the architectural and social markers of cultural meanings attributed to physical space reinforce the subjective production of the sacred. In other words, the sacred is represented through symbols in the church building which are in turn embodied and internalized through practice. 
Finally in Chapter Three, I introduced a new model for analysing the production of sacred space which I called the performance of space. I presented the performance of space as two aspects - the spatiality of performance (the location of religious performances) and the performance of the sacred (namely the meanings transmitted through performance). By comparing and contrasting different genres of religious performance (i.e. ritual vs. theatre and spectacle), the spatial orientation of sacred space can be understood. The outcome of this analysis showed that performances produce a unique Cook Islands cosmology of sacred and profane space through an inter-connected process. Performance and practices are produced and defined by sacred space, they are authorised and limited, prescribed and restricted by it. Similarly, the special characteristics of sacred space are constructed, shaped, allowed and restricted by performance and practices. In other words performances create space but also give expression to the politics and poetics of space in a complexly inter-related process.

So what conclusions can be drawn from the three modes of (sacred) spatial production? I argue that two vital points emerged which can contribute to current theories about how sacred space is produced. Firstly, I claim that although the politics, poetics, and performance of space may seem like disparate modes of spatial production, they are in fact part of the same process. As this thesis has shown, there is a complexity, interrelationship, and mutual dependence between the modes of production (Wilson 1993). The relationship between the modes of spatial production occurs because the politics, poetics, and religious performance of space are all mediated through social practices (Knott 2005a; Lefebvre 1991; MacDonald 2002). Consequently the production of sacred space moves beyond the traditional dichotomous models of sacred vs. profane or subjective vs. objective. Instead, a spatial triad emerges (Figure 18) wherein space is produced via politics (social structures), poetics (subjective perception), and performance (cultural embodiment): 


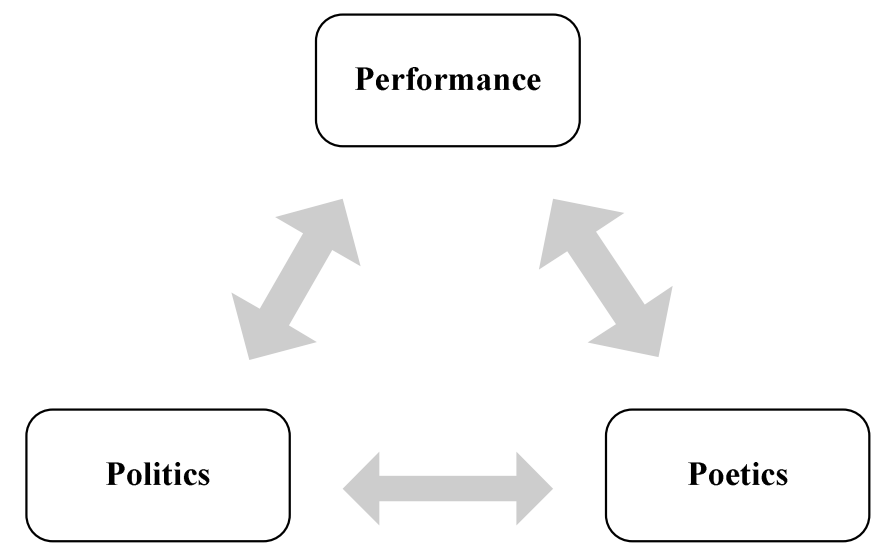

Figure 18: Diagram of modes of spatial production

The idea that spatial production is more than a dichotomous relationship between the subjective and objective is very similar to the spatial theory postulated by Henri Lefebvre. There are 'representations of space' which is a space conceived and conceptualized through knowledge and ideology (politics of space). 'Representational space' is the space of everyday life; experienced and perceived through the symbols of its inhabitants and users. It is a passively experienced space dominated by the representations of space (poetics of space). Lastly there is 'spatial practice'. These are practices which enact society's space ensuring social cohesion and spatial competence (performance of space). To some extent spatial practices are closely related to representational space because practice arises out of perceptions of space (Knott 2005a; Lefebvre 1991; Merrifield 1993). In light of the massive influence that Henri Lefebvre has had on many disciplines in understanding social spaces, it is surprising that his work has not been applied beyond urban spaces to other concepts of space (Knott 2005a; MacDonald 2002). Therefore, applying this triad to the production of sacred space takes up the work of Kim Knott (2005a) who calls for a greater application of social production of space to religious places. I too believe that there is a real value in applying Lefebvre's model to sacred space because the sacred/profane, like any other space, is produced through social and cultural processes. 
Although I have heeded Knott's approach to expand the existing models of sacred spatial production by considering social practices (2005a), I would go further than Lefebvre and claim, based on my analysis, that there is one extra element that needs to be added to the spatial triad. This extra but crucial element is context. Within this ethnographic study, it was the unique context of historical cultural narratives of Christianity along with the social relationships between traditional leaders and the CICC that tied the modes of production together. For example, the tamaua relationship between traditional leaders and orometua informed how spaces were constructed and who was in control of that process. Additionally the tamaua relationship was materialized symbolically throughout the architecture and physical structure of sacred spaces. Likewise, the pre-Christian cosmology of sacred and profane space influenced how spaces were consciously constructed and internalized through practices.

So, because the politics, poetics, and performance of space are interconnected and expressed through the context of social processes I would add context as a fourth element of spatial production (Brace et al 2006; Lefebvre 1991). As a result, the triad of spatial production in the Cook Islands looks something like this (Figure 19):

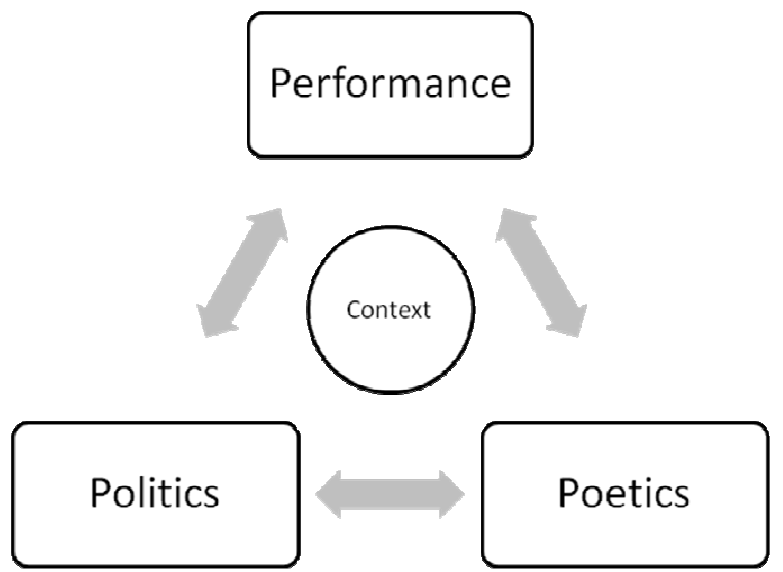

Figure 19: Diagram of modes of spatial production in the Cook Islands

Naturally, within other cultural contexts this model of the social production of sacred space (Figure 19) will differ. Unlike the Cook Islands, where 
historical narratives and relationships have become strongly rooted in social structures, the contexts which inform the social production of sacred space may not so clearly expressed in other cultures. Therefore, although performance, politics, and poetics would remain as the key modes of spatial production, other future studies will require a close examination of social processes, space and performance in order to find the unique cultural context, discourse or narrative which binds the social production of sacred space together.

This leads to the second conclusion that can be drawn from this thesis. Because the politics and poetics of space reside in the realm of intangible structures and experiences, I argue that performance also contributes to a wider understanding of spatial production by allowing the invisible poetics of space and the untouchable politics of space to be manifested in tangible reality. Geertz noted that cultural performances "represent not only the point at which the dispositional and conceptual aspects of religious life converge for the believer, but also the point at which the interaction between them can be most readily examined by the detached observer" (Geertz 1993: 113). In other words, practice and performance become the lynchpin between the different modes of spatial production by illuminating the processes of spatial production. Consequently, performance is more than an analytical framework; it is also a useful methodological framework to explain the production of sacred space (Beeman 1993; Knott 2005a).

So, to answer the question that I began with, I claim that social constructions and subjective constructions of space interact to produce sacred through processes which occur simultaneously. The process of social and subjective construction of space is revealed, both theoretically and methodologically, through practices and performance. At a broader level, I advocate for space and the spatial model I have presented, as being an essential part of any future research. As I pointed out in an earlier paragraph, although the specifics of the spatial triad may have to be changed according to the cultural context in which it is applied, the three modes of spatial 
production (politics, poetics, and performance) continue to be a useful framework for understanding space. In particular, the application of the spatial triad to sacred space moves the study of religious space and place beyond the well trodden theoretical path of sacred/profane dichotomies into a new direction to understand sacred space. The spatial triad is more likely to capture and describe the social and spatial as "ceaselessly penetrative, complexly intertwined, and mutually constructive" (Wilson 1993: 76). 


\section{Glossary of terms}

akamanea - beautify

ara metua - ancient path

ara tapu - sacred path

ariki - paramount chief(s)

Arorangi - one of six parishes on Rarotonga

Avarua - one of six parishes on Rarotonga

Avatiu - sub-district of Avarua parish

basiliea - kingdom of heaven on earth

ekalesia - parish

imene apii sabati - western choir style hymns

imene tuki - traditional hymns

mana - power

marae - traditional meeting and sacred places

Maraerenga - sub-district of Avarua parish

mataiapo - sub-chief(s)

Matavera - one of six parishes on Rarotonga

Ngatangiia - one of six parishes on Rarotonga

Nikao - one of six parishes on Rarotonga

$N u k u$ - a pageant that is held annually to celebrate Gospel Day. Also a play

based on a Biblical story which is performed in the Nuku pageant

orometua - native missionaries/priests

pere pere - high notes sung in traditional hymns

Rarotonga - main and largest island in the southern grouping of the Cook Islands

rangatira - minor-chief(s)

Ruatonga - sub-district of Avarua parish

Takuvaine - sub-district of Avarua parish

tamaua - adopted child

tapere - sub-district(s) 
tapu - sacred

ta'unga - traditional Cook Islands priest

tiakono - deacon

Titikaveka - one of six parishes on Rarotonga

Tupapa - sub-district of Avarua parish

Tutakimoa - sub-district of Avarua parish 


\section{Bibliography}

Altizer, T. J. J. (1975). Mircea Eliade and the Dialectic of the Sacred (2nd ed.). Westport, CT: Greenwood Press.

Appadurai, A. (1981). The Past as a Scarce Resource. Man, New Series, 16(2), 201-219.

Arweck, E., \& Keenan, W. J. F. (Eds.). (2006). Materializing Religion: Expression, Performance and Ritual. Aldershot, Hampshire: Ashgate Publishing Limited.

Aune, M. B. (1996). The Subject of Ritual: Ideology and Experience in Action. In M. B. Aune \& V. DeMarinis (Eds.), Religious and Social Ritual: Interdisciplinary Explorations (pp. 147-173). New York: State University of New York Press.

Beeman, W. O. (1993). The Anthropology of Theatre and Spectacle. Annual Review of Anthropology, 22, 369-393.

Bennett, C. (1996). In search of the sacred: Anthropology and the study of religions. London and New York: Cassell.

Bernard, H. R. (2006). Research Methods in Anthropology: Qualitative and Quantitative Approaches (Fourth Edition.). Lanham, MD: Altamira Press.

Bernard, H. R., \& Ryan, G. W. (2010). Analyzing Qualitative Data: Systematic Approaches. Thousand Oaks, California: Sage Publications.

Blain, J., \& Wallis, R. (2007). Sacred Sites: Contested Rites/Rights. Eastbourne: Sussex Academic Press.

Bourdieu, P. (1970). The Berber house or the world reversed. Social Science Information, 9(2), 151-170.

Bourdieu, P. (1989). Social Space and Symbolic Power. Sociological Theory, 7(1), 14-25.

Bowen, J. R. (1998). Religions in Practice: An Approach to the Anthropology of Religion. Boston: Allyn and Bacon.

Brace, C., Bailey, A. R., \& Harvey, D. C. (2006). Religion, place and space: a framework for investigating historical geographies of religious identities and communities. Progress in Human Geography, 30(1), 28-43.

Braun, V., \& Clarke, V. (2006). Using thematic analysis in psychology. Qualitative Research in Psychology, 3, 77-101. 
Brown, D. (2004). God and Enchantment of Place: Reclaiming Human Experience. Oxford, UK: Oxford University Press.

Budgett, J. (2007). Coral Architecture of the Cook Islands (Master of Architecture). University of Auckland, Auckland.

Buse, J., \& Taringa, R. (1995). Cook Islands Maori dictionary (B. Biggs \& R. Moeka'a, Eds.). Cook Islands: Ministry of Education, Govt. of the Cook Islands.

Campbell, M. (2002a). History in Prehistory: The Oral Traditions of the Rarotongan Land Court Records. The Journal of Pacific History, 37(2), 221238.

Campbell, M. (2002b). Ritual Landscape in Late Pre-Contact Rarotonga: A Brief Reading. Polynesian Society, 111(2), 147-169.

Cannell, F. (2006). The Anthropology of Christianity. In F. Cannell (Ed.), The Anthropology of Christianity (pp. 1-50). Durham and London: Duke University Press.

Carmichael, D. L., Hubert, J., Reeves, B., \& Schanche, A. (Eds.). (1994). Sacred Sites, Sacred Places. London and New York: Routledge.

Chidester, D., \& Linenthal, E. T. (1995). Introduction. In D. Chidester \& E. T. Linenthal (Eds.), American Sacred Space (pp. 1-42). Bloomington, Indiana: Indiana University Press.

Chin-Hong, C. (2007). Mircea Eliade's Dialectic of Sacred and Profane and Creative Hermeneutics. In B. Rennie (Ed.), The International Eliade (pp. 197-205). New York: State University of New York Press.

Collier, Jr., J., \& Collier, M. (1999). Visual Anthropology: Photography as a Research Method (6th ed.). Albuquerque: University of New Mexico Press.

Conquergood, D. (1989). Poetics, play, process, and power: The performative turn in anthropology. Text and Performance Quarterly, 9(1), 82-88.

Conquergood, D. (1991). Rethinking Ethnography: Towards a Critical Cultural Politics. Communication Monographs, 58, 179-194.

Cook Islands Christian Church. (n.d.). Cook Islands Christian Church: An introduction to Takamoa (pamphlet). Rarotonga, Cook Islands.

Cook Islands Christian Church. (1968). Te Au imene Ekalesia na te Cook Islands Christian Church: ei akapaapaa anga $i$ te Atua i te Rarotonga (6th ed.). London, Fakenham \& Reading: Cox \& Wyman Ltd. 
Cook Islands News. (2000, 25 July). Gospel day for all - churches urged to be more active. Cook Islands News. Rarotonga, Cook Islands.

Cook Islands News (2000, 27 October). Nuku free for all Christian denominations. Cook Islands News. Rarotonga, Cook Islands.

Cook Islands News. (2001, 24 July). Gospel Reenactment gets a little more real. Cook Islands News. Rarotonga, Cook Islands.

Cook Islands News. (2003, 2 April). Avarua CICC to consult "aronga mana." Cook Islands News. Rarotonga, Cook Islands.

Cook Islands News. (2003, 4 April) Letters to the Editor. Cook Islands News, p. 4. Rarotonga, Cook Islands.

Cook Islands News. (2003, 5 April) Letters to the Editor. Cook Islands News, p. 4. Rarotonga, Cook Islands.

Cook Islands News. (2003, 7 April) Letters to the Editor. Cook Islands News, p. 4. Rarotonga, Cook Islands.

Cook Islands News. (2003b, 7 April). Work stops on graves in church yard. Cook Islands News. Rarotonga, Cook Islands.

Cook Islands News. (2003, 9 April). Grave destruction halted. Cook Islands News. Rarotonga, Cook Islands.

Cook Islands News. (2003, 10 April). Work to continue in graveyard today. Cook Islands News. Rarotonga, Cook Islands.

Cook Islands News. (2003, 11 April). Grave complaint laid with police. Cook Islands News. Rarotonga, Cook Islands.

Cook Islands News. (2003b, 11 April). No resolution at Ngati Makea meeting. Cook Islands News. Rarotonga, Cook Islands.

Cook Islands News. (2003, 19 April). Historic Places committee re-established. Cook Islands News. Rarotonga, Cook Islands.

Cook Islands News. (2003, 24 May). Church minister and MP to court. Cook Islands News. Rarotonga, Cook Islands.

Cook Islands News. (2003, 31 May). Criminal charges dropped in CICC graveyard case. Cook Islands News. Rarotonga, Cook Islands.

Cook Islands News. (2003, 20 June). Laying charges in CICC case, "an act of desperate people." Cook Islands News. Rarotonga, Cook Islands.

Cook Islands News. (2003, 23 June). Graveyard talks fail. Cook Islands News. Rarotonga, Cook Islands. 
Cook Islands News. (2003, 28 October) 9/11 horror portrayed in nuku pageant. Cook Islands News. Rarotonga, Cook Islands.

Cook Islands News. (2006, 27 October) Hundreds packed the Ngatangiia CICC grounds for the annual Gospel Day festival yesterday. Cook Islands News. Rarotonga, Cook Islands.

Cook Islands News. (2007, 7 December). Island bans new churches at Gospel day celebration. Cook Islands News. Rarotonga, Cook Islands.

Cook Islands News Weekend. (2003, 28 June). In the name of beautification. Cook Islands News Weekend. Rarotonga, Cook Islands.

Cook Islands Statistics Office. (2006). Cook Islands 2006 Census of Population and Housing: Analytical Report. Rarotonga, Cook Islands: Cook Islands Statistics Office.

Corrigan, J. (2009). Spatiality and religion. In B. Warf \& S. Arias (Eds.), The Spatial Turn: Interdisciplinary Perspectives (pp. 157-172). Abingdon: Routledge.

Cresswell, T. (2004). Place: A short introduction. Oxford: Blackwell Publishing.

Davies, C. A. (2008). Reflexive Ethnography: A guide to researching selves and others (2nd ed.). London and New York: Routledge.

Davies, D. (2003). Christianity. In J. Holm \& J. Bowker (Eds.), Sacred place (pp. 33-61). London and New York: Continuum.

de Certeau, M. (1988). The practice of everyday life. California: University Of California Press.

DeWalt, K. M., \& DeWalt, B. R. (2011). Participant Observation: A Guide for Fieldworkers (2nd ed.). Lanham, MD: Altamira Press.

Doorly, M. (2003). The Destruction of Sacred Space. Latin Mass Society of England \& Wales.

Durkheim, E. (1915). The Elementary Forms of the Religious Life. London: George Allen \& Unwin.

Eliade, M. (1987). The Sacred and the Profane: The Nature of Religion. Florida: Harcourt Books.

Eller, J. D. (2007). Introducing Anthropology of Religion. New York: Routledge.

Engelke, M., \& Tomlinson, M. (Eds.). (2007). The limits of meaning: case studies in the anthropology of Christianity. Berghahn Books. 
Evans, M. T. (2003). The Sacred: Differentiating, Clarifying and Extending Concepts. Review of Religious Research, 45(1), 32-47.

Eyring, M. (1998). How Close is Close enough?: Reflections on the Experience of doing Phenomenology. In K. deMarrais (Ed.), Inside Stories: Qualitative Research Reflections (pp. 139-150). Mahwah, NJ \& London, UK: Lawrence Erlbaum Associates.

Foucault, M. (1986). Of Other Spaces. (J. Miskowiec, Trans.)Diacritics, 16(1), $22-27$.

Fowler, B. (1996). An Introduction to Pierre Bourdieu's “Understanding.” Theory, Culture \& Society, 13(2), 1-16.

Garrett, J. (1985). To Live Among the Stars: Christian Origins in Oceania. Geneva \& Suva, Fiji: World Council of Churches \& Institute of Pacific Studies, University of the South Pacific.

Geertz, C. (1993). Religion as a cultural system. In C. Geertz (Ed.), The Interpretation of Cultures: Selected Essays (pp. 87-125). London: Fontana Press.

Gell, A. (1988). Technology and Magic. Anthropology Today, 4(2), 6-9.

Gell, A. (1998). Art and Agency: An Anthropological Theory. New York and Oxford: Clarendon Press.

Gell, A. (1999). The Technology of Enchantment and the Enchantment of Technology. In E. Hirsch (Ed.), The Art of Anthropology: Essays and Diagrams (pp. 159-186). New Jersey: The Athlone Press.

Gibbs, G. R. (2007). Analyzing Qualitative Data. London: Sage Publications.

Gill, W. (1856). Gems from the Coral Islands: Incidents of Contrast Between Savage and Christian Life of the South Sea Islanders. London: Ward and Co.

Gilson, R. P. (1980). The Cook Islands, 1820-1950. Wellington, New Zealand: Victoria University Press in association with the Institute of Pacific Studies in the University of the South Pacific.

Gobo, G. (2008). Doing Ethnography. (A. Belton, Trans.). London: Sage Publications.

Gragg, J. E. (2010). Seeing the funny side: Focusing on Cook Islands humour in the experience of the religious pageant Nuku (Master in Art and Design). Auckland University of Technology, Auckland. 
Griffin, J. (1827). Memoirs of Capt. James Wilson: containing an account of his enterprises and sufferings in India, his conversion to Christianity, his missionary voyage to the south seas, and his peaceful and triumphant death. (Second American Edition.). Portland: James Adams, Jr.

Gunson, N. (1978). Messengers of Grace: Evangelical Missionaries in the South Seas 1797-1860. Oxford, UK: Oxford University Press.

Hale, S. E. (2007). Sacred Space, Sacred Sound: The Acoustic Mysteries of Holy Places. Wheaton, Illinois: Quest Books.

Halgren Kilde, J. (2008). Sacred Power, Sacred Space: An Introduction to Christian Architecture and Worship. Oxford: Oxford University Press.

Hallam, E., \& Hockey, J. (2001). Death, Memory and Material Culture. Oxford and New York: Berg.

Hauser-Schäublin, B. (2004). The Politics of Sacred Space: Using conceptual models of space for socio-political transformations in Bali. Bijdragen tot de Taal-, Land- en Volkenkunde, 160(2/3), 283-314.

Hendrickson, C. (2008). Visual Field Notes: Drawing Insights in the Yucatan. Visual Anthropology Review, 24(2), 117-132.

Henkel, R. (2005). Geography of Religion - Rediscovering a Subdiscipline. Hrvatski Geografski Glasnik, 67(1), 5-25.

Henry, H. (2003). "Christianity created a Nation": Arrival of the Gospel and the Early Mission Years in the Cook Islands. Auckland: Sovereign Pacific Publishing Company.

Holloway, J. (2003). Make-believe: spiritual practice, embodiment, and sacred space. Environment and Planning A, 35(11), 1961-1974.

Holloway, J., \& Valins, O. (2002). Editorial: Placing religion and spirituality in geography. Social \& Cultural Geography, 3(1), 5-9.

Holm, J., \& Bowker, J. (Eds.). (2003). Sacred Place. London: Continuum.

Hubbard, P., Kitchin, R., \& Valentine, G. (Eds.). (2004). Key Thinkers on Space and Place. London: Sage Publications.

Ingold, T. (2009). Against Space: Place, Movement, Knowledge. In P. Wynn Kirby (Ed.), Boundless Worlds: An Anthropological Approach to Movement (pp. 29-43). Oxford and New York: Berghahn Books.

Jain, J. (2010). Place, Space, and Representation: Transporting Sacred Geographies. BioScope: South Asian Screen Studies, 1(1), 91-101. 
Jonassen, J. T. M. (2004). Polynesia in Review: Issues and Events, 1 July 2002 to 30 June 2003: Cook Islands. The Contemporary Pacific, 16(1), 146-153.

Jones, L. (1993). The Hermeneutics of Sacred Architecture: A Reassessment of the Similitude between Tula, Hidalgo and Chichen Itza, Yucatan, Part I. History of Religions, 32(3), 207-232.

Jones, L. (2000). The Hermeneutics of Sacred Architecture: Experience, Interpretation, Comparison (Vols. 1-Two, Vol. One). Cambridge, MA: Distributed by Harvard University Press for Harvard University Centre for the Study of World Religions.

Knott, K. (2005a). The Location of Religion: A Spatial Analysis. London: Equinox Publishing.

Knott, K. (2005b). Spatial theory and method for the study of religion. Temenos, 41(2), 153-184.

Knott, K. (2009). From locality to location and back again: A spatial journey in the study of religion. Religion, 39, 154-160.

Kokot, W. (2006). Culture and Space - anthropological approaches. Key Concepts in Social Anthropology: Space. Presented at the Swiss Graduate Programme in Ethnology/Anthropology, Basel.

Kong, L. (1990). Geography and religion: trends and prospects. Progress in Human Geography, 14, 355-371.

Kong, L. (1993). Negotiating conceptions of "sacred space": a case study of religious buildings in Singapore. Transactions of the Institute of British Geographers, New Series, 18(3), 342-358.

Kong, L. (2001). Mapping "new" geographies of religion: politics and poetics in modernity. Progress in Human Geography, 25(2), 211-233.

Kong, L. (2002). In Search of Permanent Homes: Singapore's House Churches and the Politics of Space. Urban Studies, 39(9), 1573-1586.

Kong, L. (2004). Religious Landscapes. In J. S. Duncan, N. C. Johnson, \& R. H. Schein (Eds.), A companion to cultural geography (pp. 365-381). Malden, MA: Blackwell Publishing. Retrieved from

Kong, L. (2010). Global shifts, theoretical shifts: Changing geographies of religion. Progress in Human Geography, 34(6), 755-776.

Kramer, B. (2005). Protestant Civic Art: A Thesis Submitted to the Graduate School of the University of Notre Dame in Partial Fulfillment of the 
Requirements for the Degree of Master of Architecture (Master of Architecture). University of Notre Dame, Indiana.

Lambek, M. (Ed.). (2008). A Reader in the Anthropology of Religion (2nd ed.). Oxford: Blackwell Publishing.

Lane, B. C. (1988). Landscapes of the Sacred: Geography and Narrative in American Spirituality. Baltimore: The Johns Hopkins University Press.

Lange, R. (1997). The Origins of the Christian Ministry in the Cook Islands and Samoa. Christchurch: Macmillan Brown Centre for Pacific Studies.

Lawrence, D. L., \& Low, S. M. (1990). The Built Environment and Spatial Form. Annual Review of Anthropology, 19, 453-505.

LeCompte, M. D., \& Schensul, J. J. (1999). Analyzing and Interpreting Ethnographic Data. Walnut Creek, California: Altamira Press.

Lefèbvre, H. (1991). The Production of Space. (D. Nicholson-Smith, Trans.). Oxford, UK: Wiley-Blackwell.

Lee, J., \& Ingold, T. (2006). Fieldwork on Foot: Perceiving, Routing, Socializing. In S. Coleman \& P. Collins (Eds.), Locating the Field: Space, Place and Context in Anthropology (pp. 67-86). Oxford: Berg.

Leeuw, G. van der. (1986). Religion in Essence and Manifestation. (J. E. Turner, Trans.). Princeton, New Jersey: Princeton University Press.

Low, S. M., \& Lawrence-Zúñiga, D. (Eds.). (2003). The anthropology of space and place: locating culture. Oxford, UK: Blackwell Publishing.

MacDonald, F. (2002). Towards a spatial theory of worship: Some observations from Presbyterian Scotland. Social \& Cultural Geography, 3(1), 61-80.

MacDonald, M. N. (2003). Experiences of Place. Cambridge, MA: Harvard University Press.

Manning, P. (2008). Materiality and Cosmology: Old Georgian Churches as Sacred, Sublime, and Secular Objects. Ethnos, 73(3), 327-360.

Maretu, \& Crocombe, M. T. (1983). Cannibals and Converts: Radical change in the Cook Islands. Rarotonga, Cook Islands: University of the South Pacific in association with the Ministry of Education.

Mazumdar, S., \& Mazumdar, S. (1993). Sacred Space and Place Attachment. Journal of Environmental Psychology, 13, 231-242.

Merleau-Ponty, M. (1962). Phenomenology of Perception. (C. Smith, Trans.). London: Routledge \& Kegan Paul Ltd. 
Merrifield, A. (1993). Place and Space: A Lefebvrian Reconciliation. Transactions of the Institute of British Geographers, New Series, 18(4), 516531.

Merrihew Adams, R. (1995). Moral Horror and the Sacred. The Journal of Religious Ethics, 23(2), 201-224.

Niles, D. (2000). Polynesian Hymns in Papua: The Synthesis of a Christian Educational Tool and Local Creative Expression. Journal of International Development and Cooperation, 6(1), 145-158.

O’Dea, T. (1966). The Sociology of Religion. New Jersey: Prentice-Hall Inc.

O'Reilly, K. (2005). Ethnographic methods. London and New York: Routledge.

Ortner, S. B. (2006). Anthropology and Social Theory: Culture, Power, and the Acting Subject. Durham: Duke University Press.

Otto, R. (1923). The Idea of the Holy. (J. Harvey, Trans.). New York: Oxford University Press.

Outhwaite, W., \& Turner, S. P. (Eds.). (2007). The SAGE Handbook of Social Science Methodology. London: Sage Publications.

Pacific Islanders' Church. (1981). Pacific Islanders' Church: Hymnary. Auckland: J.E. Jenkins \& Co Ltd, Printers.

Pink, S. (2007). Doing Visual Ethnography: Images, Media and Representation in Research (2nd ed.). London: Sage Publications.

Prosser, J. (Ed.). (1998). Image-based Research: A Sourcebook for Qualitative Researchers. London: RoutledgeFalmer.

Prout, E. (n.d.). Memoirs of the life of the Rev. John Williams, missionary to Polynesia.

Rennie, B. (Ed.). (2006). Mircea Eliade: A Critical Reader. London: Equinox Publishing.

Rere, T. (1980). The Gospel Comes to Rarotonga. Australia: South Pacific Cultures Fund.

Rere, T. (1982). History of Rarotonga up to 1853.

Robben, A. C. G. M. (2004). Death and Anthropology: An Introduction. Death, Mourning, and Burial: A Cross-Cultural Reader (pp. 1-16). Oxford: Blackwell Publishing.

Sack, R. D. (1980). Conceptions of Space in Social Thought: A Geographic Perspective. London: Macmillan Press. 
Sahlins, M. D. (1985). Islands of History. London: Tavistock Publications.

Schieffelin, E. L. (2005). Problematizing Performance. In G. Harvey (Ed.), Ritual and Religious Belief: A Reader (pp. 124-138). New York: Routledge: Taylor \& Francis Group.

Shiner, L. E. (1972). Sacred Space, Profane Space, Human Space. Journal of the American Academy of Religion, 40(4), 425-436.

Siikala, J. (1991). 'Akatokamanava: Myth, History and Society in the Southern Cook Islands. Auckland: The Polynesian Society in association with the Finnish Anthropological Society, Helsinki.

Singer, M. (1972). When a Great Tradition Modernizes: An Anthropological Approach to Modern Civilization. New York, Washington, London: Praeger Publishers.

Sissons, J. (1989). The Seasonality of Power: The Rarotongan Legend of Tangiia. Journal of Polynesian Society, 98(3), 331-347.

Sissons, J. (1999). Nation and Destination: Creating Cook Islands Identity. Suva, Fiji Islands: Institute of Pacific Studies.

Sissons, J. (2007). From Post to Pillar: God-Houses and Social Fields in Nineteenth-Century Rarotonga. Journal of Material Culture, 12(1), 47-63.

Slough, R. J. (1996). "Let Every Tongue, by Art Refined, Mingle Its Softest Notes With Mine": An Exploration of Hymn-Singing Events and Dimensions of Knowing. In M. B. Aune \& V. DeMarinis (Eds.), Religious and Social Ritual: Interdisciplinary Explorations (pp. 175-206). New York: State University of New York Press.

Smith, J. Z. (2005). To Take Place. In G. Harvey (Ed.), Ritual and Religious Belief: A Reader (pp. 26-50). New York: Routledge: Taylor \& Francis Group.

Soja, E. W. (1980). The Socio-Spatial Dialectic. Annals of the Association of American Geographers, 70(2), 207-225.

Stillman, A. K. (1993). Prelude to a Comparative Investigation of Protestant Hymnody in Polynesia. Yearbook for Traditional Music, 25, 89-99.

Stirrat, R. L. (1984). Sacred Models. Man, New Series, 19(2), 199-215.

Strauss, A. L., \& Corbin, J. M. (1998). Basics of Qualitative Research: Techniques and Procedures for Developing Grounded Theory (2nd ed.). Thousand Oaks, California: Sage Publications. 
Swain, T., \& Trompf, G. (1995). The Religions of Oceania. London; New York: Routledge.

Syme-Buchanan, F. (n.d.). Mauke - South Pacific island gem. Escape: Magazine of the Cook Islands, (6).

Tomlinson, M. (2002). Sacred Soil in Kadavu, Fiji. Oceania, 72(4), 237-257.

Toren, C. (1988). Making the Present, Revealing the Past: The Mutability and Continuity of Tradition as Process. Man, New Series, 23(4), 696-717.

Toren, C. (2006). The Effectiveness of Ritual. In F. Cannell (Ed.), The Anthropology of Christianity (pp. 185-210). Durham and London: Duke University Press.

Turnbull, D. (2002). Performance and Narrative, Bodies and Movement in the Construction of Places and Objects, Spaces and Knowledges. Theory, Culture \& Society, 19(5/6), 125-143.

Turner, V. (1974). Dramas, Fields, and Metaphors: Symbolic Action in Human Society. Ithaca and London: Cornell University Press.

Turner, V. (1988). The Anthropology of Performance. New York: PAJ Publications.

Tyerman, D., \& Bennet, G. (1832). Journal of voyages and travels by the Rev. Daniel Tyerman and George Bennet, esq: Deputed from the London Missionary Society to visit their various stations in the South Sea Islands, China, India, etc between the years 1821 and 1829 (Vol. 2). Boston: Crocker and Brewster.

Tyler, S. (1986). Post-Modern Ethnography. In J. Clifford \& G. Marcus (Eds.), Writing Culture (pp. 122-140). Berkeley, California: University Of California Press.

Verdery, K. (2004). Dead Bodies Animate the Study of Politics. In A. C. G. M. Robben (Ed.), Death, Mourning, and Burial: A Cross-Cultural Reader (pp. 303-310). Oxford: Blackwell Publishing.

Warf, B., \& Arias, S. (Eds.). (2009). The Spatial Turn: Interdisciplinary Perspectives. New York: Routledge.

Williams, J. (1837). A Narrative of Missionary Enterprises in the South Seas Islands: With remarks upon the natural history of the Islands, origin, languages, traditions, and usages of the inhabitants. London: J. Snow. 
Wilson, D. (1993). Connecting Social Process and Space in the Geography of Religion. Area, 25(1), 75-76.

Wolcott, H. F. (2005). The Art of Fieldwork (2nd ed.). Walnut Creek, California: Altamira Press.

Yanow, D. (2006). How Built Spaces Mean: A Semiotics of Space. In D. Yanow \& P. Schwartz-Shea (Eds.), Interpretation and Method: Empricial Research Methods and the Interpretive Turn (pp. 349-366). New York: M. E. Sharpe.

Yeoh, B. S. A. (1991). The Control of "Sacred" Space: Conflicts over the Chinese Burial Grounds in Colonial Singapore, 1880-1930. Journal of Southeast Asian Studies, 22(2), 282-311.

Yorgason, E., \& della Dora, V. (2009). Geography, religion, and emerging paradigms: problematizing the dialogue. Social \& Cultural Geography, 10(6), 629-637. 